UNIVERSITY OF CALIFORNIA

COLLEGE OF AGRICULTURE

AGRICULTURAL EXPERIMENT STATION

BERKELEY, CALIFORNIA

\title{
ECONOMIC ASPECTS OF THE BEE INDUSTRY
}

\author{
EDWIN C. VOORHIES, FRANK E. TODD, \\ AND J. K. GALBRAITH
}

Results of a coöperative investigation conducted by the Pacific States Bee Culture Field Laboratory of the United States Department of Agriculture, Bureau of Entomology, and the California Agricultural Experiment Station

\author{
BULLETIN 555 \\ SEPTEMBER, 1933 \\ CONTRIBUTION FROM THE \\ GIANNINI FOUNDATION OF AGRICULTURAL ECONOMICS
}




\section{CONTENTS}

PAGE

Sumimary

Development of beekeeping

Early history

Beekeeping as a supplementary agricultural enterprise

Beekeeping as an avocation for urban dwellers

Specialization in beekeeping

Geographical distribution of beekeeping in the United States Honey districts

Floral sources of honey in the United States

Principal types of honey

Forms of honey produced

Honey grades and grading

California bee ranges and their utilization $r$

Belt I, south coast and chaparral belt . . . . . . . . . . . . . . . . 22

Belt II, Sacramento-San Joaquin belt _ . . . . . . . . . . . . . . . . . . $\quad . \quad 29$

Belt III, transmountain belt . . . . . . . . . . . . . . . . . . . 35

Belt IV, Bay region and cut-over redwood area . . . . . . . . . . . . . . 35

Distribution of beekeeping in California . . . . . . . . . . . . . . 37

Migratory beekeeping . . . . . . . . . . . . . . . . . . 38

Number of colonies per beekeeper in California . . . . . . . . . . . . 41

Honey production . . . . . . . . . . . . . . . . . . . . . . 42

United States . . . . . . . . . . . . . . . . . . . . . . . 43

California . . . . . . . . . . . . . . . . . . . . . . . . . . . . . . . . . . . . . 44

Territorial possessions of the United States . . . . . . . . . . . . 45

Seasonal production . . . . . . . . . . . . . . . . . . . . . . . . 46

Production per colony

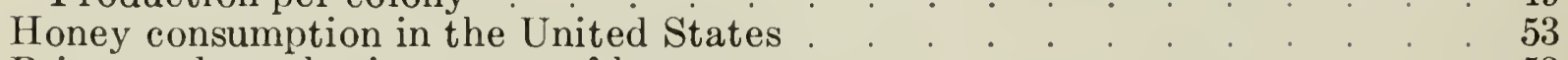

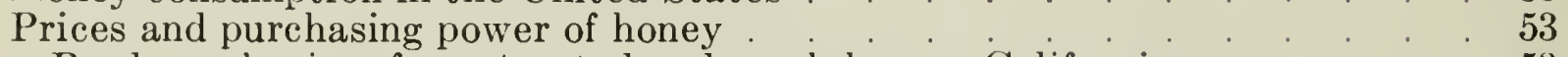

Producers' prices for extracted and comb honey, California . . . . . $\quad .53$

Retail prices . . . . . . . . . . . . . . . . . 57

Factors influencing the prices of California honey $\quad . \quad$. $\quad . \quad . \quad . \quad . \quad$. $\quad . \quad 59$

Domestic trade in honey . . . . . . . . . . . . . . . . . . . . 64

United States export trade in honey . . . . . . . . . . . . . . . . . 66

Importance of California exports .

Trend and distribution of California honey exports . . . . . . . . . . . . $\quad .67$

The German market . . . . . . . . . . . . . . . . 68

Competing countries in the German market _ . . . . . . . . . 70

Factors affecting German imports of United States honey in 1930 and 193171

Uses of honey in Germany and consumer preference . . . . . . . . . 74

I'uture status of the German market for California honey . . . . . . . . 74

The British market . . . . . . . . . . . . . . . . . . 74

Competing countries in the British market _ . . . . . . . . . . . . . $\quad$. 75

Use of honey in the United Kingdom and consumer preference . . . . . 78

Future status of the British market for California honey . . . . . . 78

'The world honey situation . . . . . . . . . . . . . . . . 79

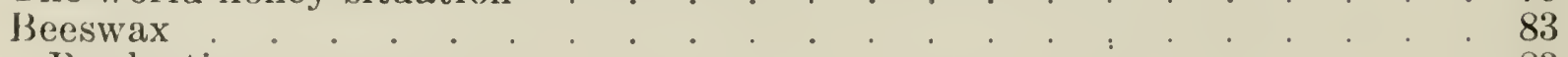

Production . . . . . . . . . . . . . . . . . . . . . . . . . . 83

Domestic beeswax prices . . . . . . . . . . . . . . . . . . . 86

Queen production . . . . . . . . . . . . . . . . . . . . . . . . . . . 93

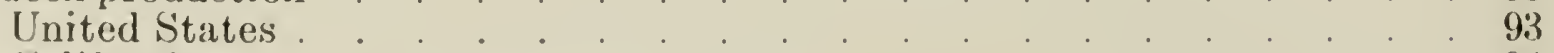

California . . . . . . . . . . . . . . . . . . . . . 94

Prices of California queen bees . . . . . . . . . . . . . . . . . . . . $\quad .98$

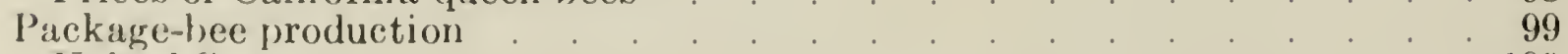

United States

Cislifornia . . . . . . . . . . . . . . . . . . . . 101

Renting bees for pollination . . . . . . . . . . . . . . . . . 103

Cost factors in honey and beeswax production . . . . . . . . . . . . . . 106

l' lurnover in the bee industry . . . . . . . . . . . . . . . . . 110

L coss of colonies in California . . . . . . . . . . . . . . . . . . . . . . . . 112

Arknowledgments . . . . . . . . . . . . . . . . . . . . . 116 


\section{Economic Aspects of the Bee Industry ${ }^{1,2}$}

EDWIN C. VOORHIES, ${ }^{3}$ FRANK E. TODD, ${ }^{4}$ AND J. K. GALBRAITH ${ }^{5}$

\section{SUMMARY}

Bee culture is one of the forty leading agricultural industries in California from the standpoint of annual returns to producers. Since beekeeping is an industry which must be spread over a rather wide area for the proper exploitation of honey plants, the value of its products and services is often overlooked.

Data showing honey production on farms are available in the United States census records. In California, however, probably one-third of the honey or less is produced on farms. The census records since 1860 for the country as a whole show that farm production of honey increased rapidly up to 1890. During the next two decades, 1890 to 1910, there was a marked decline in production, particularly in the areas east of the Mississippi River, but during the past decade farm production again increased. The territory west of the Mississippi River has been contributing a larger percentage of the country's total farm crop of honey, until, according to the 1930 Census, it produced about one-half of the farm crop. The number of farmers keeping bees has declined almost 25 per cent from 1900 to 1930 ; there was a somewhat similar decline in the number of colonies on farms. This decline of beekeeping on farms has taken place while specialization in beekeeping has been growing.

The weather probably has a greater effect on honey and wax production than on many other agricultural commodities. A noticeable relation exists between the cumulative rainfall over a series of years in California and the per-colony yield. Over the past two decades both yield of honey per colony and rainfall have declined. Other factors such as sunshine, temperature, and wind direction and velocity also play a part in influencing per-colony production.

1 Received for publication March 7, 1933.

2 Paper No. 39, the Giannini Foundation of Agricultural Economics. The bulletin was prepared by the Pacific States Bee Culture Field Laboratory of the United State Department of Agriculture Bureau of Entomology, and the Giannini Foundation of the University of California in coöperation. As a result of this work see also: Voorhies, Edwin C., Frank E. Todd, and J. K. Galbraith. Honey marketing in California. California Agr. Exp. Sta. Bul. 554:1-31. 1933.

3 Associate Professor of Agricultural Economics, Agricultural Economist in the Experiment Station, and Agricultural Economist on the Giannini Foundation.

4 Associate Apiculturist, Pacific States Bee Culture Field Laboratory of the United States Department of Agriculture Bureau of Entomology.

5 Research Assistant on the Giannini Foundation. 
In the apiculture industry of California has come an increasing differentiation between three more or less distinct groups: (1) farmers producing honey as a side line, (2) persons whose main enterprise is honey production-these usually conduct no other agricultural enterpriseand (3) persons whose main enterprise is the production of queen and package bees. The honey flows in both the utilized and unutilized bee districts of the state have been outlined in this bulletin so that the more specialized beekeeper may know how to avail himself of favorable locations for his enterprise. A knowledge of the flows in the state and in the entire country will assist all beekeepers in keeping informed of conditions which affect the prices of honey crops and enable them to gauge their own operations more closely. For example, if conditions surrounding the growth of sweet clover appear to be adverse to the production of honey over considerable areas in other states, some California beekeepers may find it possible to increase their production.

The most important factors influencing the price of honey are: (1) supply factors, (2) demand factors, and (3) the general price level. During the War period a strong demand for honey, stimulated in part by war-time restrictions on the use of sugar, sent honey prices to exceptionally high levels. With the decline in the general price level in subsequent years and the removal of restrictions on other sweets, honey prices have tended to lower levels.

Table honeys, such as orange, sage, and star thistle did not suffer as severe a price decline in post-war years as did honeys which are used to a considerable extent for manufacturing purposes, such as alfalfa and wild-flower honey. Apparently rather different influences are at work in determining the prices of the two general classes of honey. There are indications of a more elastic demand for the table honeys.

Table honeys remained somewhat above other foodstuffs in price until 1930 but have been relatively lower since that time. Producers' prices for honey dropped precipitously with the fall in general commodity prices in 1930,1931 , and 1932, but fell relatively less than the producers' prices for other farm commodities. It is important to note in this connection that production in 1930, 1931, and 1932 was below the level of previous years.

A factor contributing to depressed honey prices was the loss of foreign trade in this commodity. The United States and particularly ('alifornia has had, in recent years, an important export trade in honey, but this trade fell off greatly in 1930, 1931, and 1932. Germany and the United Kingdom have been by far the most important markets abroad, and California honey has been favorably regarded in both of these mar- 
kets. In 1932, Italy was the most important market for United States honey.

In the case of Germany, tariffs and replacement by lower-priced, lower-quality honey from other countries have combined with serious economic disorder to decrease greatly exports from California to that country during 1930 and 1931 and constitute obstacles to any immediate improvement. Exports to the United Kingdom have been better maintained but decreased purchasing power, Empire preferences, and the aggressive sales methods of New Zealand and Canada make the future prospect indefinite.

The chief competing countries in the German market are Cuba, Chile, Guatemala, and other countries in Central and South America and in the West Indies. The most important competitor's on the British market are the British Dominions of New Zealand and Canada and the colonies of the West Indies.

Hawaiian honey is shipped in sizable quantities to continental United States, between 1 and 2 million pounds being sent in some years. Algaroba is the chief Hawaiian honey and is used to a considerable extent in blends.

Accurate data on the ammual per-capita consumption of honey in the United States are nonexistent, but according to estimates it is less than 2 pounds and probably not greater than $11 / 2$ pounds. There is evidence of a higher cousumption in western United States. Consumption among the moderately well-to-do and wealthier classes is apparently higher than among those in less fortunate circumstances.

Compared with the pre-war period, domestic beeswax prices have descended to far lower levels than have honey prices. Since 1920 beeswax has come into the United States in quantities from three to five times as large as during the pre-war period. In addition there has been an increasing competition from certain vegetable and mineral waxes, many of which are lower priced than beeswax. The fall of the Orthodox Eastern Church in Russia following the War and Revolution released large supplies of beeswax which formerly found a market in that country.

Over the past decade the relation between the prices or articles that the farmer buys and the products that he sells has been decidedly unfavorable to him. 'The same situation has prevailed in the honey and wax industry. Both labor and equipment costs liave remained at relatively higher levels than have either prices of honey or wax.

Since the War, pronounced changes have come about in the location of the queen-producing areas of the United States, the California and the southern districts becoming of far greater consequence than heretofore 
in this branch of beekeeping. The rise of the package-bee industry in these same districts has still further accentuated the development of queen-breeding in these areas and in Texas. Within California there has been a pronounced shift, the Sacramento Valley coming to occupy an outstanding place in queen and package-bee production. This has been due largely to the character of the honey flows in this area. California now occupies the foremost position in queen-breeding in the western United States, shipping its products to the eleven western states and three most westerly provinces of Canada.

It is impossible to evaluate in dollars and cents the services of the honeybee in pollination of fruit trees and other plants. Well-informed persons believe that in California such services are of greater value than the honey and wax produced within the state.

\section{DEVELOPMENT OF BEEKEEPING}

Early History.-IIoney was probably the chief sweet of early Greece and Rome. It is likely that it occupied this place in Europe for a considerable period because sugar cane was not cultivated in Spain until about a thousand years ago. Sugar was one of the first crops which Spain cultivated in the New World. It was long regarded as a luxury until improvements in refining made possible its commercial use as a cheap source of sweet. On the other hand, honey declined in importance because little progress was made towards cheaper methods of production until the middle of the Nineteenth Century, when the movable frame hive was invented in the United States, and methods of quantity production began to be developed.

The honeybee (Apis mellifica L.) is an immigrant to the United States. T'he German, or black, race was brought into New England before $1638 .{ }^{6}$ "Black bees reached West Florida not later than 1763, Kentucky in 1780, New York in 1793, west of the Mississippi in 1797-California in 1853."7 In 1859 or 1860 the Italian bee, which has displaced the black bee almost entirely, was introduced into eastern United States, and thence into California in $1860 .^{8}$

Since 1860, bee culture in the United States has developed along three lines: (1) as a supplementary agricultural enterprise; (2) as an avocation for urban dwellers; and (3) as a specialized vocation. The development has not been continuous or clear-cut.

\footnotetext{
6 Gates, Burton N. Miscellaneous papers on apiculture: VIJ. Beckeeping in Massachusetts. U. S. Dept. Agr. Bur. Ent. Bul. 75:81-83. 1911.

T Phillips, F. F. Beekeeping. 490 p. The Macmillan Co., New York. 1928.

8 Itarbison, J. S. Beckecpers directory. p. 390-392. H. H. Bancroft and Company, San Francisco, California. 1861.
} 
Beekeeping as a Supplementary Agricultural Enterprise.--The production of honey on farms grew steadily from 1859 to 1899, increasing 300 per cent, but since the latter date there is evidence of a considerable decline. In 1859 practically the entire farm crop was produced east of the Mississippi River; by 1879 about 80 per cent, and by 1899 about 50 per cent. The latter distribution has been maintained ever since.

Farm beekeeping for the country as a whole has been declining since the beginning of the present century, as is evidenced by a decrease in honey production on farms, in the number of farmers keeping bees, and in the number of colonies. 'The greatest relative declines have occurred in the areas east of the Mississippi and in Texas. The percentage of farms in the United States on which bees were kept, as indicated by the Census, declined from 12.3 in 1900 to 7.3 in 1930 (1910, 9.2; 1920, 8.4).

A heavy decline is likewise to be noted in total number of colonies kept on farms, although the changing of dates for taking the Census makes actual figures on number of colonies of little value. This decline in farm beekeeping can be attributed in part to (1) the inroads of disease, which have necessitated more labor for apiary maintenance; (2) a decline in honey plants in some areas; (3) arsenical spraying in fruit areas; (4) inroads which farming, grazing, and forest fires have made on the bee ranges of native plants, such as sage in California and native plants in Texas $;^{9}$ and (5) unattractive returns in the bee industry in recent years.

The decrease in the numbers of bees on farms is creating pollination problems. So acute has the situation become in some fruit-growing and clover-seed regions that farmers are either renting bees during blossom time from bee specialists or purchasing package bees for pollination purposes.

Beekeeping as an Avocation for Urban Dwellers. - No accurate data are available on beekeeping in urban centers. Those dealing with the problem of disease eradication report that numerous urban people possess 1 to 10 colonies. In Los Angeles, Oakland, and San Francisco there are several thousand such beekeepers. While beekeeping by urban dwellers stimulates interest in bee culture, production is usually so low that from the standpoint of volume it does not greatly affect the honeymarket situation.

Specialization in Beekeeping.--Prior to 1850 few persons followed bee culture as a vocation. Bees were kept in box hives, and were killed to obtain the honey. Honey was sold locally, as either chunk or strained honey. Primitive methods prevented quantity production.

9 Contribution from: the Texas Agricultural Rescarch Iaboratories. Beekeepers' Item 16:222-223. 1932 . 
Specialization in bee culture followed the inventions of the movable frame hive (Langstroth, 1851), comb foundation (Mehring, 1857), and the extractor, (Hruschka, 1865). The application of these improvements reduced production costs and encouraged quantity production. Since 1880 specialization has grown steadily, particularly west of the Mississippi and has not only made up for the decreases in farm production, but has probably been responsible for a doubling of the total annual honey tonnage in the first three decades since 1900. During the World War period a particularly rapid growth in specialized beekeeping was stimulated.

An important phase of specialization has been the commercial production of queens and package bees. Queen production received considerable impetus soon after the turn of the century following the discovery that the Italian race was more resistant to European foulbrood than the then common German black race. Epidemics of this disease were followed by requeening with Italian stock. Another closely related phase of specialization is the shipping of package bees. This was stimulated diuring the War period as a means of rapid expansion of bee culture to meet the increased honey demand, and, while practiced by a limited number of individuals, has assisted materially in stock improvement.

Since the bee industry depends on sources outside its control for its raw products (pollen and nectar), its development has been linked rather intimately with agriculture in general. The early development was in areas having native plants valuable as nectar sources, and it is believed that these are being fully utilized, except perhaps in the southern district (fig. 1). Developments since 1900 have been closely associated with eultivated plants such as alfalfa, sweet clover, oranges, cotton, and also with certain weeds that have followed cultivation. Future developments may be expected to follow rather closely changes that take place in the distribution and acreages of cultivated plants. 


\section{GEOGRAPHICAL DISTRIBUTION OF BEEKEEPING IN THE UNITED STATES}

Bee culture is practiced generally over the United States (fig. 1) and in areas with widely different climates and flora, e.g., Wyoming and Florida. This wide distribution and lack of concentration is perhaps one

Honey-Producing Districts of the United States and Estimated Anyual Production, 1928-1931

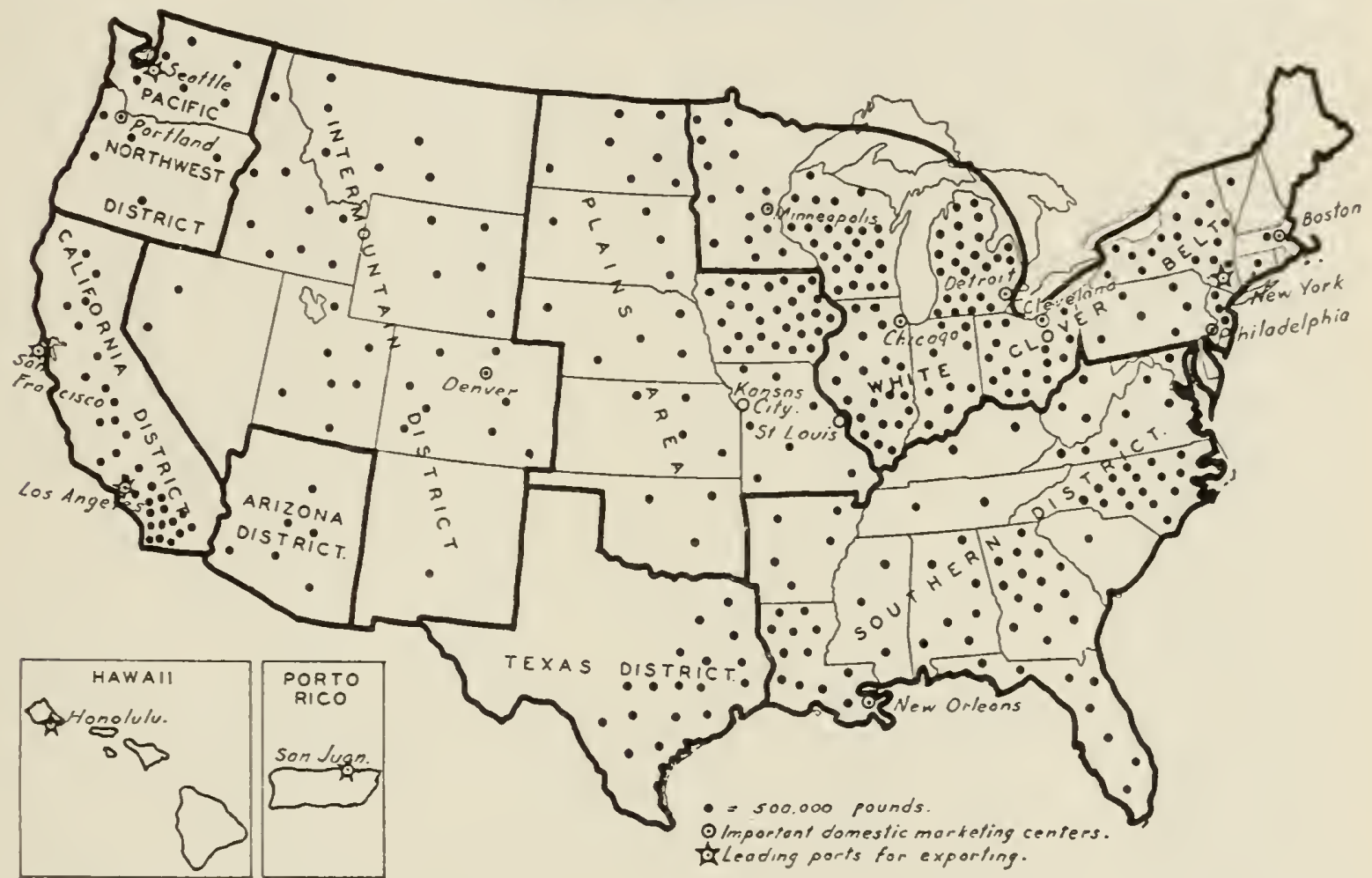

Fig. 1.-Continental United States is dirided into eight honey-producing districts. More or less distinct types of honey are to be found in each. California is the leading honey-producing state in the United States, but the most concentrated production is in the White Clover Belt. Honey production is rather generally dis tributed over the entire countrr, although the production in the western states is somewhat scattered. (Data on districts based on those outlined in: U. S. Dept. Com. Bur. Foreign and Dom. Com. The honey trade in the United States May 1, 1926, rerised Feb. 1, 1928, Dec. 1, 1929. [Mimeo.] Production data from: U. S. Dept. Agr. Bur. Agr. Econ. Honer. No. 325. 1931. Semimonthly mimeographed report.)

of the factors working against the better organization of markets. Unfortunately, no accurate data on distribution are available, because of the limitations of the census data. ${ }^{10}$

10 The enumerations of the United States Census are not representative of the bee industry. Many, perhaps the majority, of specialized beekeepers who as a group produce about 60 per cent of the honey crop, and also a group of considerable size owning less than 6 colonies are not enumerated under the present census definitions. In the past the census date has raried from decade to decade, being taken sometimes when winter losses are at a maximum and other times when at a minimum. This destrors the comparability of colony numbers as reported by different censuses. Data taken during the period of increase, March to August, are not comparable between districts, because the time when increase is made varies considerably between districts.

A census taken with a colony count, as of January 1, and with ownership of bees a sufficient qualification for inclusion, would probably obviate the above difficulties. 


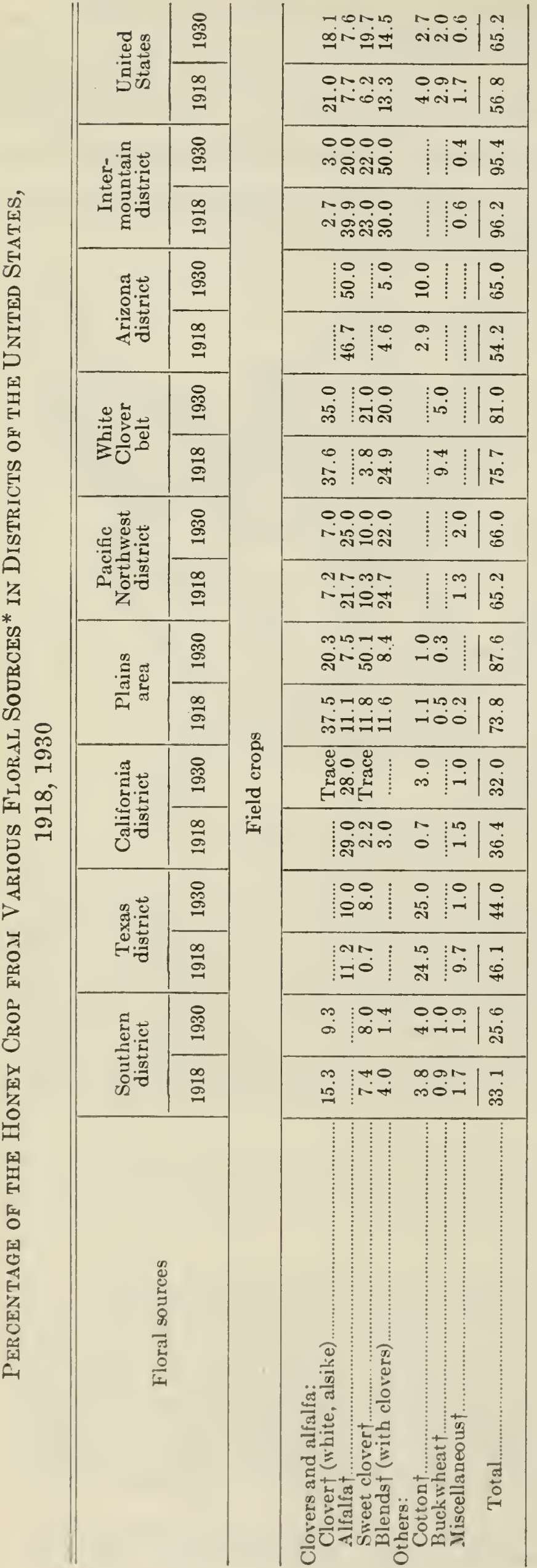

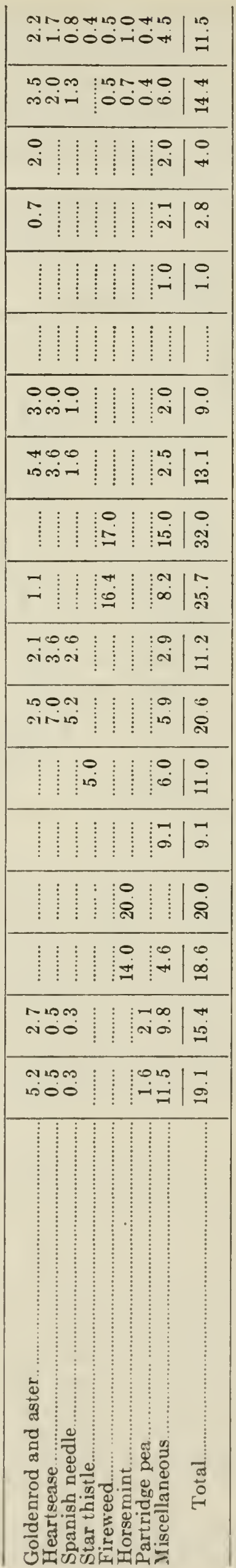

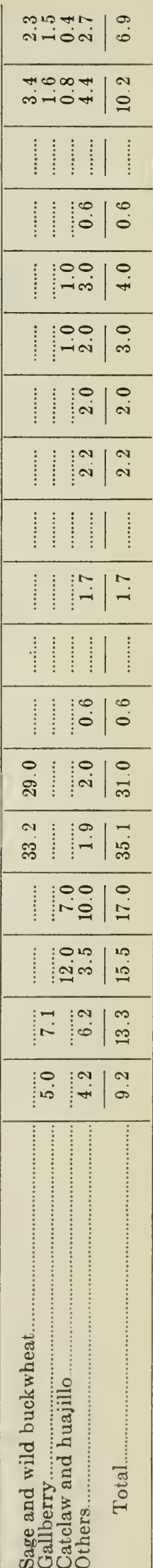




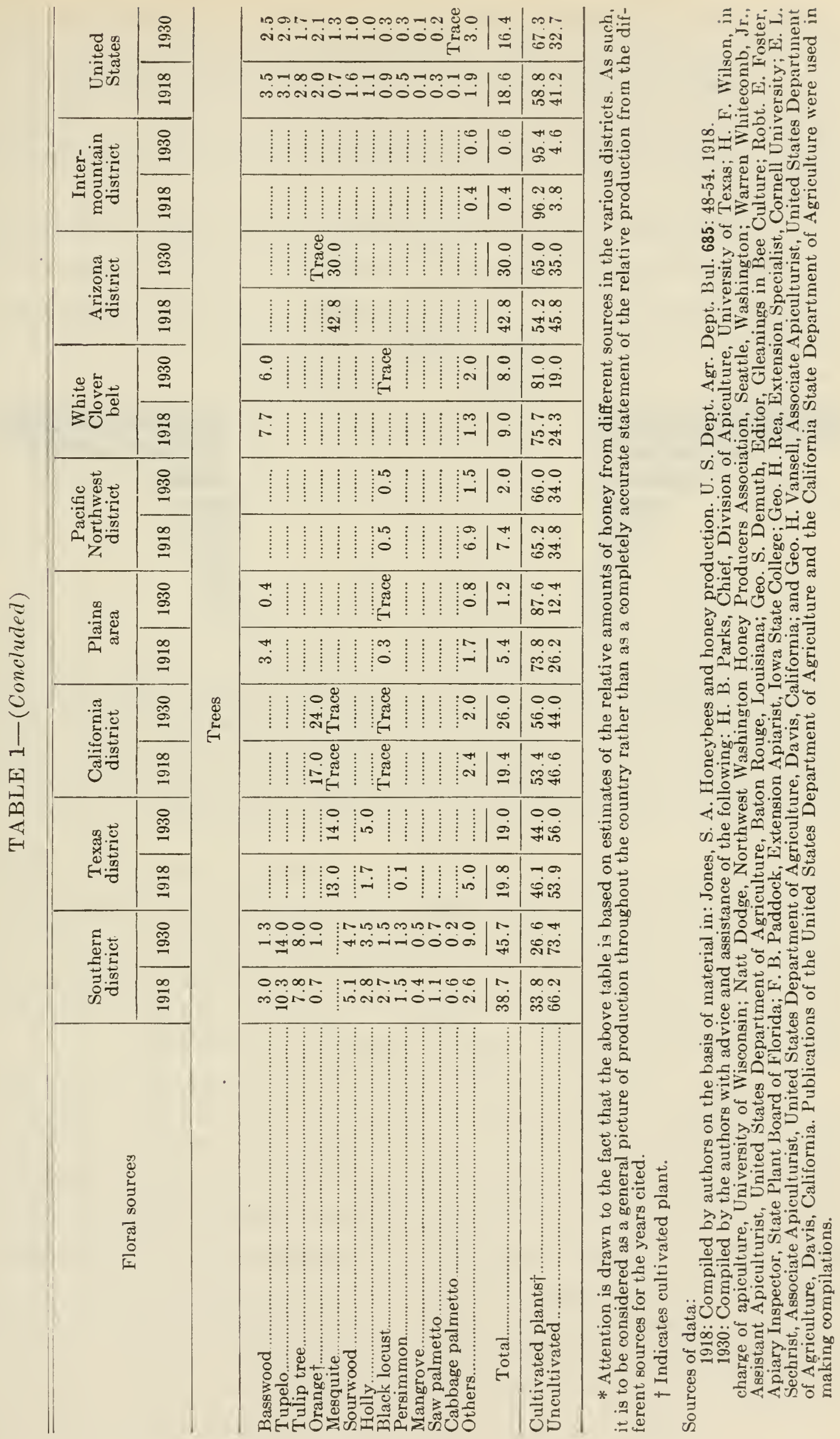


Honey Districts. - The country may be divided into eight beekeeping districts in accordance with the floral sources of the major honeys (fig. 1). While no accurate estimate is available on the total number of operators, the census data show the distribution on farms, and it is believed that the totals would not indicate a great relative variation from these.

By far the largest number of farm operators are in the southern district. The most intensive area, so far as numbers of beekeepers are con-

Honey Production and Colonies of Bees, United S'tates, Average 1928-1931.

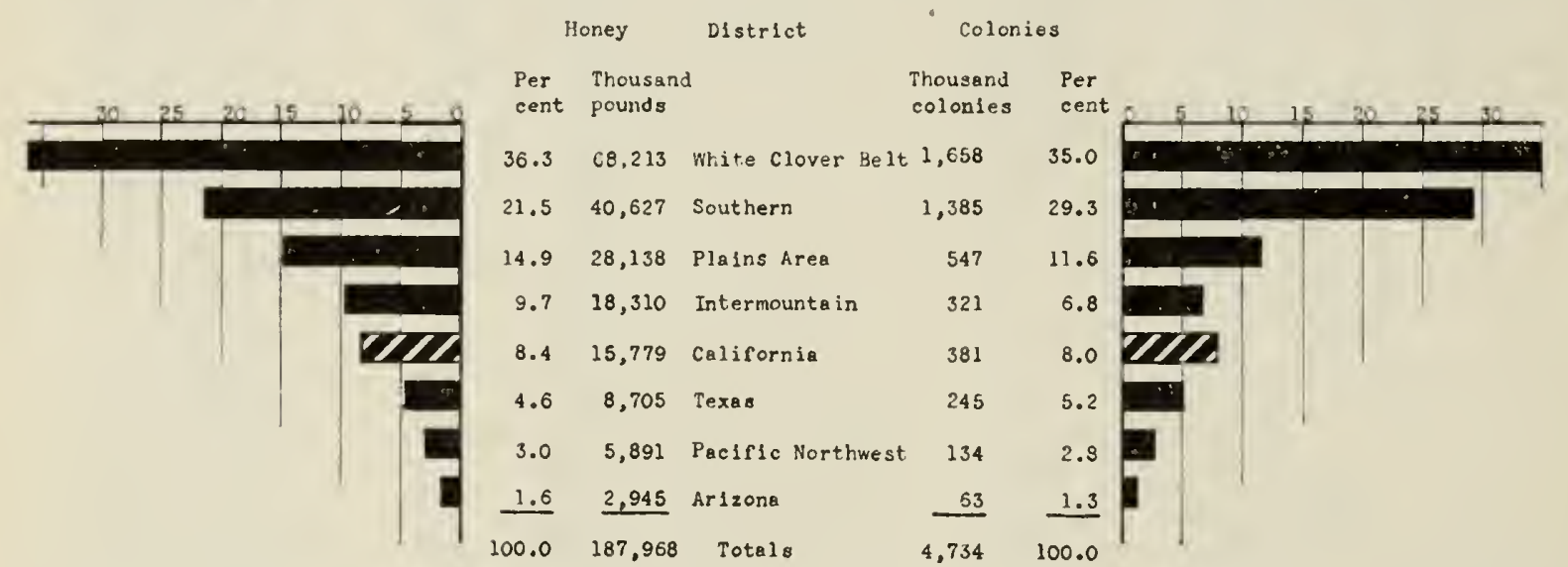

Fig. 2.-Although less than 25 per cent of the nation's honey erop is produced in the eleven western states, this area produces the largest quantity of surplus honey because of the relatively sparse population. Approximately 50 per cent of the annual crop is produced east of the Mississippi River in the area of greatest population density. Honey production generally follows colony distribution except. in the South where the production per colony is low. (Data from U. S. Dept. Agr. Rur. Agr. Econ. Honey. No. 348. 1932. Semimonthly mimeographed report.)

cerned, is in the southern Appalachians, covering portions of six states. The 1930 Census showed an average of but 5 colonies per beekeeper, and 7 pounds of honey per colony in this area. The number of operators in the California and intermountain districts is comparatively small, but they have a larger number of colonies and produce larger amounts of honey in proportion to the number engaged in the business.

In numbers of bees the White Clover Belt stands first followed closely by the southern district (fig. 2). Together with the Plains area these districts contain over 75 per cent of the bees in the United States. Inasmuch as these areas represent slightly more than one-half of the land surface of the country, it is evident that the eastern half of the United States is the most intensive bee section. In the western half of the country California has the largest number of colonies per square mile. In the ratio of colonies to crop land, Arizona and California show a greater concentration than the other western districts. 


\section{FLORAL SOURCES OF HONEY IN THE UNITED STATES}

While the supplies of nectar required for colony maintenance may come from innumerable minor floral sources, the production of an apiary usually originates from one or two major sources. The estimated contribution of the major honey plants to the United States production in 1930 is shown in table 1 . The extent of the dependence of beekeeping on agriculture is indicated by the fact that about 70 per cent of the honey crop for that year came from cultivated plants, and about 30 per cent from native and uncultivated plants. That this dependence is increasing is shown by comparison with the 1918 estimate when cultivated plants contributed about 60 per cent of the honey and native and wild sources about 40 per cent. The southern, Texas, Arizona, and California districts are much more dependent upon uncultivated flora than the other districts.

Comparatively few of the various cultivated plants-namely, clovers, alfalfa, cotton, buckwheat, and orange-are important honey sources. In 1930 the clovers (sweet, white, and alsike clovers) and alfalfa, contributed about 60 per cent of the honey production while the other cultivated plants contributed but 7 per cent. Sweet clover is the most important single honey source, having gained this position within the past decade because of its increased use in agriculture. White clover, cotton, and particularly buckwheat, show a decline, attributable to agricultural changes.

Trees, as a group, rank next to cultivated field crops contributing about 16 per cent of the total production, with the major part (14 per cent of total) being from uncultivated sources. Of the tree sources, basswood, orange, and tupelo are of nearly equal importance. They are followed by tulip tree, mesquite, sourwood, and holly. Trees are particularly important in the southern and Arizona districts.

Weeds contributed about 11 per cent of the total crop in 1930, but they have declined from about 14 per cent since 1918. Native shrubs are more important in California than in any other district, but not so much as formerly owing to the development of agriculture and to fires on ranges.

The California crop comes principally from four sources: (1) sages and wild buckwleat, 29 per cent of the state's crop; (2) alfalfa, 28 per cent; (3) orange, 24 per cent; and (4) star thistle, 5 per cent. Comparatively few changes in honey sources have taken place in the past fifteen years. There has been a small decline in sage and wild buckwheat, an increase in orange, and a new source of supply, star thistle. 


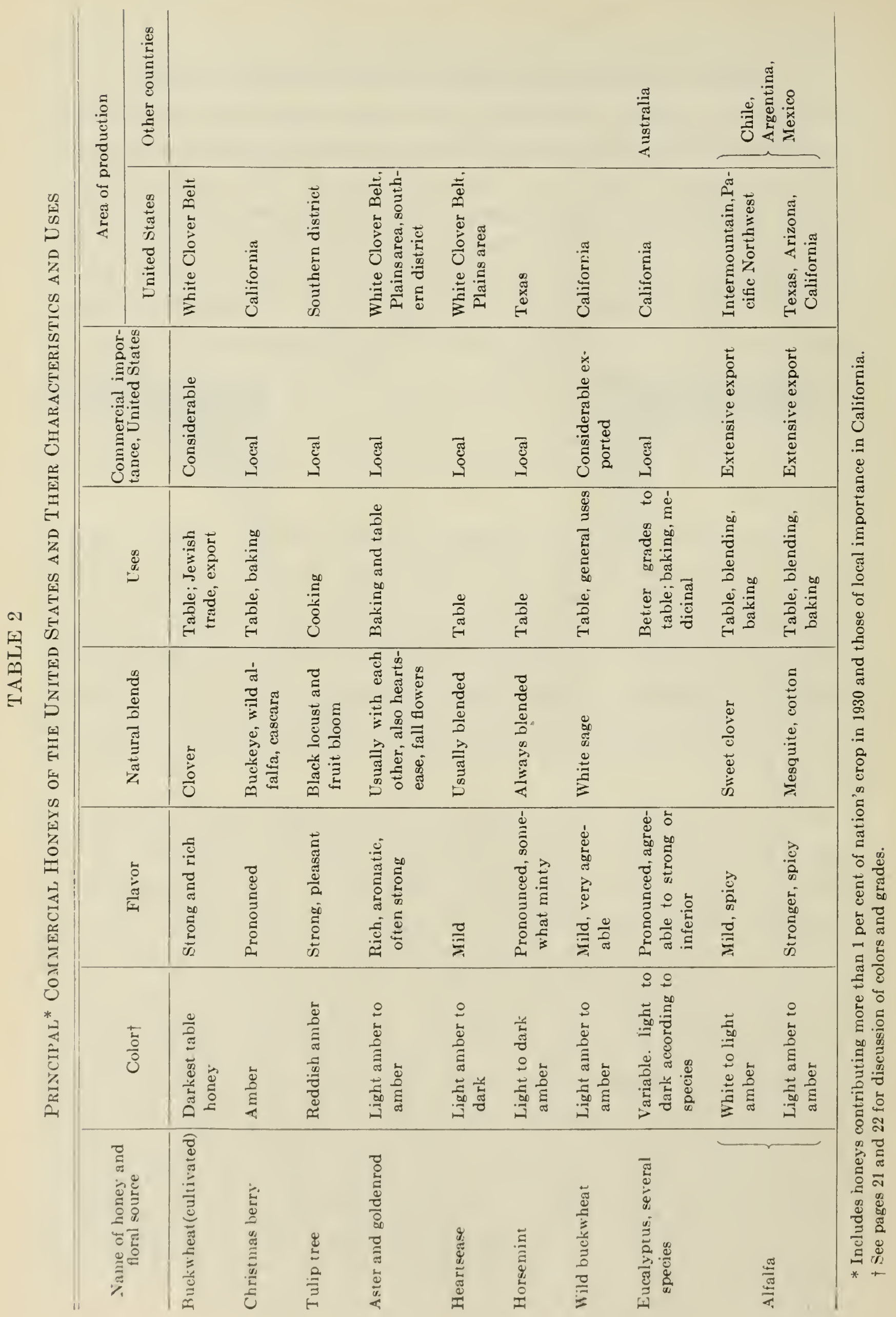




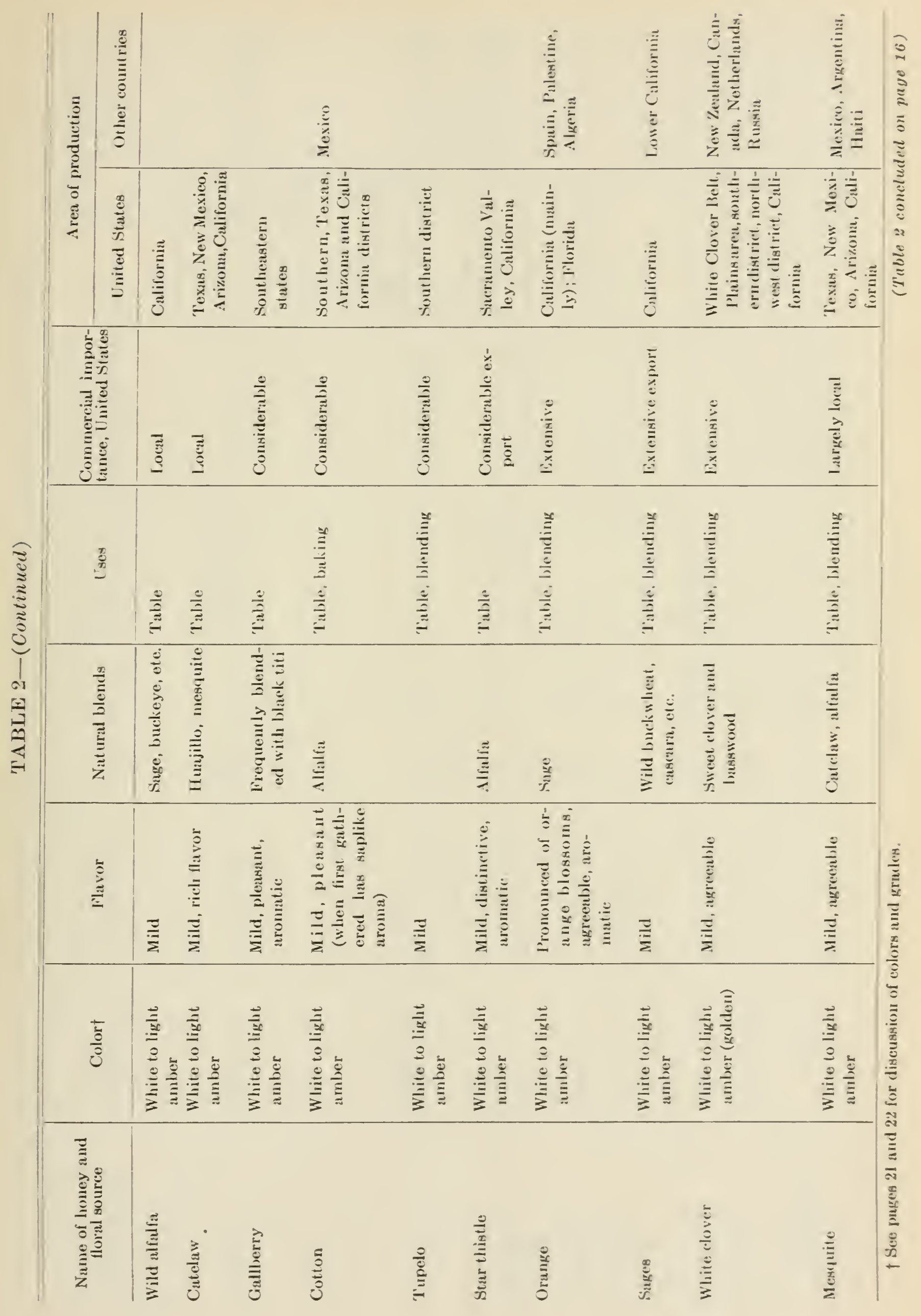




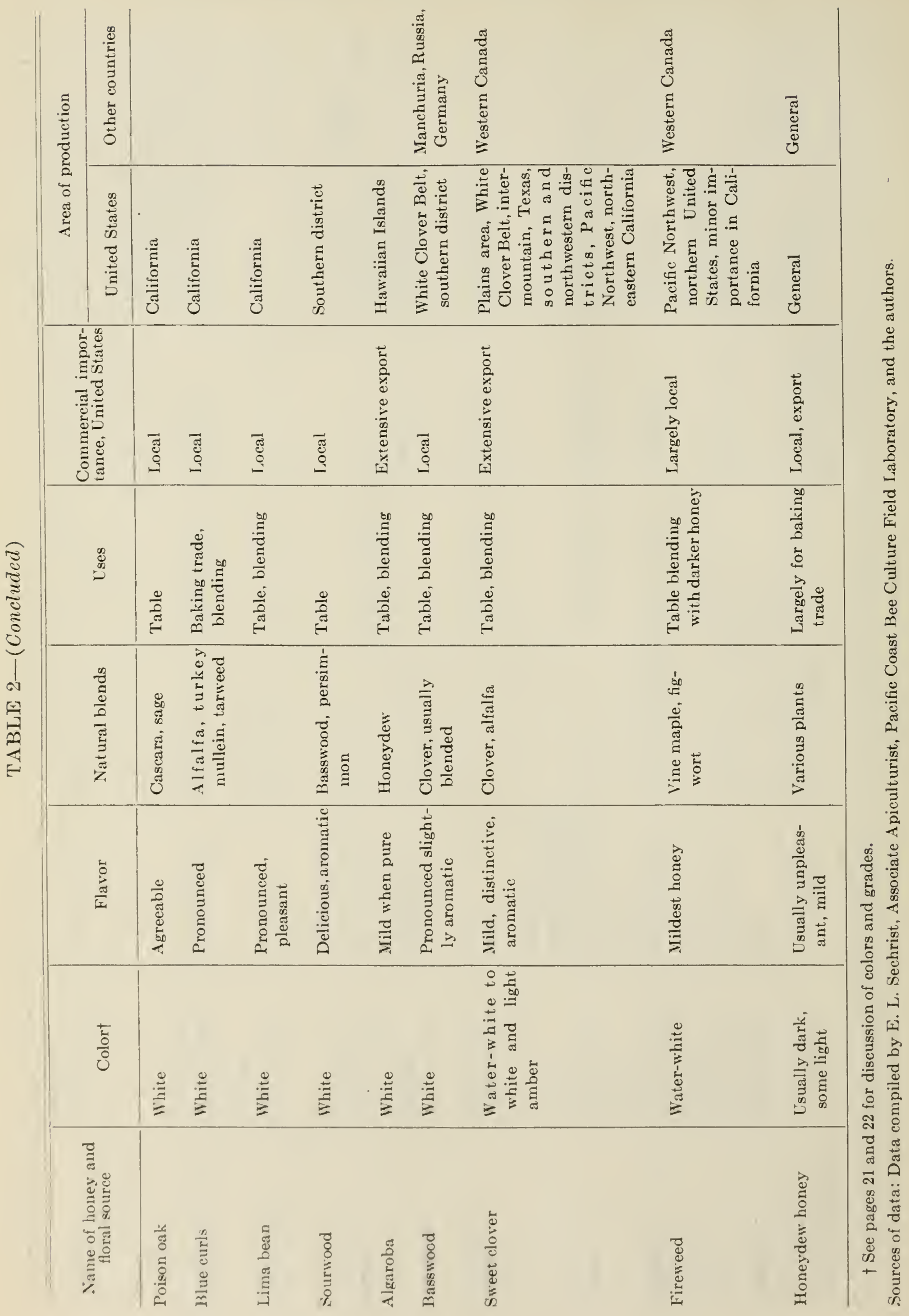


As indicated by table 1 no single honey plant is represented in all districts of the United States, and the varying product which necessarily results from the many sources is one of the problems of bee culture. The southern district evidently has the greatest diversity of honey, i.e., rather small percentages from numerous sources, while the intermountain and Arizona districts and the White Clover Belt have the most homogeneous product.

\section{PRINCIPAL TYPES OF HONEY}

Because of the great variation in honey from different plants, it is now designated in the trade according to its color and floral source. In general, the type of honey preferred in a given locality is that which is produced or has been marketed there over a considerable period. Since no one type of honey is produced in every locality, and the volume obtained from a given floral source may vary from year to year, comparisons of flavor, color, and other characteristics are of particular economic value when considering possible substitutions of one type of honey for another.

Table 2 shows a comparison of the principal honeys in the United States, arranged in order of color from dark to light. While this list contains some 26 different types of honey, only 12 are produced in sufficient volume to enter trade except locally. This table brings out clearly the variability of honey.

The majority of honeys produced in the United States are in the white and light-amber color groupings, only about 2 per cent being found in the extremes of water-white and dark. (See pages 21 and 22 for discussion of grades.) In 1917 Jones $^{11}$ estimated that the honey produced in the United States was divided as follows according to color: white, 42.8 per cent; light amber, 29.5 per cent; amber, 17.1 per cent; and dark, 10.6 per cent. It is probable that the increase in sweet-clover honey. which is white to water-white, has tended to lighten the average color of the crop, since it is blended naturally with many of the darker honeys. Furthermore, production in the southern district, where darker honeys predominate, has declined in importance, and the production of honey from cultivated buckwheat has also declined (table 1 ). In view of the higher market quotations on lighter honeys, it is also probable that effort has been made to produce more of this type.

In general, California honey is probably somewhat darker in color than the United States crop. A color classification of a representative

11 Jones, S. A. Honeybees and honey production. U. S. Dept. Agr. Dept. Bul. 685:30. 1918 . 


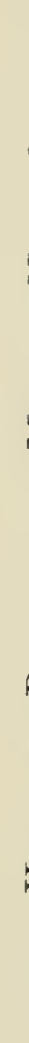

氮

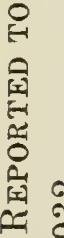

is 2

은

1/

0 ल

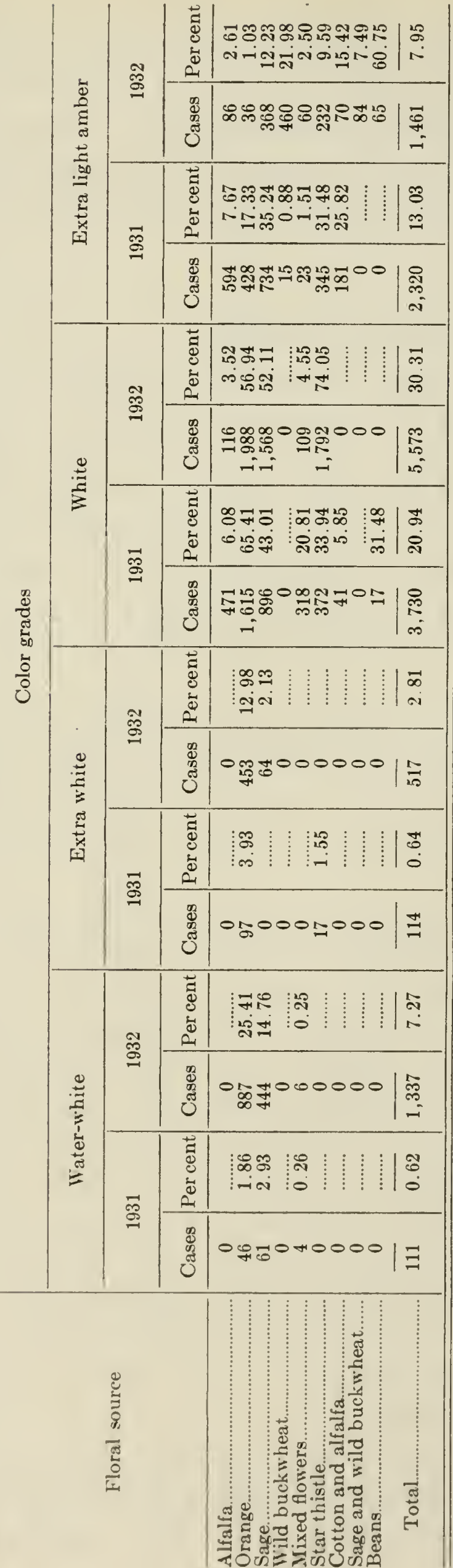

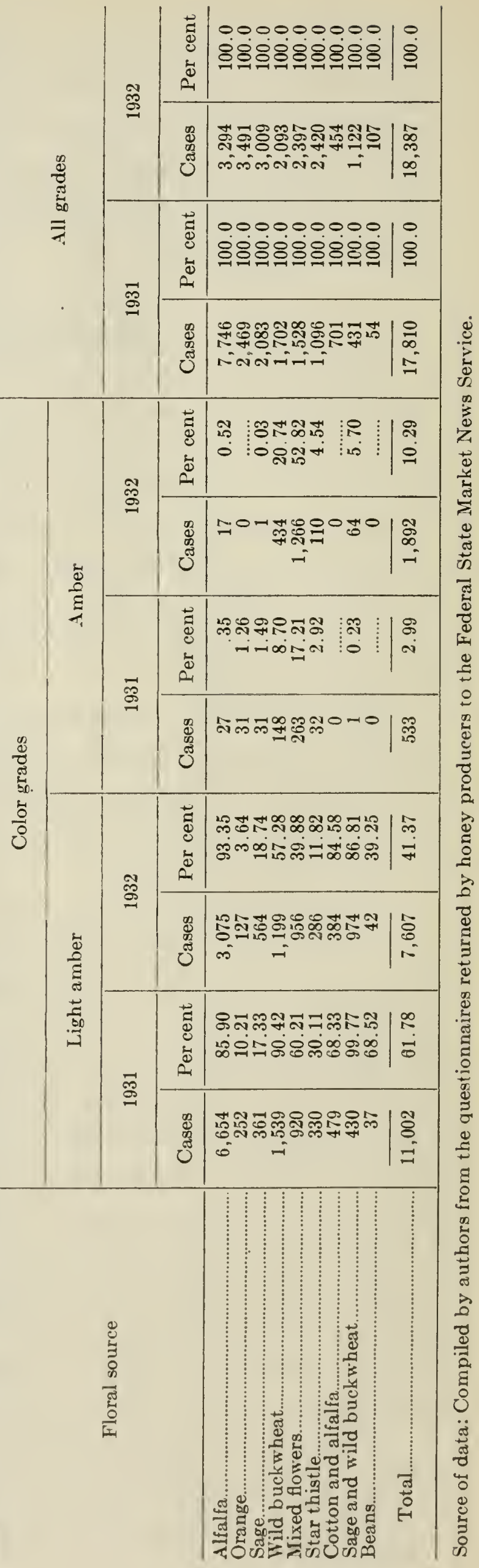


sample of the 1931 and 1932 California honey crop (table 3) indicates that it would be on the lighter side of light amber. Extremes - amber and water-white-are produced in small quantities. The limited supplies of the latter class undoubtedly have a bearing on the premiums paid for it.

Table 3 also indicates the variation in color from a given floral source. Sage honey, which was not well represented in the 1931 crop, classifies white to water-white when pure, but when blended naturally with wild buckwheat it is considerably darkened, as indicated under the sage and wild buckwheat heading in the table. Water-white orange honey is also produced in limited quantities.

\section{FORIS OF HONEY PRODUCED}

Honey is produced in the United States in four different forms: extracted, comb-section, chunk, and cut-comb. Estimates by the authors based on various sources indicate that approximately 70 per cent of the crop is extracted, the remaining 30 per cent being divided into chunk, comb-section, and cut-comb. While extracted honey is the predominating product in all districts, its relative importance varies. The bulk of combsection honey is produced in the White Clover Belt, Plains area, and the intermountain district. Cut-comb honey is produced in very small quantities in most districts. Chunk honey is produced mainly in the southern district, Texas, and the Plains area. California, Arizona, and the Pacific Northwest produce extracted honey almost to the exclusion of other forms.

The production of chunk honey requires a simple outlay of equipment, but some have questioned whether or not it lends itself to quantity production. The product, although attractive, is best suited for home consumption; it has a limited local demand, principally in the southern states and Missouri.

Comb-section honey requires a dependable, rapid honey flow from a single source, which is of sufficient duration to insure the finishing of the sections. The product should be white and not inclined to granulate readily in the comb. This limits production to certain areas. Aside from these special conditions, which are not under control of the producer, the manipulation of the colonies requires considerable skill to prevent swarming, and at the same time, to have the colonies at full strength in number and morale at the proper time. Special equipment is also necessary. Beekeepers estimate that from a production standpoint a super of comb honey ( 24 sections) averaging 18 pounds in net weight is about equal to a super of extracted honey of 40 pounds net weight. The labor requirements per unit weight are higher for comb than for extracted 
honey. Comb honey is subject to breakage in shipment and becomes ummarketable if it granulates. For this reason many dealers refuse to handle the product. However, there appears to be a distinct demand for comb honey, and it is well adapted for local sales. Marketing occurs within six months after production, usually in cases of 24 sections. When shipped, a carload contains approximately 1,300 cases.

Extracted-honey production has inherent advantages which account for its predominant position. It is adaptable to quantity production since the individual colony requires only a minimum of attention, and unskilled labor may be employed. The equipment used has more storage room available for ripening the honey, which hastens this process. Also less wax has to be secreted. These factors tend to increase the productive capacity of the colony and hence reduce the cost per pound. The nectarsource requirements are not so exacting for extracted honey, this being produced where the honey flows are light or intermittent. The color of the resulting product, whether light or dark, does not prevent it from being used in blends and a low-quality product can find uses in manufacturing processes. Furthermore, extracted honey is not injured by granulation, and since it deteriorates but slowly, it can be stored for a considerable period of time. These qualities adapt it for both interstate and export trade. 'The standard pack consists of two 5 -gallon tins to a case ( 120 pounds net). When shipped by freight, a car usually contains 265 cases. For all of the above reasons it seems likely that extracted honey will continue to be the predominant form produced.

Cut-comb honey is a recent addition to the forms offered in the market. The chief advantage over comb-section honey is that it has less exacting nectar-source requirements. There are no sections to finish off as in comb-section honey. Equipment and labor requirements are probably higher per unit than with extracted honey, and disadvantages in trade are probably similar to those for comb-section honey. The development of this product is as yet uncertain. Indications are that it will replace comb-section and chunk honey rather than extracted honey.

California is primarily an extracted-honey-producing state, but this has not always been the case. Soon after bee culture was introduced into the state (1854) the Harbison hive, designed to produce a 2-pound section of comb honey, was invented. 'This equipment was standard in the state for many years. The honey extractor was not introduced until 1871, but it appears to have made more rapid progress here than elsewhere. This may have been caused by surpluses which had to be shipped to eastern markets. Since 1910, and particularly since 1920, the trend away from comb-section honey has been rapid. 
At present California is producing less comb-section honey than it consumes. Of an estimated 19,950 cases entering California wholesale markets in 1932, only 5.0 per cent originated within the state. ${ }^{12}$ However, the estimated production is considerably higher since much of it is marketed locally. Comb honey is produced largely in the transmountain belt (fig. 3 ) from alfalfa and sweet clorer. When sage flows are copious, fine-quality comb honey can be produced, but for several years conditions have not been satisfactory and only limited quantities have been placed on the market. In the star-thistle area of the Sacramento Valley comb-honey production is slightly on the increase, but it is improbable that there will be a general trend in this direction because the California market is largely educated to extracted honer.

\section{HONEY GRADES AND GRADING}

Because of the variable nature and different forms of honey offered for sale, the potential trade importance of standardized grades can scarcely be orerestimated. At the present time, howerer. the bulk of the United States crop, both comb and extracted, is not graded to any generally recognized standards. The export trade. where United States Department of Agriculture standards are widely used. and certain states $^{13}$ which have adopted similar bases for sales on grade, are the only important exceptions to the above.

The United States Department of Agriculture standards ${ }^{14}$ cover comb-section, shallow-frame. wrapped cut-comb, chunk or bulk comb honey packed in tin, chunk or bulk comb honey packed in glass, extracted and unclassified honer; these are designed to meet the needs of all sections of the country. The standards for comb-section honey include three main grades, each of which is based upon edibility, appearance. and shipping quality.

In many respects the need for uniform grades for extracted honey has received eren less recognition than in the case of comb-section honey.

12 Computation by authors based on reports of the Federal-State Market News Service. This includes only wholesale receipts for Los Angeles and San Francisco and for the East Bay during a part of the rear. Comb horey narketed direct to retailers or consumers by producers is not included.

13 The State of Washington has recently adopted Lnited States Department of Agriculture standards and grades for honer in its "Honey Standardization Act of 1933." Oregon has empowered its department of agriculture to promulgate and enforce honey standardization regulations. Nevada has adopted the United States Department of Agriculture standards and grades for honer marketed under its Federal-State grading certificates. Wisconsin has fixed standards and a compulsory grading law, but the standards are somewhat different from the federal grades.

14 United States Department of Agriculture. United States grades, color standards. and packing requirements for honẹ. U. S. Dept. Agr. Cir. 24:29. Revised 1933. 
'The adaption of the Pfund color instrument to honcy in $1922^{15}$ enabled the setting of definite limits for each of the seven color classes (waterwhite, extra white, white, extra light amber, light amber, amber, dark), and in 1927 three United States grades for extracted honey were established irrespective of color or floral source, but based on density, cleanliness, freedom from objectionable flavor and damage of any sort.

'These developments, with the further revisions cited above, provide a fairly satisfactory basis for the grading of honey, both extracted and comb-section. Adherents to the United States grades and color standards are being gained throughout the country although, unless made compulsory by the various states, general adoption will unquestionably be slow in coming about.

\section{CALIFORNIA BEE RANGES AND THEIR UTILIZATION}

California is divided into four main honey belts (fig. 3) which are based on the floral sources of the honey produced in each. These belts are the south coast and chaparral belt, or belt I; the Sacramento-San Joaquin belt, or belt II; the transmountain belt, or belt III; and the Bay region and cut-over redwood area of the Coast Range, or belt IV. Besides the wide variation shown by honey from different floral sources, it should be noted that honey varies considerably from year to year even though from the same sources, as a result of factors beyond the control of the beekeeper. It is only possible, therefore, to lay down general rules for the honey produced in the various belts, and this further applies to the consideration of honey flows and similar discussions where, in any one year, there may be considerable deviation from what is generally considered as typical. It has not been possible to discuss in any detail the more exceptional conditions.

Belt I, South Coast and Chaparral Belt.-This belt contains some of the finest honey plants in the world-orange, sages, and wild buckwheat. 'The yield from orange fluctuates from year to year, yet it is probably one of the most dependable sources of honey. On the other hand, sages and wild buckwheat, being uncultivated, are dependent upon rainfall for growth. Rainfall is a variable factor and hence yields from these sources are inclined to be erratic.

California has a valuable honey resource in its sage ranges. Unfortunately, these have declined since 1900. Much of the more dependable range on the lower foothills has been cleared for city and agricultural purposes. However, the planting of orange trees has made up for this

15 Sechrist, 1. I. 'The color grading of honey. U. S. Dept. of Agr. Dept. Cir. $364: 7.1925$. 
Honey-Producing Belts and Distribution of Colonies in California, 1932

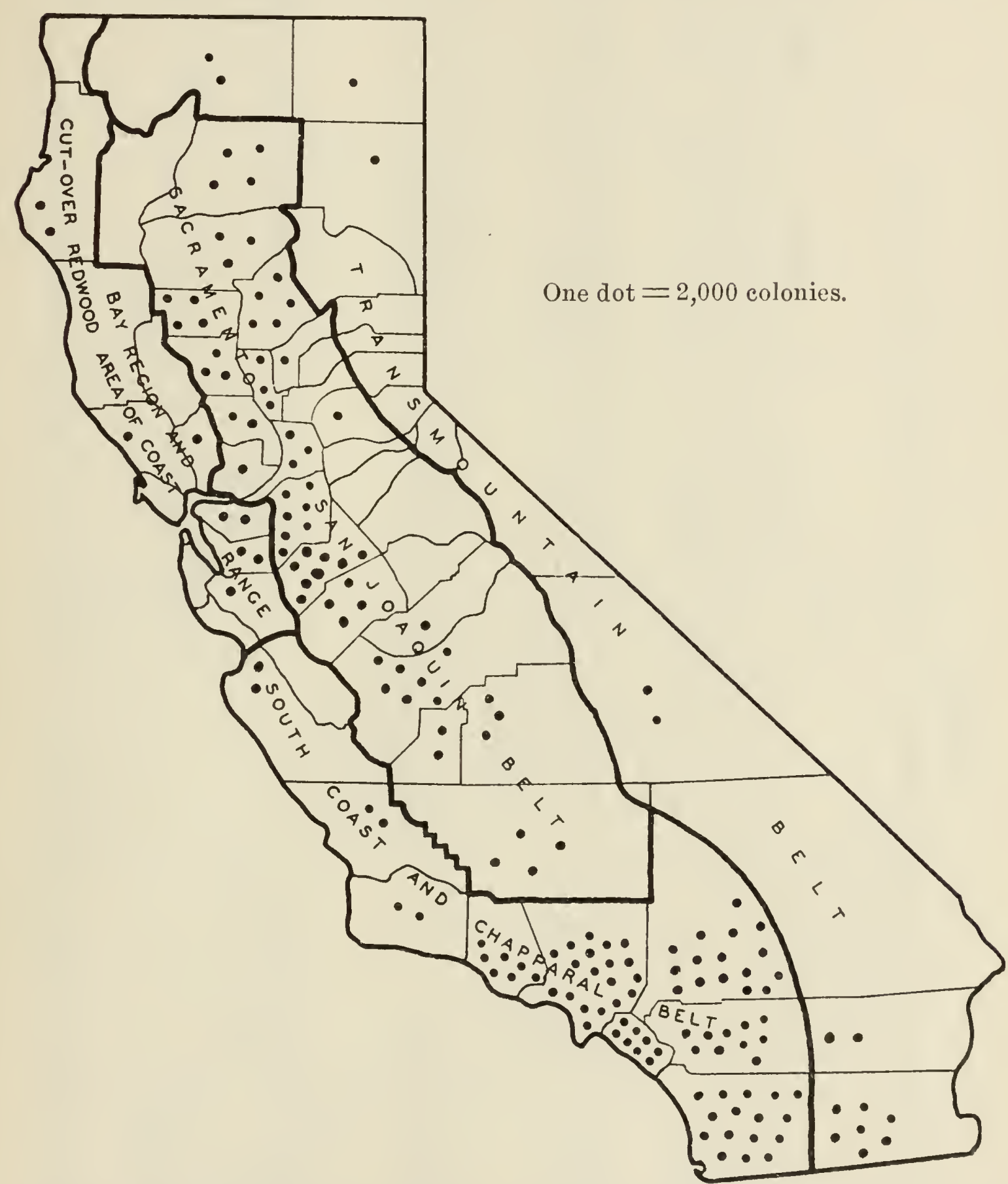

Fig. 3.-California is usually divided into four honey-producing belts, each somewhat specialized in the production of honey and bees. While the number of colonies is not closely correlated with production, it is an indication, in general, of the areas of production. The most concentrated beekeeping section is in the seven southern California counties. Outside this area and the Great Valley, numbers of colonies are relatively small. (Data compiled by authors from unpublished material obtained from California State Department of Agriculture.) 


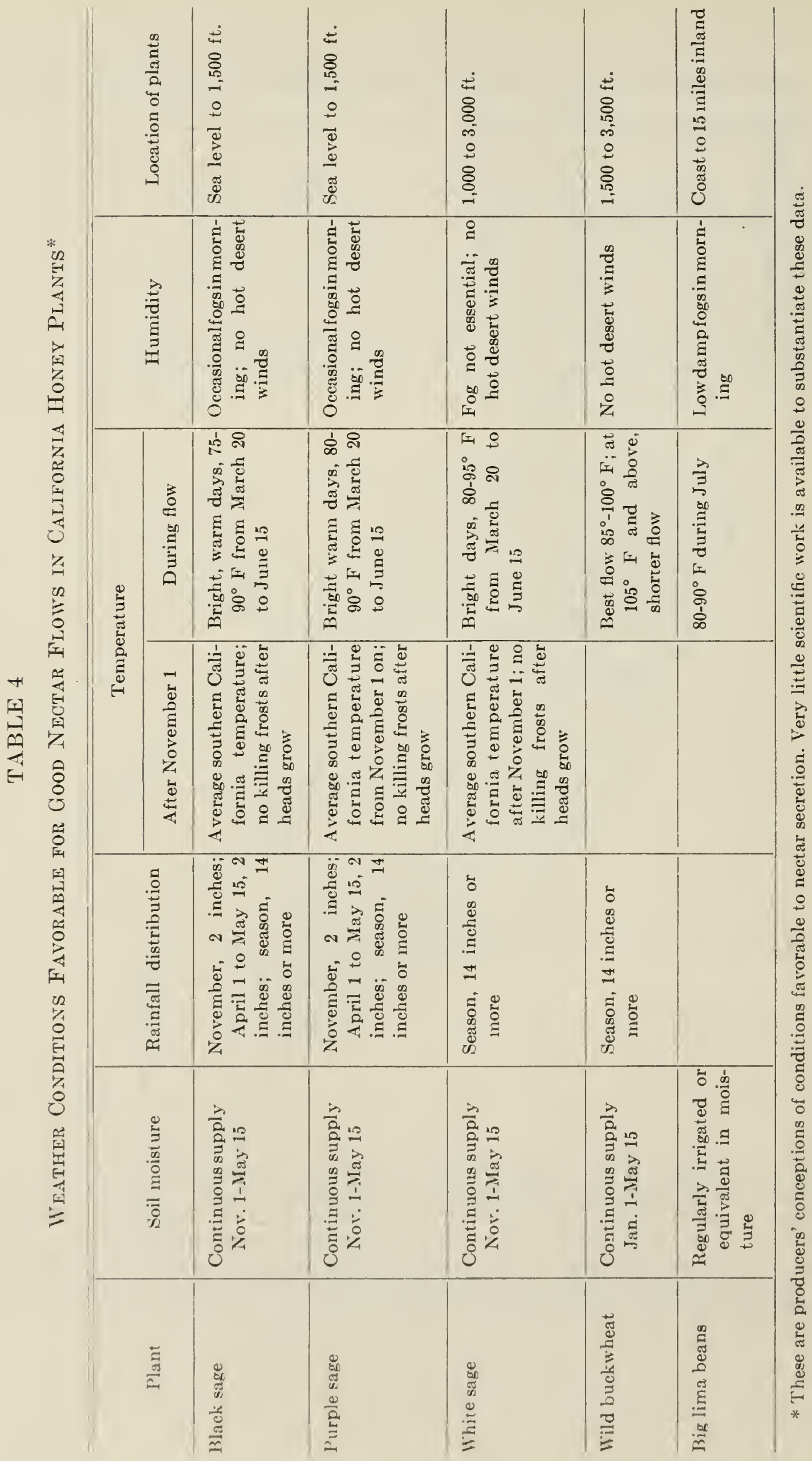




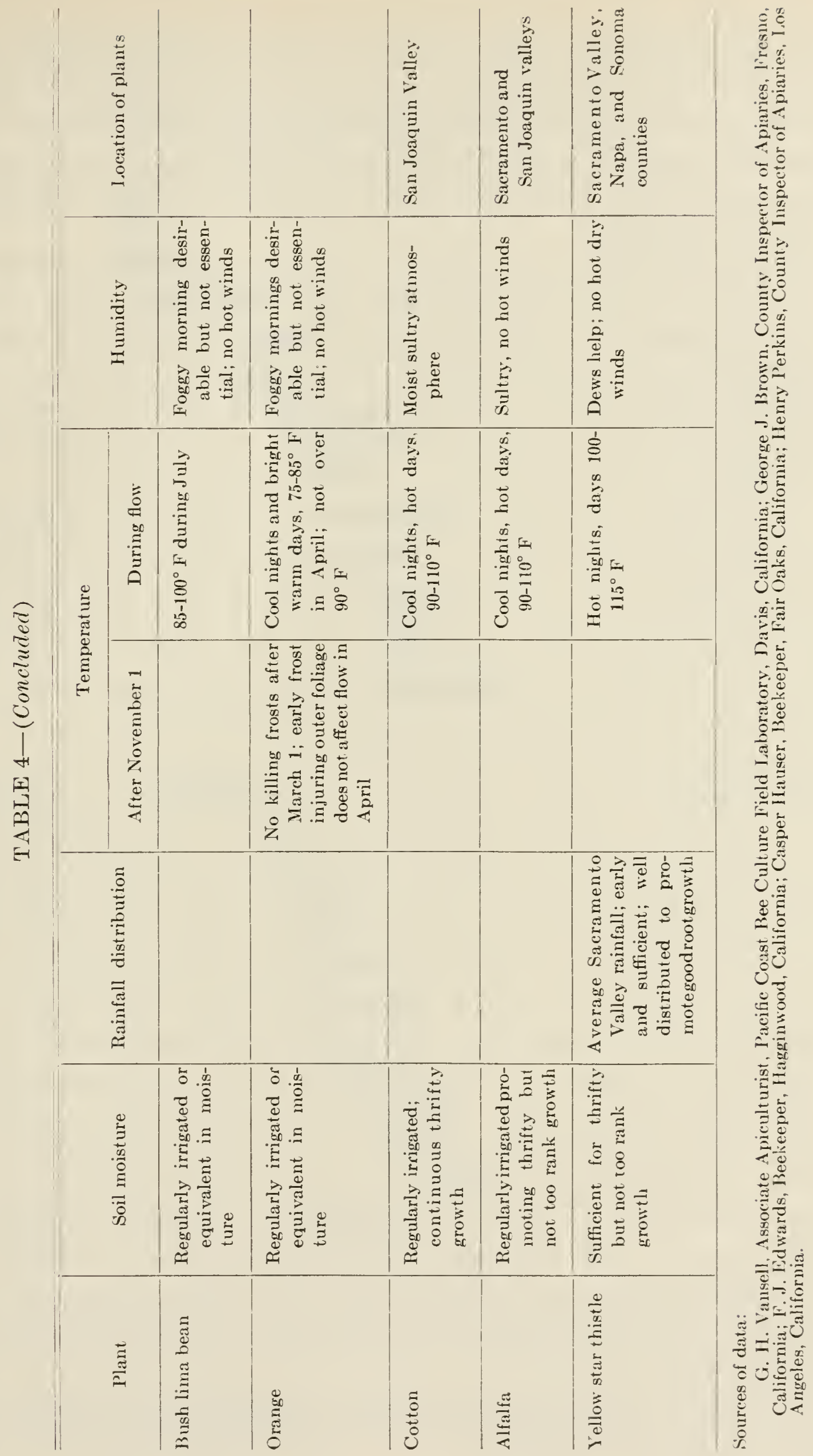


loss to a large extent. In the mountains thousands of acres of sage range have been destroyed by grazing and repeated brush fires. This loss has been particularly serious during recent dry years. In spite of the losses it seems probable that a series of years of normal or above normal rainfall would again restore sage to a place of leading importance, but the destruction of these ranges cannot go on unabated without irreparable damage to beekeeping.

Information relative to the amount of honey contributed by each of the main honey plants is very meager, and there is necessarily much variation (table 5). In 1931 and 1932 over 60 and 70 per cent respectively of the honey produced in this belt originated from sage and wild buckwheat. ${ }^{16}$ The orange evidently contributed from 25 to 33 per cent of the total produced during these two years. A characteristic of this belt is the low percentage of honey from miscellaneous sources.

For purposes of studying the succession of honey flows, belt I has been divided into three parts-I $a$, sage and wild buckwheat and orange area; $\mathrm{I} b$, sage and wild buckwheat; $\mathrm{I} c$, sage, wild buckwheat, poison oak, cascara, and toyon (figure 4). Figure 4 indicates that the orange and sages (black, white, and purple) have different honey-flow periods and ranges where they may be utilized. 'To take full advantage of these resourees, migratory beekeeping is necessary (page 38 ). The entire belt is characterized by a dearth of nectar flows from August to April, particularly during dry years. This has a profound influence on management and yields. The blooming of black sage and orange early in the spring frequently finds the bees below maximum strength for honey storage, and this is reflected in short crops. Because of the relatively early nectar flows and their short duration, the bulk of the crop is produced before July 1 . In certain years the number of colonies is considerably reduced through starvation. 'T'o overcome these difficulties beekeepers resort to migrations to other belts, or to feeding their colonies.

Sage honey is peculiar to California and stands in the first rank in quality, being white in color, mild in flavor, and practically nongranulating. Experienced producers expect one good crop, two fair crops, and two partial failures in a five-year period. During years of poor sage yields considerable honey is produced as natural blends with sage, principally sage and wild buckwheat. This honey is darker in color, may have a less delicate flavor and granulates more readily than pure sage honey. It is probably designated on the market as light-amber sage or "sage-buckwheat."

16 The increase in sage and wild-buckwheat honey in 1932 was undoubtedly a result of the heavier rainfall in the winter of 1931-32 than that which had occurred in several previous years. 
Usual Honey-Flow Periods in California : Belit [

PLANTS

Manzanita

Eucalyptus

Mustard

Orange

Black sage

White sage

Purple sage

wild buck-

wheat

Alfalfa

Lima bean

Sumac

Blue curls

Fruit bloom (almond, prune, plum )

Cascara

Black sage

Poison oak

Poison oak

Black sage

Toyon

Wild buckwheat

Wild alfalfa

Blue curls

California

buckeye

(poisonous

to bees)

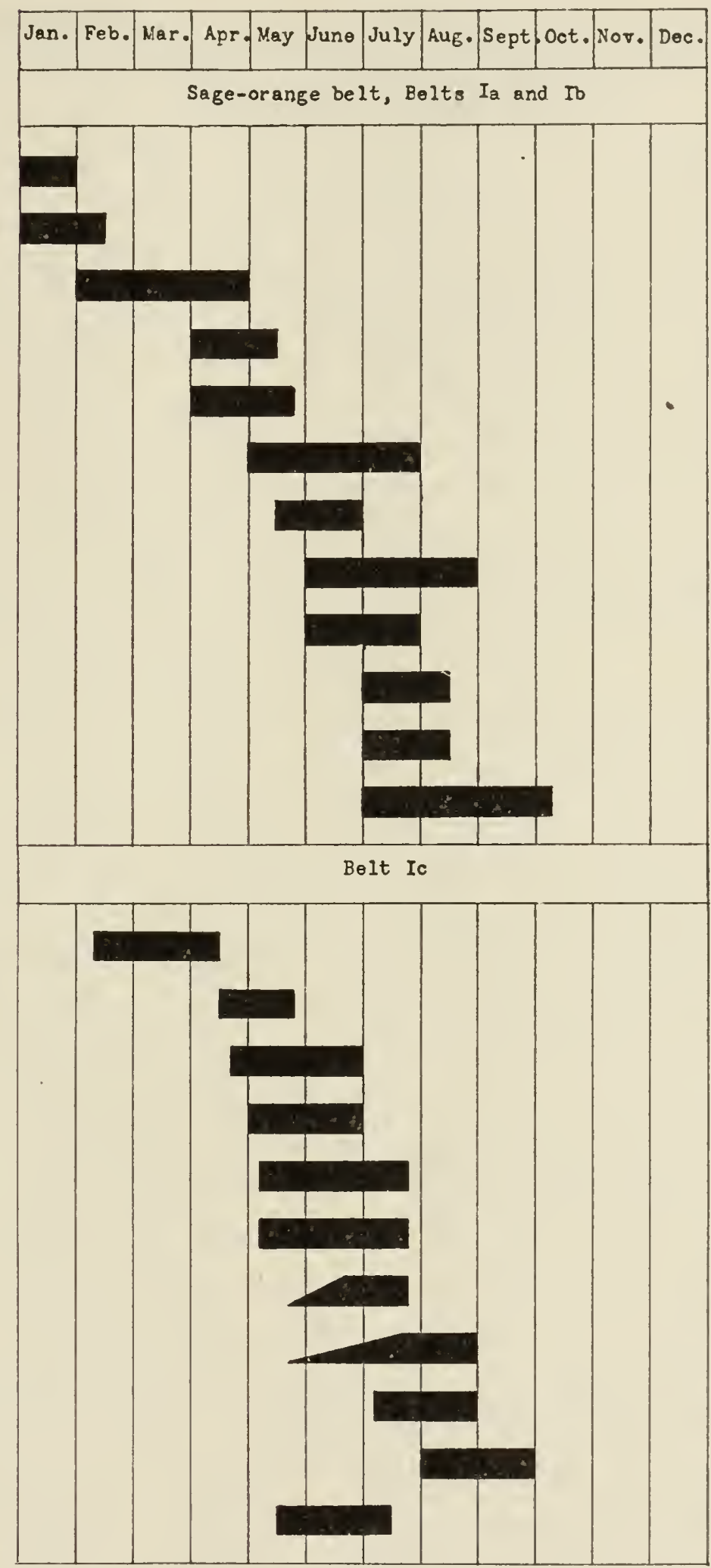

RANGE

Mountains

Cultivated areas

Cultivated areas

Orange Belt

San Diego to Santa Barbara counties

San Diego, Riverside, Los Angeles counties

Los Angeles and Ventura counties

Mountain areas

Irrigated valleys

Ventura and Los Angeles counties

Mountains

Plains

San Benito, Monterey, and San Lu is Obispo counties

Mountains

Lower levels

Lower levels

Higher levels

Higher levels

Mountains

Mountains

Mountains

Plains

Mountains

Fig. 4.- - In the sage-orange belt, belts $\mathrm{I} a$ and $\mathrm{I} b$, the principal sources of honey are sage and wild buckwheat, and orange. The orange and black-sage flows are the earliest major honey flows in the United States. Note the dearth of flows in the fall and early spring. In belt Ic sage, poison oak, cascara, and toyon are the chief sources of honey. Here also there is a dearth of flows in the fall and spring. A check list of scientific plant names is given in table 34 . The attention of the reader is called to: Vansell, G. H. Nectar and pollen plants of California. California Agr. Exp. Sta. Bul. 517:1-55. 1931. 


\section{TABLE 5}

Distribution of Extracted California Honey Entering Wholesale Markets of Los Angeles and San Francisco Bay Region According to Floral Sources, 1931-1932

\begin{tabular}{|c|c|c|c|c|}
\hline \multirow{2}{*}{ Floral source } & \multicolumn{2}{|c|}{ Thousand pounds } & \multicolumn{2}{|c|}{ Per cent } \\
\hline & 1931 & 1932 & 1931 & 1932 \\
\hline \multicolumn{5}{|c|}{ Belts $\mathrm{I} a$ and $\mathrm{I} b$} \\
\hline 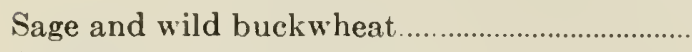 & 3,199 & 5,665 & 62.2 & 71.0 \\
\hline Orange & 1,768 & 2,087 & 34.2 & 26.2 \\
\hline Alfalfa & 91 & 21 & 1.8 & 0.3 \\
\hline Miscellaneous.. & 90 & 202 & 1.8 & 2.5 \\
\hline Total . & 5,148 & 7,975 & 10000 & 100.00 \\
\hline \multicolumn{5}{|c|}{ Belt II $a$} \\
\hline Alfalfa & 167 & 470 & 12.1 & 41.8 \\
\hline Cotton-alfalfa & 672 & 99 & 49.0 & 8.8 \\
\hline 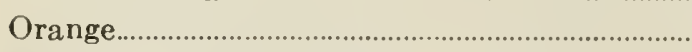 & 257 & 117 & 18.7 & 10.4 \\
\hline 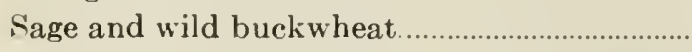 & 38 & 120 & 2.7 & 10.7 \\
\hline 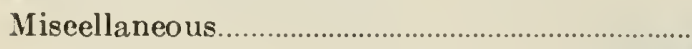 & 239 & 316 & 17.5 & 292 \\
\hline Total $\ldots \ldots \ldots \ldots \ldots \ldots \ldots \ldots \ldots \ldots \ldots \ldots \ldots \ldots \ldots \ldots$ & 1,373 & 1,122 & 100.0 & 100.0 \\
\hline \multicolumn{5}{|c|}{ Belt II $b$} \\
\hline Alfalfa $\ldots \ldots \ldots \ldots . . .$. & 560 & 285 & & 38.0 \\
\hline Star thistle............... & 135 & 418 & 16.8 & 55.9 \\
\hline Miscellaneous & 109 & 46 & 13.6 & 61 \\
\hline Total .............. & 804 & 749 & $\overline{100.0}$ & $\overline{1000}$ \\
\hline \multicolumn{5}{|c|}{ Belt III } \\
\hline Alfalfa & 1,372 & 432 & 99.1 & 86.6 \\
\hline 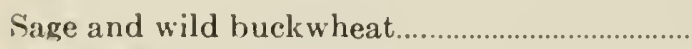 & 12 & —* & 0.9 & ......... \\
\hline Mesquite & - & 66 & ........ & 13.4 \\
\hline Total & 1,384 & 498 & 100.0 & 1000 \\
\hline \multicolumn{5}{|c|}{ Total helts $\mathrm{I} a, \mathrm{I} b, \mathrm{I} \mathrm{I} a, \mathrm{I} \mathrm{I} b$, III } \\
\hline Siage and wild buckwheat... & 3,255 & 5,785 & 37.3 & 55.9 \\
\hline Alfalfa. & 2,189 & 1,208 & 25.1 & 11.6 \\
\hline Orange & 2,025 & 2,204 & 23.2 & 21.3 \\
\hline 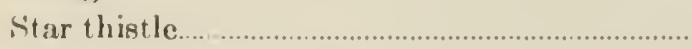 & 135 & 418 & 1.6 & 4.0 \\
\hline Cotton and alfalfa ....... & 672 & 99 & 7.7 & 1.0 \\
\hline Miscellaneous . ......... & 438 & 630 & 51 & 6.2 \\
\hline 'Total & 8,716 & 10,345 & 100.0 & 100.0 \\
\hline
\end{tabular}

* Dash indicates data not available. In this case amounts are probably small. Sinuree of data:

Compiled by authors from reports issued l,y Federal-sitate Market News service. 
Belt II, Sacramento-San Joaquin Belt.-This is the most diversified bee-culture area in the state. Not only are honey and wax produced, but also queen and package bees (pages 93 and 99); and it is the principal area where bees are rented for fruit pollination (page 103). Alfalfa, the leading honey-producing plant of the area (table 5), is a more dependable source than the native vegetation in belt $\mathrm{I}$. In spite of its being an irrigated crop, yields from alfalfa fluctuate considerably.

Trends in alfalfa production may be expected to have an influence on beekeeping. Between 1910 and 1920, the acreage devoted to this crop in California doubled, but in the next decade there was only a slight increase. ${ }^{17}$ In fact, in certain parts of the San Joaquin Valley, there has been a perceptible acreage decrease during the latter period. To be utilized by the beekeeper, alfalfa must be permitted to bloom, as in seed production and in grazing. With the increase in dairying, alfalfa has been cut at an earlier growth stage before the appearance of many blossoms. This has reduced the honey-producing possibilities of alfalfa and has unquestionably affected beekeeping.

The alfalfa weevil in the intermountain states affected beekeeping adversely during certain periods. What effect its recent introduction into California will have upon beekeeping is as yet problematical.

Some of the losses resulting from changes in alfalfa production and its utilization have been made up by the increased acreages of cotton ${ }^{18}$ over a period of years in the southern, and of Baby Lima beans in the northern, San Joaquin Valley. Other honey plants (jackass clover, spikeweed, blue curls and lippia) have been affected adversely by drought and a lowered water table, and a similar effect was noted in the adjacent sage area of the Inner Coast Range. This condition cannot be viewed as permanent because a series of years with normal rainfall will probably restore former productivity. Nevertheless, factors in the San Joaquin Valley beyond the producer's control have undoubtedly reduced his production.

In view of the differences in the secondary nectar sources, this belt can be separated into two parts-II $a$, the San Joaquin Valley; and IIb, the Sacramento Valley. The succession of nectar flows also differs somewhat (figure 5). In common, both valleys have long intermittent nectarflow periods lasting from February to November, but there is a decided tendency toward dearth during May. Since the major honey flow comes in June, July, and August, the maintenance of colony strength and morale during the period of dearth is the chief management problem.

17 Braun, E. W. Alfalfa. Califormia Agr. Exp. Sta. Bul. 521:1-37. 1931.

18 The California Crop Reporting Service estimates, however, that cotton acreages in the San Joaquin Valley have declined from 238,200 acres in 1930 to 115,700 acres in 1932. 
Usual Honey-Flaow Periods in California : Belí II

PLANTS

Fruit blooin, mustard, wild flowers

Orange

Sage

Lippia

Wild alfalfa

Alfalfa

Cotton

Bush Lima bean

Jackass clover

Spikeweed

Blue curls

California buckeye (poisonous to bees)

\section{Manzanita}

Fruit bloom

Eucalyptus

Coffee berry, poison oak

Isippia

Toyon

Buttonwillow

\section{Alfalfa}

Star thistle

Blue curls

California buckeye (poisonous to bees)

\begin{tabular}{|c|c|c|c|c|c|c|c|c|c|c|c|}
\hline Jan. & Feb. & MQS. & Apr. & May & June & July & Aug. & Sept & loct. & Nor. & $\mathrm{Dec}$ \\
\hline
\end{tabular}

\begin{tabular}{|c|l|l|l|l|l|l|l|l|l|l|}
\hline & & & & & & & & & & \\
\end{tabular}

More in north end of Valley

Tulare County

Inner Coast Range

Lower San Joaquin River

Foothills : Sierra

Nevada

General in Valley

South half of Valley

North half of Valley

Overflow land

South half of Valley

Plains

Foothills : Sierra

Nevada

Sacramento Valley, Belt IIb

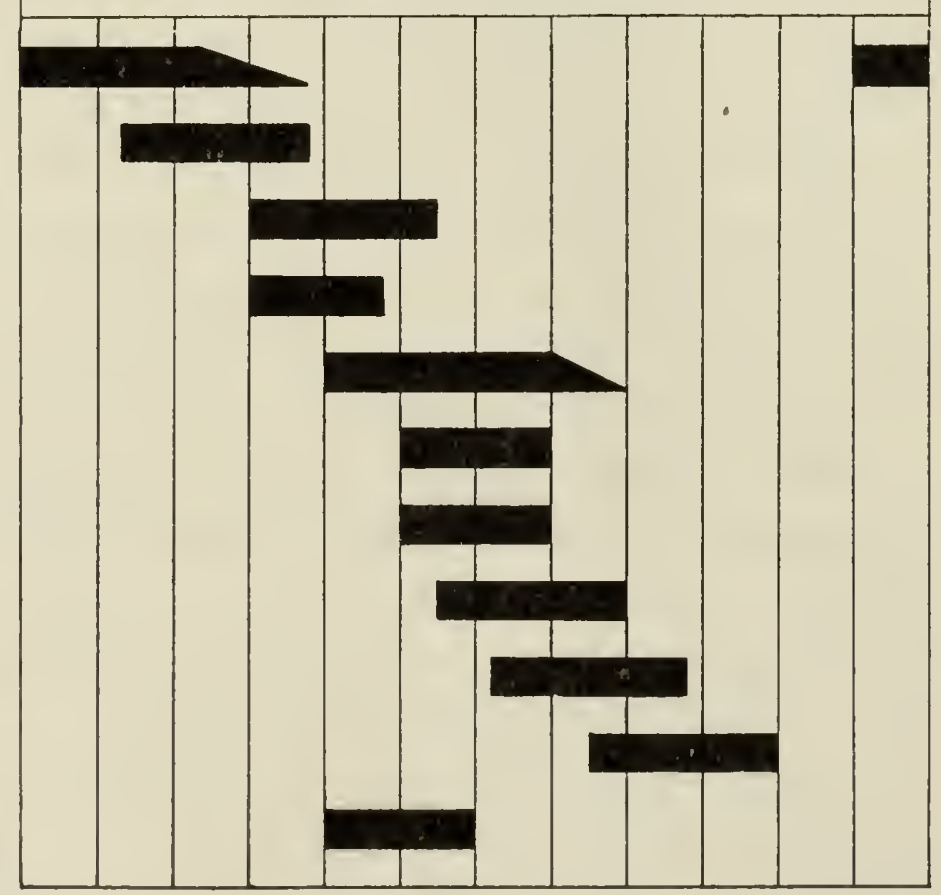

Foothills: Coast Range, Sierra Nevada

Valley

Foothills: Sierra Nevada, Coast Range

Sacramento Delta

Foothills : Coast Range, Sierra Nevada

Foothills and Valley, along streams only

Valley

Valley: pastures, grain fields, waste places

Plains

Foothills, up to $4,000 \mathrm{ft}$.

Fig. 5.-In the San Joaquin Valley, belt II $a$, the bulk of the honey is produced from alfalfa and cotton, and in this area there is a dearth of honey flows during May. The orange flow is more or less local to Tulare County. In the Sacramento Valley, belt II $\mathcal{b}$, comparatively early flows make possible the package-bee business. The main honey crop of the belt, however, is produced later in the year from star thistle and alfalfa. A check list of scientific plant names is given in table 34 . 
To attain this end, beekeepers generally endeavor to find some minor nectar source, such as red gum, Eucalyptus rostrata, mustard, or some plants in the foothills of the Sierra Nevada (page 32). They often migrate to these sources although some have had a measure of success by dequeening prior to the dearth or by selling surplus bees in packages.

In the southern end of the San Joaquin Valley about 25,000 colonies are moved into the orange section in Tulare County in the spring. Since this section is devoid of later nectar supplies, the bees are moved out again within six weeks. The fall flows from cotton and blue curls and the spring flows from wild flowers and fruit in that part of the valley are more favorable for developing colonies for the orange flow than are the honey flows found in southern California. Recent increased cotton plantings have probably resulted in a considerable natural blending with alfalfa (table 3 ), making the crop lighter in color.

In the northern end of the San Joaquin Valley where there is no orange flow, bees are rented for pollination and sold as package bees. Since there is no cotton, the honey produced is largely pure alfalfa. The bulk of the surplus honey in the San Joaquin Valley is produced before August 1.

The main beekeeping features of the Sacramento Valley are the long season of nectar flow, the large extent to which bees are rented for fruit pollination (page 103), and the fact that it is the center of package bee and queen shipping (pages 99 and 93). This Valley has the longest nectar-flow period in the state (fig. 5), making it ideal for bee production. While alfalfa is probably the main honey source (table 3 ), the utilization of star thistle since 1922 has aided considerably in the development of beekeeping. Unlike alfalfa, star thistle, an annual plant, is dependent upon rainfall and river overflows, which cause its production to be erratic. It is spreading, and it is likely to become even more important in the future. The bulk of the Sacramento Valley honey crop is produced between July 1 and September 1 .

Alfalfa honey produced in this entire belt is distinctive in that it is of a light-amber color and has a slightly stronger and spicier flavor than that produced at higher altitudes. ${ }^{19}$ Other characteristics are common to all alfalfa honey. Star-thistle honey is peculiar to California. Conditions in the Sacramento Valley appear to be well suited to its production, for it yields more copiously here than in other sections. The honey is of very fine quality, white in color, and of mild flavor. It is highly regarded on the export market. It is sometimes known as "Shasta Honey," and

\footnotetext{
19 Alfalfa honey produced at higher altitudes is white in color and has a mild flavor.
} 
I'sual, Honey-Flow Periods in California: Sierra Nevada Mountains

PLANTS

Manzanita

Fruit bloom

Poison oak

Creeping sage

Wild plum and cherry

Bear clover

Yerba Santa

Coffee berry

Deer-brush

Wild alfalfa

Toyon

Milkwort

Clarkia

Snowber'y

Soap plant

Tarweeds

Honeydew, incense cedar

Buckeye

(poisonous to bees)

Willow

Manzanita

Wild onion

Dandelion

Service berry

Wild plum and cherry

Bear clover

Red cascara

Lotus and clovers

Giant hysop)

Coyote mint

Wild buckwheats

Chinquapin

Foldenrod and asters

IIoneydew, incense cedar

$$
\begin{array}{|l|l|l|l|l|l|l|l|l|l|l|l|l|}
\hline \text { Jan. } & \text { Feb. Mar. } & \text { Apr. } & \text { May } & \text { Juno } & \text { July } & \text { Aug. Sept } & \text { Oct. } & \text { Nov. } & \text { Dec. } \\
\hline
\end{array}
$$

Sierra Nevadas and Siskiyous bolow 4,000 feet elevation

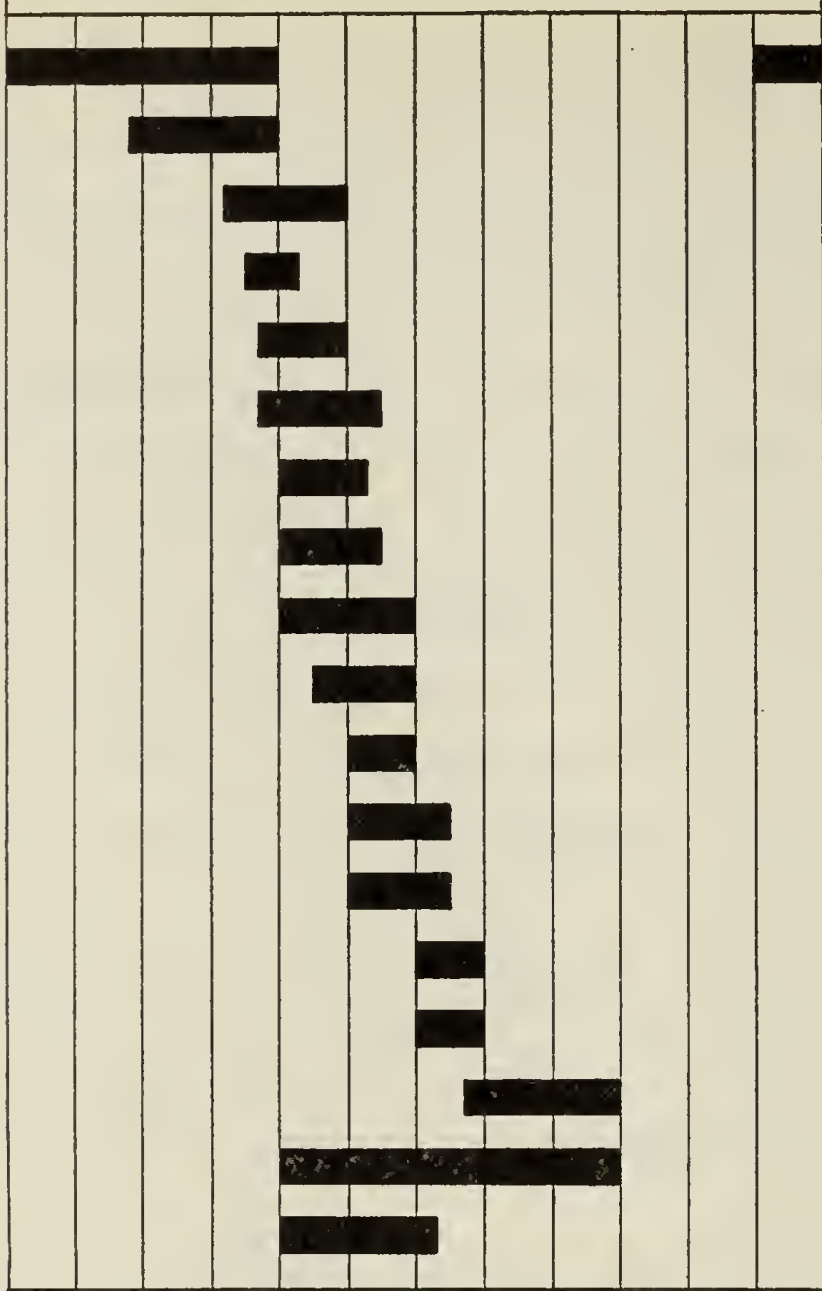

Sierra Nevadas and Sisklyous above 4,000 feet elevation

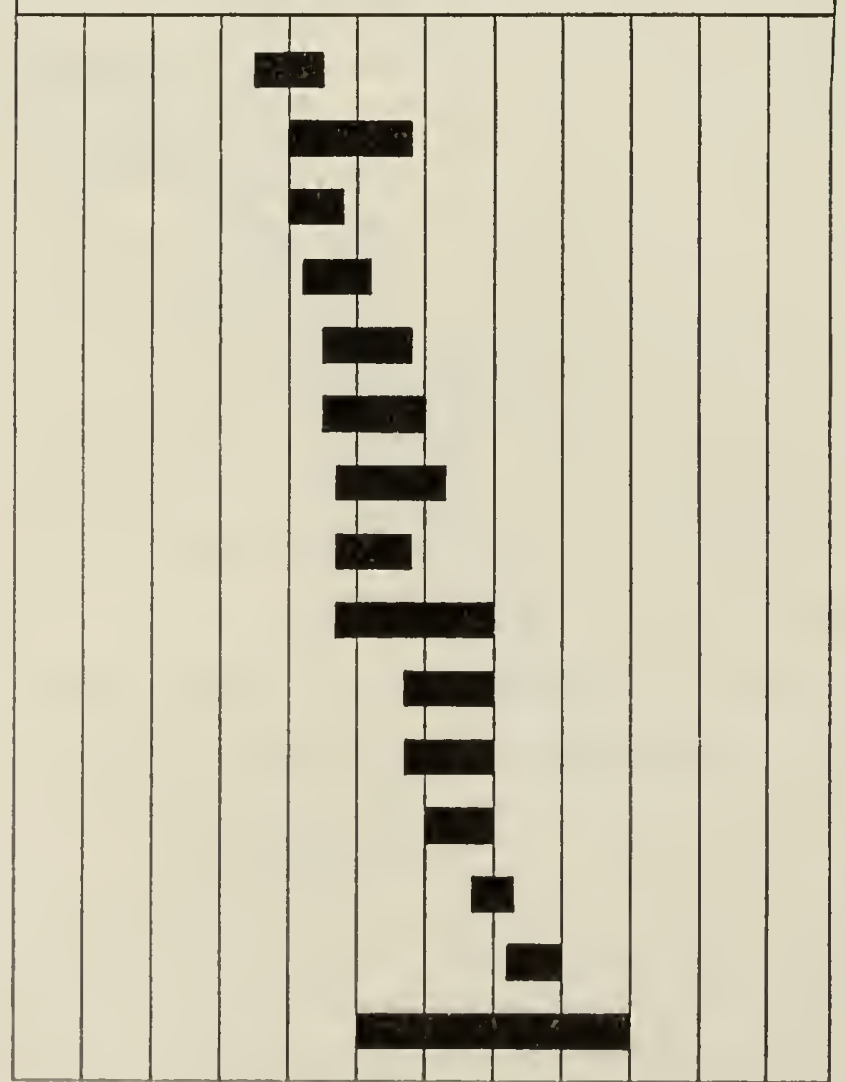

\section{RANGE}

Various species, 50 to $4,000 \mathrm{ft}$. (grows to $10,000 \mathrm{ft}$.)

Cultivated (plum, pear, apple)

50 to $4,000 \mathrm{ft}$.

1,000 to $4,000 \mathrm{ft}$., spotted-Shasta to Fresno counties

1,500 to $4,000 \mathrm{ft}$. (grows to $9,000 \mathrm{ft}$.)

3,000 to $4,000 \mathrm{ft}$. (grows to 6,000 ft.) Plumas to Kern counties

500 to $4,000 \mathrm{ft}$.

500 to $4,000 \mathrm{ft}$. (grows to 5,000 ft.)

2,000 to $4,000 \mathrm{ft}$.

10 to $2,500 \mathrm{ft}$. (Amador to Kern coun. ties)

1,000 to $3,500 \mathrm{ft}$.

1,000 to $4,000 \mathrm{ft}$.

10 to $4,000 \mathrm{ft}$. (grows to $5,000 \mathrm{ft}$.)

10 to $2,000 \mathrm{ft}$.

10 to $4,000 \mathrm{ft}$.

10 to $2,500 \mathrm{ft}$.

2,000 to $4,000 \mathrm{ft}$. (grows to 7,000 ft.)

10 to $4,000 \mathrm{ft}$.

Along streams

4,000 ft. up

Lava beds, 4,000 ft. up

$4,000 \mathrm{ft}$. up

5,000 ft.up

$4,000 \mathrm{ft}$. to top

4,000 to $6,000 \mathrm{ft}$.

Plumas to Kern counties

5,000 to $7,000 \mathrm{ft}$ Mariposa to Siskiyou c'ounties

4,000 ft. up (grows to sea level)

4,000 to $8,000 \mathrm{ft}$. (grows to $2,500 \mathrm{ft}$.)

4,000 to $6,000 \mathrm{ft}$.

$4,000 \mathrm{ft}$. up (grows to sea level)

4,000 to $8,000 \mathrm{ft}$. (grows to 3,000 it.)

4,000 to $6,600 \mathrm{ft}$ (grows to $1,000 \mathrm{ft}$.)

4,000 to $7,000 \mathrm{ft}$. (grows to $2,000 \mathrm{ft}$.)

Fig. (j.- The periods of honey flows in the bee ranges of the Sierra Nevada have in the past been relatively unknown and in consequence an attempt has been made to tabulate the honey flows below and above the 4,000-foot elevation. The flows in the higher altitudes are restricted to May, June, and July. It is felt that a greater ntilization of these bee ranges is possible. IIoneydew, included above, is produced by a seale inseet, Xylococculus macrocarpac Coleman, feeding on incense cerlar trees. $A$ cherek list of seientifie plant names is given in table 34. 
since some trade resistance has been reported to the designation of "star thistle," it might be well to promote the former term.

Probably less is known about the bee ranges of the Sierra Nevada Mountains than about those elsewhere in California. Shortage of moisture during several years previous to 1932 resulted in low yields of honey throughout the valley sections. The mountain sections, while drier than usual during these years, were always better supplied with moisture than the valleys. Beekeeping had been tried on the lower slopes, but because of buckeye most of these ventures proved to be disastrous. In recent years surfaced roads have made the upper areas of the mountains more accessible to beekeepers, and some who have gone into the mountain areas have been successful. Because of these attempts an effort has been made to gather as much information as possible on these mountain areas and to put it into usable form (figs. 6 and 7 ).

In the foothills and mountain areas below 4,000 feet (fig. 6), the buckeye is generally present. To utilize these areas one must exercise the greatest of caution to avoid buckeye poisoning. ${ }^{20}$ The blooming date of the buckeye is fairly well known, and bees should be moved before this date. There are, however, many fine honey plants in this area which will be valuable if the effect of the buckeye can be overcome or avoided.

Above 4,000 feet (fig. 6) there is a choice of two types of bee range. One is in the forested area where various honey plants are present, but the predominant source is the honeydew from a scale insect on the incense cedar. Honey from this source is heavy and dark-a typical honeydew, as it was during the seasons 1929-1932, although a product light in color has been obtained, supposedly from this source.

The other bee range above 4,000 feet is in the brush area and very little information on honey flows in this area is available. Honey plants with their approximate blooming dates observed are listed in figure 6 . The honey from this area in 1931 was white and very heavy in body. The period of honey flow was short, as would be expected. Because of the lack of information concerning this area, it is of experimental value only and commercial ventures are not recommended at the present time. Figure 7 shows the life zones of the Sierra Nevada Mountains in California with the honey plants known to be found listed in each of them. ${ }^{21}$

20 Vansell, G. H. Buckeye poisoning of the honey bee. California Agr. Exp. Sta. Cir. 301:1-12. 1926.

21 The material on life zones and honey flows was prepared with the assistance of Arthur W. Sampson, Associate Professor of Forestry and Plant Ecologist in the Experiment Station, University of California. A description of the life zones of California written by Professor Sampson will be found in: Voorhies, Edwin C., and A. B. Koughan. Economic aspects of the beef cattle industry. California Agr. Exp. Sta. Bul. 461:33-39. 1928. 
Although the figure indicates that life zones follow elevation, other conditions such as rainfall, exposure, etc., also influence the location of plants. For example, in some localities poison oak, coffee berry, toyon, milkwort, and buckeye also occur below 2,000 feet.

Lisuat, Perions of IIoney Flows of Plants at Various Elemations in the Bee Ranges of the Sierra Nevada Mountains

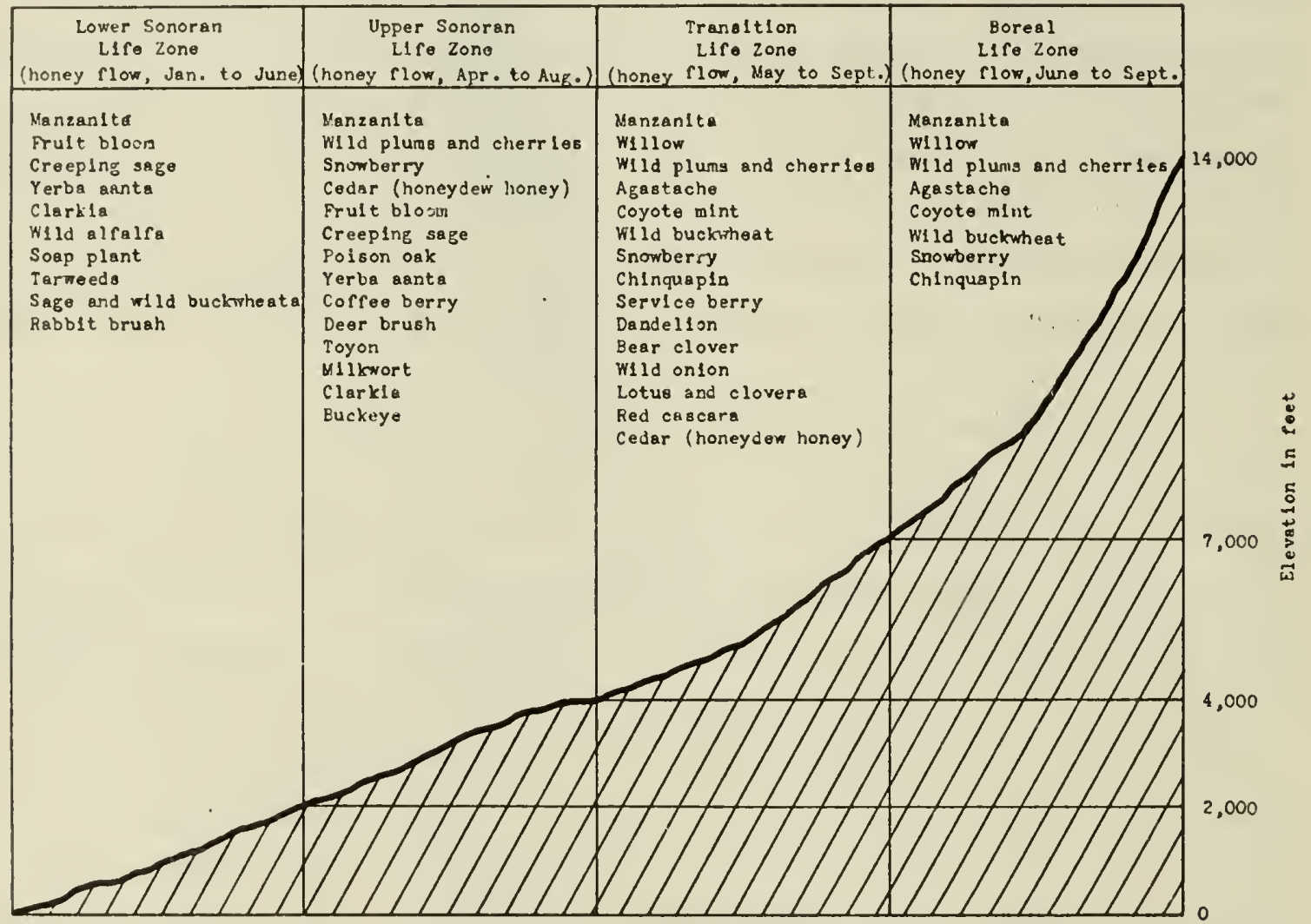

Fig. 7.-Little use has thus far been made of the bee ranges of the mountainous areas of the state. Under the proper conditions, it is believed that considerable progress in beekeeping can be made in these areas. (Data compiled by authors with the assistance of A. W. Sampson, Plant Ecologist, California Agricultural Experiment Station.) A clieck list of seientific plant names is given in table 34 .

The Lower Sonoran Zone is typically represented in the foothills area south of the Kings River in Fresno, 'Tulare, and Kern counties, but not in the other sections under consideration in the discussion of the bee ranges of the Sierra Nevada Mountains.

The following rules have been suggested concerning the blossoming dates for honey plants in the bee ranges of the Sierra Nevada:22 (1) for each 1,000-foot increase in elevation the beginning of growth and possibly blossoming ${ }^{23}$ is delayed 7 to 10 days; (2) plants growing on north and east exposures begin growth and mature seed (probably blossom)

22 The authors are indebted to Arthur. W. Sampson, Associate Professor of Forestry and Plant Ecologist, in the Experiment Station, University of California, for his criticism and advice concerning the bee ranges of the Sicra Nevada.

23 'This applies to the general blossoming period; a few species blossom very late and are distinctly different from the flora as a whole. 
about 7 days later than the same plants on the south and west exposures; (3) other conditions being the same, plants at the northern end of the state blossom from 7 to 10 days later than those in the southern end.

Belt III, Transmountain Belt.-Practically the entire crop of this area is alfalfa honey. The quality of the product varies considerably with the production area; that from Imperial and Riverside counties being light amber to amber in color, and slightly stronger in flavor than honey from Inyo, Lassen, Modoc, and Siskiyou counties. Alfalfa honey from the latter counties is among the lightest-colored produced in the state, grading from white to water-white. The bulk of California comb honey comes from these counties.

The usual periods of the honey flows in the transmountain belt are shown in figure 8 . The Imperial, Coachella, Bard, and Palo Verde valleys are separated from the rest of the area in order to facilitate the presentation of honey-flow successions. Alfalfa honey flows in these valleys are very dependable, and conditions in the spring and fall are favorable to the preparation of colonies for the alfalfa flow; this may account in part for the dependable yields. The dearth of flows comes during the hottest portion of the year (July 15 to September 1) after the surplus crop is produced. Since 1920 the alfalfa acreage has increased while that of cotton has decreased in the Imperial Valley. In spite of this, beekeeping has remained fairly stationary.

In the northern part of belt III, the winter season lasts from October to May, and therefore becomes the important management problem. It is customary to permit the bees to "fill up" the hive for winter stores with rabbit-brush honey, after the alfalfa and sweet-clover surplus has been removed. This honey is of questionable value as winter feed unless the bees have frequent flying spells for elimination purposes. In much of the area, snow and cold weather prevent such flights, and winter losses from dysentery are frequently heavy. Winter packing might be of advantage in this area but it is not generally practiced. This is typically a nonmigratory area.

Agricultural changes in the once important heekeeping territory, Owens Valley, have reduced beekeeping almost to the vanishing point. On the other hand, good roads, increased agriculture, and improved transportation facilities have aided beekeeping in the more northern counties. Future development in beekeeping will probably follow closely that of agriculture.

Belt IV, Bay Region and Cut-over Redwood Area.-Bee culture in this area is conducted mainly for the pollination of deciduous fruit orchards, although the area contains a few commercial honey producers. 


\section{Usual Honey-Flow Periods in California: Belts III and IV}

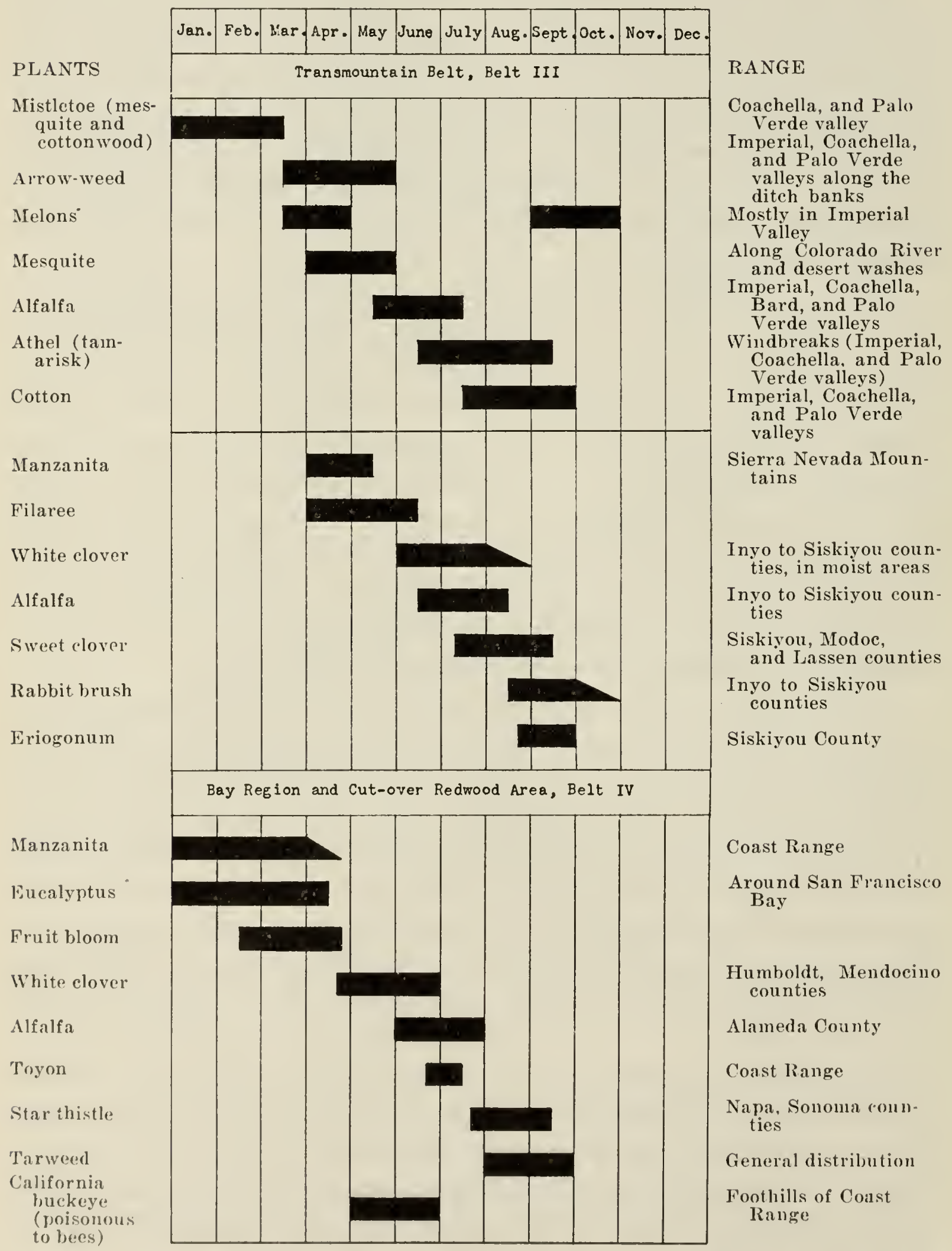

Fig. 8. - The transmountain belt, belt III, is divided into two more or less senarate parts. The southern part of belt III has the earliest flows. In the Bay region and cut-over redwood area, belt IV, eommercial honey production has made littlo progress. Beekeeping is eondueted largely for the purpose of pollinating deciduous fruit orchards. A check list of scientifie plant names is given in table 34 . 
Despite the usual recommendation of 1 colony per acre for pollination purposes, the area contains about 12,000 colonies and has about 82,000 acres of fruit trees to which bees might be of value.

In the San Francisco Bay area one species of eucalyptus, blue gum, Eucalyptus globulus, is an important early-season source of honey (fig. 8). Probably most of this type of honey reaching the market comes from this area. Eucalyptus in this area seems to secrete nectar more abundantly in alternate years. After the flow from this source it is customary to move the bees to alfalfa in the San Joaquin Valley. North of San Francisco Bay there are a few areas in which star thistle is of value. Further north in Humboldt and Del Norte counties there is some white clover and native vegetation of importance to beekeepers.

Although commercial honey production has made little progress, there is perhaps opportunity for commercial development in package-bee production. North and south of San Francisco Bay conditions are favorable for building up colonies in the spring. Since the valleys are narrow and the surrounding hills contain considerable buckeye, which is poisonous to bees, the colonies become partly reduced by midsummer. With proper management this would not necessarily prevent package-bee production, since the markets come before the buckeye blossoms.

\section{DISTRIBUTION OF BEEKEEPING IN CALIFORNIA}

Beekeepers in California have been required to register their names, number of colonies, and location with the County Agricultural Commissioner on or before March 1 of each year. While a complete registration has never been obtained, it is sufficiently representative to show the relative size and location of the industry (table 6 ). The total number of beekeepers approximated 12,000 in 1932. Slightly over 30 per cent of the operators are in the south coast and chaparral belt, while about 50 per cent are in the Sacramento-San Joaquin belt. About 4.5 per cent registered from the transmountain belt, while slightly over 10 per cent were found in the Bay region and cut-over redwood area. The latter section is relatively unimportant in numbers of operators as compared with other parts of the state, and yet this area contains large plantings of deciduous fruit trees.

The distribution of colonies gives a somewhat different picture from that of beekeepers. Slightly under one-half of the colonies reported were in the south coast and chaparral belt (belt I), while about two-fifths were reported for the Sacramento-San Joaquin belt (belt II). The relative positions in numbers of colonies occupied by the transmountain (belt III) and Bay region and cut-over redwood (belt IV) belts in this respect 
are the reverse of those with reference to numbers of beekeepers. 'The transmountain belt contained approximately double the number of colonies enumerated in the Bay region and cut-over redwood belt. Southern California counties rank high in the total number of colonies (fig. 9). Twenty-nine of the state's 58 counties contain over 90 per cent of the total colonies.

TABLE 6

Distribution of Beekeepers and Colontes in the Various IIoney Beítis in California, 1932

\begin{tabular}{|c|c|c|c|c|c|c|c|}
\hline \multirow[b]{2}{*}{ Belts } & \multirow{2}{*}{\multicolumn{2}{|c|}{ Beekeepers }} & \multirow[b]{2}{*}{ Colonies } & \multicolumn{4}{|c|}{ Per cent } \\
\hline & & & & \multicolumn{2}{|c|}{ Beekeepers } & \multicolumn{2}{|c|}{ Colonies } \\
\hline I, South coast and chaparral & & 3,650 & 169,775 & & 31.8 & & 49.2 \\
\hline $\begin{array}{r}\text { II, Sacramento-San Joaquin } \\
\text { II } a \text {, San Joaquin Valley... } \\
\text { II } b \text {, Sacramento Valley... }\end{array}$ & $\begin{array}{l}3,515 \\
2,352\end{array}$ & & $\begin{array}{l}79,062 \\
57,526\end{array}$ & $\begin{array}{l}30.6 \\
20.5\end{array}$ & & $\begin{array}{l}22.9 \\
16.7\end{array}$ & \\
\hline & & 5,867 & $-136,588$ & - & 51.1 & - & 396 \\
\hline III, Transmountain & & 528 & 26,000 & & 46 & & 7.5 \\
\hline $\begin{array}{l}\text { IV, Bay region and cut-over } \\
\text { redwood area }\end{array}$ & & 1,446 & 12,601 & & 12.6 & & 3.7 \\
\hline Total & & 11,491 & 344,964 & & 100.0 & & 100.0 \\
\hline
\end{tabular}

Sources of data:

Compilations by H. M. Krebs, Supervisor, Apiary Inspection, California State Dept. Agr., and Frank E. Todd. Associate A piculturist, Pacific States Ree Culture Field Laboratory of the United States Department of Agriculture Bureau of Entomology.

\section{MIGRATORY BEEKEEPING}

Although California is endowed with an almost continuous nectar flow throughout the year, the flow in any given locality is seasonal in nature. This, coupled with the limited flight range of the honeybee, has necessitated the moving of apiaries to take full advantage of nectar resources, particularly in years of comparative drought. Migratory beekceping requires an intimate knowledge of several localities as to nectar resourees, climate, and up-to-date information on conditions existing in a given season. Cheap transportation, accessible locations, and equipment which will stand up under repeated rough handling are essentials. Obviously it is confined largely to specialists in bee culture.

The chicf advantages of migratory beckeeping are the opportunity afforded for the selection of choice locations, utilization of equipment over longer periods of the year, and increased per-colony production. Many ventures have been unsuceessful because of inexperience, lack of knowledge of eonditions, and heavy cost factors. 'There is danger of loss 
in transit from smothering of colonies, and transportation costs are considerable, while expected honey flows fail to materialize. The value of a

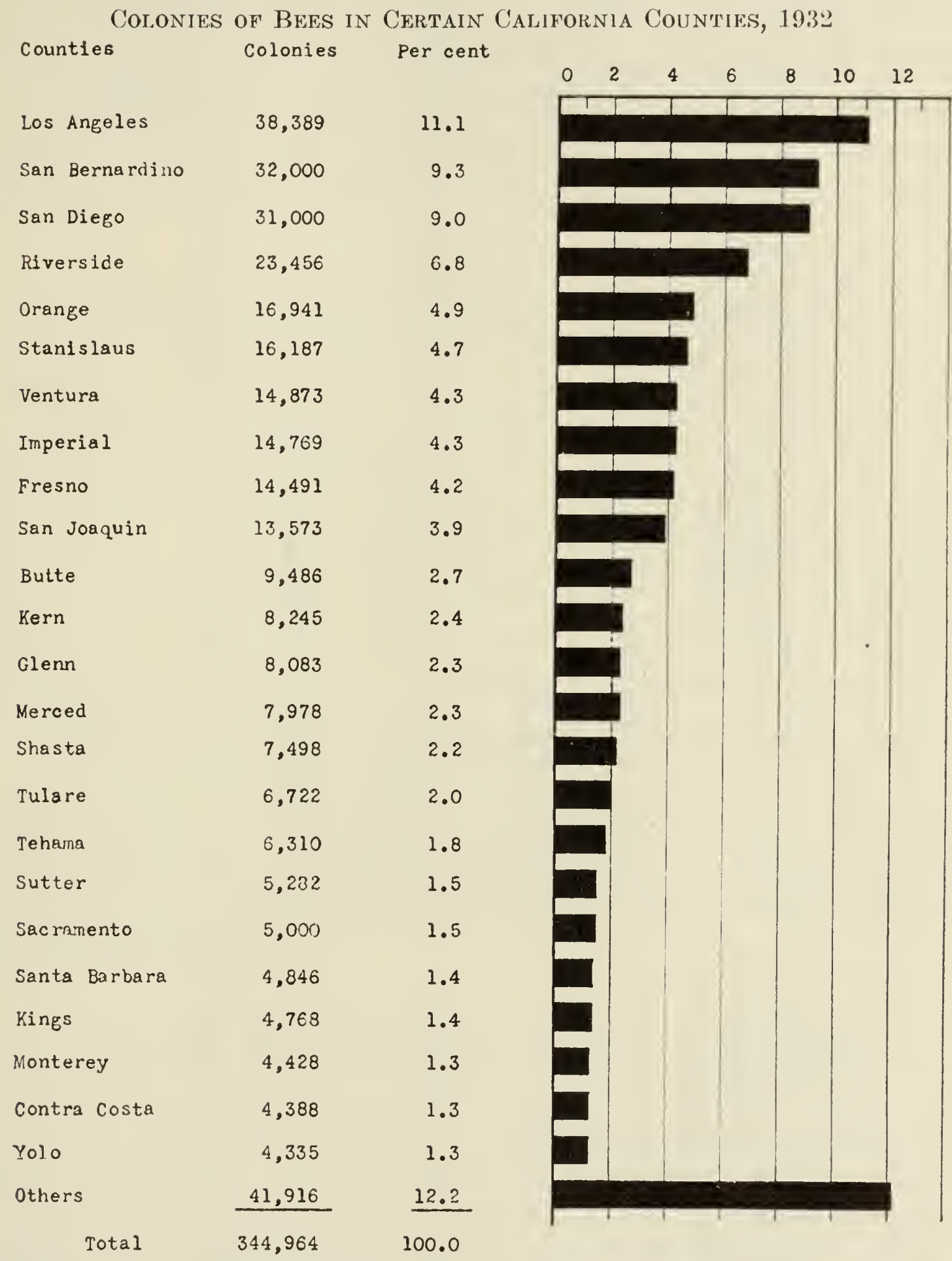

Fig. 9.-Seven of California's fifty-eight counties contain over 50 per cent of the state's bee population. The five leading counties in numbers of colonies are in southern California. (Data compiled by authors from unpublished material received from California State Department of Agriculture.)

honey crop from a moved apiary should be greater than from a nonmigratory one because of the additional costs involved. The use of combless screen cages and package bees may offer cost-reduction opportunities in migratory beekeeping not as yet fully exploited. 


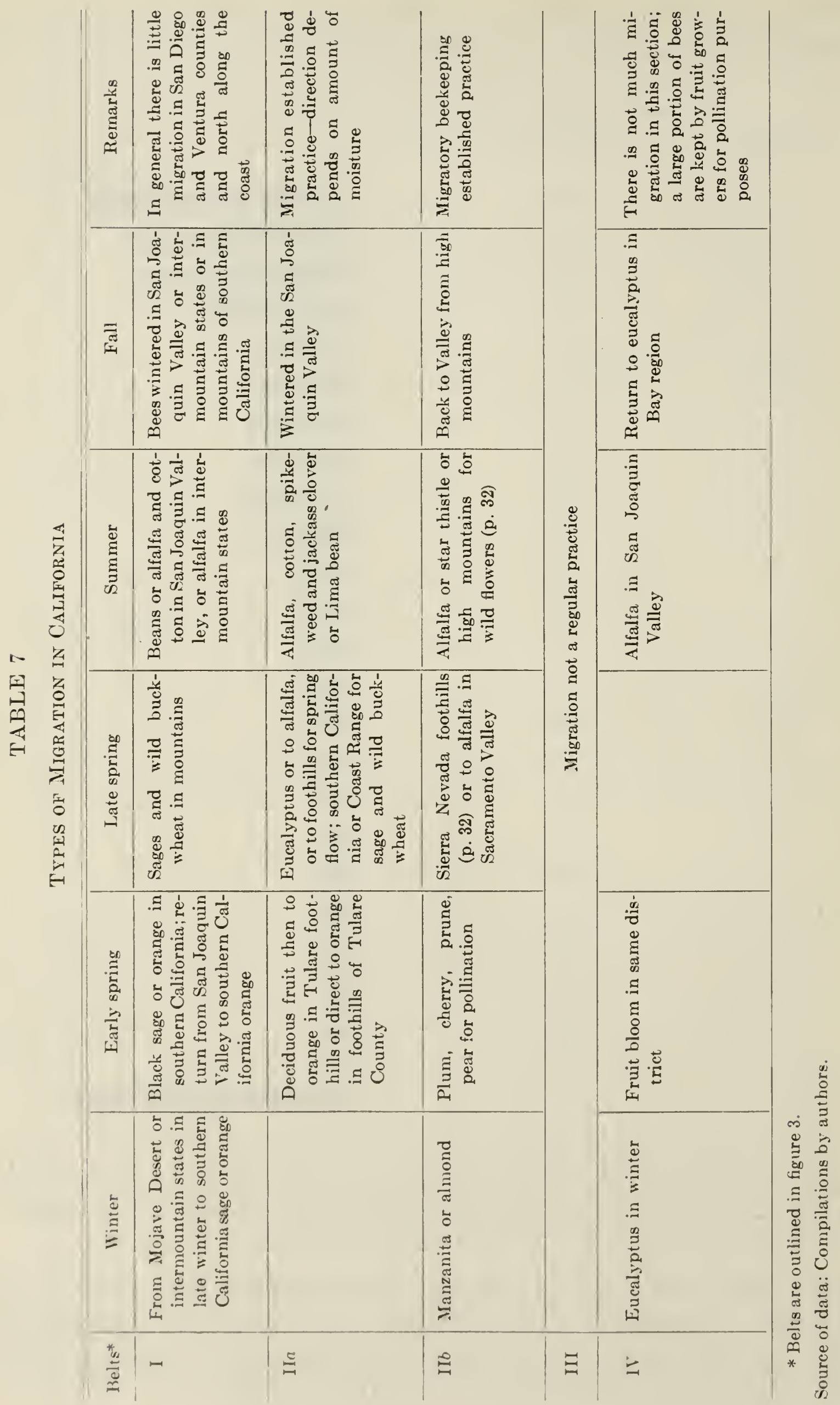


There is an annual movement of approximately 150,000 colonies in the state. About half of the migration takes place within county lines, the remainder being between counties and interstate. ${ }^{24}$ Migrations are at a minimum along the coast north of Ventura County and in the irrigated valleys east of the Sierra Nevada Mountains. A marked decrease in interstate migration took place in 1930 because of state embargoes on bees on combs for the prevention of the introduction of disease. However, recent experiments with combless package bees on trucks

\section{TABLE 8}

Migration of Colonifs of Bees in California, 1928-1932

\begin{tabular}{|c|c|c|c|c|c|}
\hline Yeat & \multicolumn{2}{|c|}{ Interstate } & Into counties & Intracounty & Total \\
\hline 1928. & 4,318 & 14,201 & 48,468 & 62,499 & 129,476 \\
\hline 1930. & 1,445 & 1,485 & 71,432 & 67,832 & 141,194 \\
\hline $1931 \ldots$ & 1,897 & 2,856 & 79,873 & 100,822 & 180,695 \\
\hline 1932. & 6,418 & 8,306 & 57,937 & 74,551 & 147,212 \\
\hline Five-year average. & 4,851 & 8,885 & 64,471 & 75,674 & 150,730 \\
\hline
\end{tabular}

Sources of data:

Todd, Frank E. Apiary inspection. California Dept. Agr. Mo. Bul. 19: 871-892. 1930.

Krebs, H. M. Annual Reports. California Dept. Agr. 1931-32. (Mimeo.)

indicate that this practice may be resumed. With an increased and more thorough knowledge of nectar flows in now little-frequented sections of the state, it seems reasonable to suppose that migratory beekeeping will increase in the future.

\section{NUMBER OF COLONIES PER BEEKEEPER IN CALIFORNIA}

In 1930, 60 per cent of the beekeepers in California had an average of 30 colonies per beekeeper. Such an average, however, is somewhat misleading for actually (table 9) but few beekeepers had this number. Slightly over 62 per cent had less than 10 colonies, and since the sample was based on registration returns it is likely that the percentage of all beekeepers in this group is even greater. Relatively more small apiaries escape registration than larger ones. Beekeepers operating less than 100 colonies comprised 91.5 per cent of all operators in the sample. It is of significance, however, that while 6 per cent of the operators had between 100 and 300 colonies, this group possessed 30 per cent of the total number

24 Todd, Frank E. Apiary inspection. California State Dept. Agr. Mo. Bul. 19: 871-892. 1930. 
of colonies in the sample. Only 2.5 per cent of the beekeepers owned more than 300 colonies but they possessed 36 per cent of all colonies included in the sample. The industry is concentrated in fewer hands than a mere cursory examination of the available data would indicate. It is probable

TABLE 9

Distribution of Beekeepers Based Upon the Number of Colonies per Beekeeper, Califfornia, 1930

\begin{tabular}{|c|c|c|c|c|c|}
\hline \multirow{2}{*}{$\begin{array}{l}\text { Number of colonies } \\
\text { per beekeeper }\end{array}$} & \multicolumn{5}{|c|}{ Number of beekeepers in } \\
\hline & $\begin{array}{c}\text { South coast } \\
\text { and chaparral } \\
\text { belt }\end{array}$ & $\begin{array}{l}\text { Sacramento- } \\
\text { San Joaquin } \\
\text { belt }\end{array}$ & $\begin{array}{c}\text { Trans- } \\
\text { mountain } \\
\text { belt }\end{array}$ & $\begin{array}{c}\text { Bay region } \\
\text { and cut-over } \\
\text { redwood area }\end{array}$ & State total \\
\hline $1-9 \ldots \ldots \ldots \ldots \ldots \ldots \ldots \ldots$ & 1,430 & 2,678 & 91 & 458 & 4,657 \\
\hline $10-19 \ldots \ldots \ldots \ldots \ldots \ldots \ldots \ldots \ldots \ldots$ & 390 & 455 & 24 & 84 & 953 \\
\hline $20-29 \ldots \ldots \ldots \ldots \ldots \ldots \ldots \ldots \ldots$ & 193 & 212 & 18 & 24 & 447 \\
\hline $30-39 \ldots \ldots \ldots \ldots \ldots \ldots \ldots \ldots \ldots$ & 111 & 97 & 12 & 13 & 233 \\
\hline $40-49 \ldots \ldots \ldots \ldots \ldots \ldots \ldots$ & 79 & 67 & 6 & 11 & 163 \\
\hline 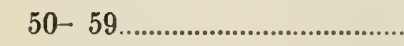 & 80 & 44 & 4 & 7 & 135 \\
\hline $60-69 \ldots \ldots \ldots$ & 49 & 30 & 6 & 4 & 89 \\
\hline $70-79$ & 46 & 23 & 6 & 3 & 78 \\
\hline $80-89$ & 36 & 22 & 4 & 3 & 65 \\
\hline $90-99$ & 14 & 20 & 2 & 2 & 38 \\
\hline $100-199 \ldots \ldots \ldots$ & 175 & 107 & 19 & 7 & 308 \\
\hline $200-299$ & 72 & 49 & 13 & 7 & 141 \\
\hline $300-399 \ldots \ldots \ldots$ & 35 & 31 & 7 & 2 & 75 \\
\hline $400-499 \ldots \ldots \ldots$ & 22 & 14 & 6 & .... & 42 \\
\hline 500 or over... & 27 & 29 & 13 & 1 & 70 \\
\hline Total....... & 2,759 & 3,878 & 231 & 626 & 7,494 \\
\hline
\end{tabular}

Source of data:

Computations by authors on basis of registrations reported by County Agricultural Commissioners of California.

that approximately 5 per cent of the beekeepers of the state produce 75 per cent of the crop.

The transmountain belt leads all other honey belts in the state in percentage of beekeepers owning more than 100 colonies. The south coast and chaparral belt, the greatest commercial section, ranks second, and the Bay region and cut-over redwood area has the smallest percentage.

\section{HONEY PRODUCTION}

The term "honey production" is used to denote the surplus honey removed from the hive by the beekeeper and represents only a small portion of the total quantity elaborated by the bees in a season. The needs of the colony for maintenance, feeding brood, and wax production vary with different conditions. While one or two nectar sourees usually supply the surplus, the minor honey plants contribute an important part of the maintenance. 
Production may vary greatly from season to season in any given locality. This is the result of differences in the condition of bees, the weather, and other factors influencing nectar secretion and management.

United States.-The number of colonies in a region is only a secondary index to the quantity of honey produced. Such production figures as are available are only approximations, but when they are taken over large

TABLE 10

Honfy Production by District's, United Sta'tes, 1928-1931

\begin{tabular}{|c|c|c|}
\hline Distriet & $\begin{array}{c}\text { A verage annual } \\
\text { honey } \\
\text { production, } \\
1928-1931\end{array}$ & $\begin{array}{l}\text { Share of total } \\
\text { production }\end{array}$ \\
\hline & $\begin{array}{l}\text { thousands of } \\
\text { pounds }\end{array}$ & per cent \\
\hline White Clover Belt... & 68,213 & 36.3 \\
\hline 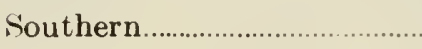 & 40,627 & 21.5 \\
\hline Texas................................ & 8,705 & 4.6 \\
\hline Plains area & 28,138 & 14.9 \\
\hline Pacific Northwest... & 5,891 & 3.0 \\
\hline California & 15,779 & 84 \\
\hline Intermountain .... & 18,310 & 9.7 \\
\hline 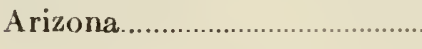 & 2,945 & 1.6 \\
\hline Total... & 187,968 & 100.0 \\
\hline
\end{tabular}

Source of data:

U. S. Dept. Agr. Bur. Agr. Econ. Honey No. 348. Market News Service, semimonthly report. Washington, D. C. 1932. (Mimeo.) Data for the above table are necessarily based on estimates and cannot be considered as more than a general picture of production in various districts.

areas and considerable periods of time some idea can be gained concerning the relative importance of the various sections. Estimates of total honey production in 1900 and 1914 were 100,000,000 and 124,000,000 pounds respectively. Stimulated by war-time demand, production reached a peak of approximately $222,000,000$ pounds in 1922 . Estimates for the four years 1928-1931 show a decided decrease in production to about $188,000,000$ pounds. This tendency has been a fortunate one for the industry as a whole.

Over one-third of the honey produced in the United States in 1928 to 1931 came from the White Clover Belt (fig. 2). The southern district contributed over a fifth, while the intermountain and California districts combined produced less than a fourth. The last two districts contain less than 7.5 per cent of the nation's population. The ratio of honey production to population is larger in the West than in the East, which necessitates the removal of a considerable portion of the crop from the former to the latter area (fig. 10). That bee culture is not a "frontier" industry is clearly shown by the fact that 73 per cent of the honey crop is produced in the states containing 55 per cent of the population. 
The lack of continuous accurate data makes changes in production in the various honey districts difficult to analyze. In comparing estimates for the eleven years 1913-1923 with those for the years 1928-1931, the greatest relative increase is noted for the White Clover Belt, Plains area, and Arizona, while a relative decrease is indicated for the southern and California districts. The same shift is indicated if the census data for 1919 and 1929 are compared. Year-to-year variation in production might

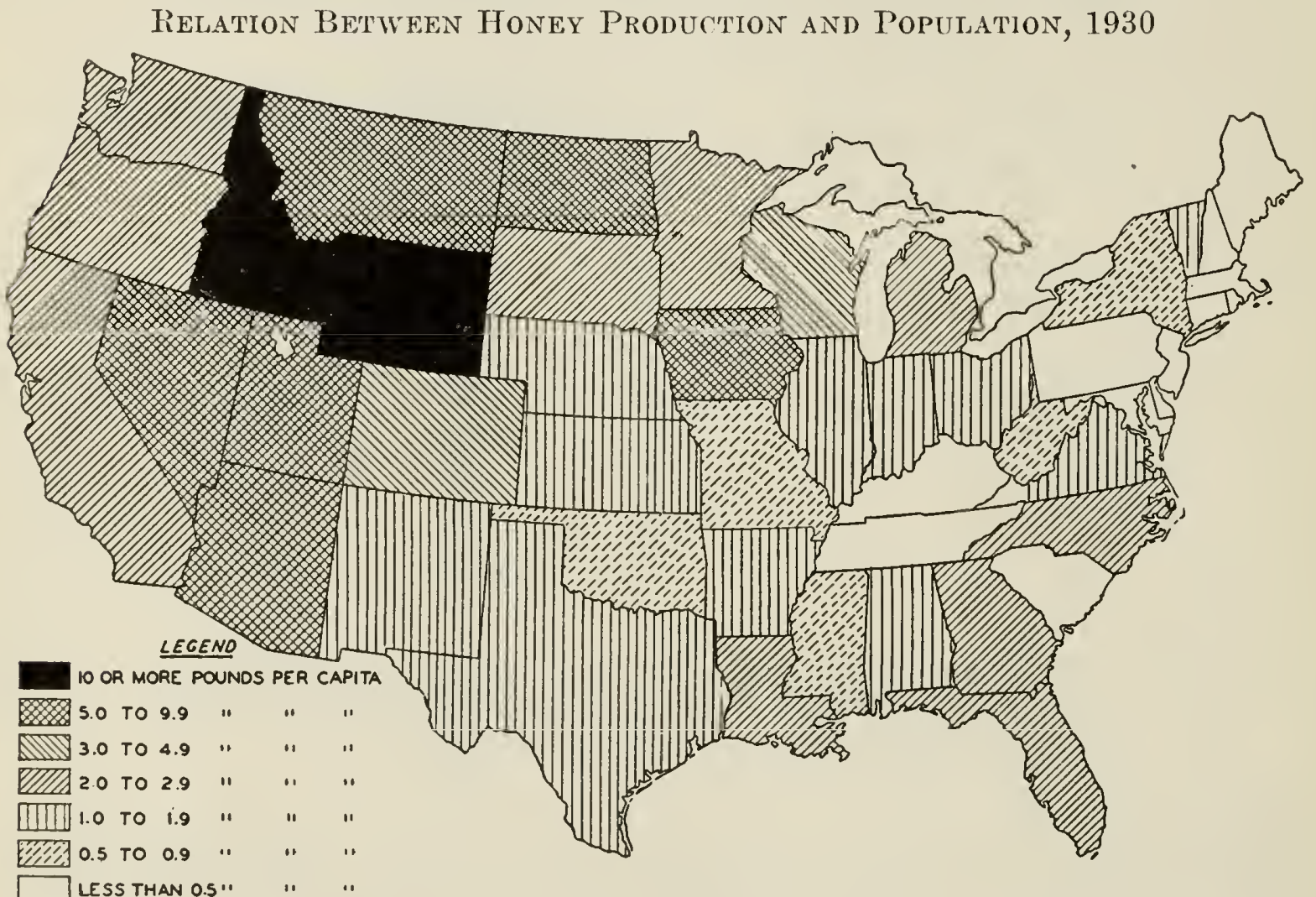

Fig. 10.-In proportion to population the areas of greatest production are west of the Mississippi River. The largest honey surplus is found in this area. The Middle Atlantic and New England states produce less honey in proportion to the population than any other part of the United States. This latter area is the largest market for honey within the United States. (Data compiled by authors by averaging the estimated production of honey for each of the several states for 19281931 and dividing these data by the populations of the states as of April 1, 1930.)

account for this change, but it is known that the increased cultivation of sweet clover in many of the areas showing increased production has increased their potential honey-producing possibilities.

California.-California is the leading honey-producing state, followed by six states in the White Clover Belt and Texas. In interpreting production data by states, it is to be noted that areas vary widely, e.g., California and Rhode Island.

While accurate data on the amount of honey produced in California prior to 1927 do not exist, honey production during the third decade of the century was at least double what it was during the first decade. The 
stimulus to increase was largely due to high prices paid during the War period. However, during the five years 1927-1931 there was a continuous decline in production (table 11).

Over the six-year period 1927-1932, the south coast and chaparral belt, where greatest concentration of the state's bee industry occurs, produced almost 49 per cent of the state's honey (table 11). Next in importance is the Sacramento-San Joaquin belt, where over a relatively

TABLE 11

Estimated Total Production of Honey and Distribution by Belts, Califoria, $1927-1932$

\begin{tabular}{|c|c|c|c|c|c|}
\hline \multirow{2}{*}{ Year } & \multirow{2}{*}{$\begin{array}{l}\text { Estimated total } \\
\text { production, thou- } \\
\text { sands of pounds, } \\
\text { i.e., } 000 \text { omitted }\end{array}$} & \multicolumn{4}{|c|}{ Per cent production } \\
\hline & & Belt I & Belt II & Belt III & Belt IV \\
\hline 1927. & 17,149 & 45.8 & 45.2 & 8.1 & 0.9 \\
\hline $1928 \ldots .$. & 17,047 & 46.2 & 43.6 & 9.2 & 1.0 \\
\hline $1929 \ldots$ & 15,960 & 41.7 & 44.1 & 11.0 & 3.2 \\
\hline $1930 \ldots$ & 15,526 & 58.0 & 33.6 & 7.7 & 0.7 \\
\hline $1931 \ldots \ldots$ & 14,378 & 50.5 & 35.2 & 13.5 & 0.8 \\
\hline $1932 .$. & 17,612 & 52.1 & 40.1 & 6.8 & 10 \\
\hline Six-year average.... & 16,279 & 48.9 & 40.5 & 9.3 & 1.3 \\
\hline
\end{tabular}

Sources of data:

Production data from: U. S. Dept. Agr. Bur. Agr. Econ. Honey No. 348. Market News Service semimonthly report. Washington, D. C., 1932. (Mimeo.)

Per cent production: Calculations by authors.

wide area about 40 per cent of the annual crop is produced. Considering the relatively small population of the transmountain belt, the contribution of over 9 per cent of the crop is an important factor on commercial honey markets. The Bay Region and cut-over redwood area have contributed an insignificant amount.

Territorial Possessions of the United States.-Two territories of the United States, Puerto Rico and the Hawaiian Islands, are important contributors to the honey markets of this country. Hawaiian honey production is of significant interest to the California producer since much of this honey comes to California ports either to be "entered for consumption" or for reëxport. Shipments to continental United States in 1932 amounted to $1,653,000$ pounds. ${ }^{25}$ The average yearly shipments over the ten-year period 1923-1932 were 1,536,000 pounds.

The most important floral source of honey on the islands is the algaroba tree, Prosopis juliflor ${ }^{26}$ which produces a desirable, light-colored

25 U. S. Dept. Com. Monthly Summary of Foreign Commerce of the United States, June and December issues.

26 Van Dine, D. L., and Alice R. Thompson. Hawaiian honeys. Hawaii Agr. Exp. Sta. Bul. 17:1-21. 1918. 
product. Honeydew honey is also produced in Hawaii. This is usually dark in color and disagreeable in flavor, and, alone or mixed with other honey, it brings very general adverse discrimination.

The 1930 Census reports 14,555 colonies of bees in Hawaii, which corresponds rather closely to the 1920 data. This number is approximately the same as that for Fresno or Imperial counties.

Beekeeping in Puerto Rico was developed following the American occupation (1898) and Puerto Rican honey now occupies a fairly important place on certain honey markets in eastern United States. There are numerous nectar sources on the island of which the guama, Inga laurina, guava, Inga vera, and royal palm, Roystonea regia are listed by Phillips as the most important. ${ }^{27}$

Puerto Rican honeys are characteristically of an amber color. Where a light honey is preferred for table purposes, they tend to be diverted into baking and similar uses.

Production methods and technique are rather well advanced in Puerto Rico and modern equipment is in general use. The 1930 Census reports 24,444 colonies of bees on the island, which, however, is but slightly more than half the number reported by the 1920 Census. This drastic decline has been attributed to the low price of honey, the destructive effect of the hurricanes of 1926 and 1928, and to a degeneration of the stock in use on the island. ${ }^{28}$ Puerto Rican honey enters the United States in largest amounts at New York City.

Seasonal Production.- The economy of honey production has its basis in the successive bloom of a great variety of cultivated and wild plants. Many plants, not sources of surplus honey, make important contributions of nectar and pollen which stimulate the colony to increase in numbers of bees. This builds up colony strength and enables the bees to take advantage of major honey flows and to maintain the colony through the winter and other periods of food scarcity. The succession of bloom in a given district will be in general the same, but the blooming date of a given plant within the district may vary within narrow limits in the same season, particularly when the area covered is large and encompasses a great diversity of climate.

In figure 11 the usual honey-flow periods of the prineipal honey plants ${ }^{29}$ of the United States are depicted, using districts as a basis for

27 Phillips, F. F'. Puerto Rican beekeeping. Puerto Rican Agr. Exp. Sta. Bul. 15: 11-12. 1914.

$2 \times$ Isetter to the authors from David $\Lambda$. Rodriquer, Apiculturist, Tusular Experiment Station, Piedras, P. R. July 29, 1932.

29 Some of the minor flows ale shown beeause of their inportance in huilding up rolony strengtli, polliuation, and package-lee production (page 99). 
their duration. While this figure indicates for the country as a whole an ahmost coutinuous flow throughout the year, no single locality is so endowed. There appears to be a comparative dearth of flows from August to A pril. The earliest important flows are from orange, sage (salvia), tupelo, and gallherry in April, followed by mesquite, horsemint and alfalfa (California and Arizona) in May. June, July, and August are the most important honey months when white clover, sweet

\section{TABLE 12}

Estimated Seasonal Production of Honey in Districts of the Uniteid States, 1913 то 1924

\begin{tabular}{|c|c|c|c|c|}
\hline \multirow{2}{*}{ District } & \multicolumn{4}{|c|}{ Per cent of crop obtained } \\
\hline & $\begin{array}{l}\text { Mar. 1- } \\
\text { A pr. } 30\end{array}$ & $\begin{array}{l}\text { May 1- } \\
\text { June } 30\end{array}$ & $\begin{array}{l}\text { July 1- } \\
\text { Aug. } 31\end{array}$ & $\begin{array}{c}\text { Sept. 1- } \\
\text { Feb. } 28\end{array}$ \\
\hline California... & 25 & 35 & 34 & 6 \\
\hline Arizona .................. & 16 & 44 & 34 & 6 \\
\hline Southern........................ & 16 & 50 & 20 & 16 \\
\hline 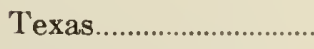 & 11 & 54 & 20 & 14 \\
\hline White Clover Belt.... & 0 & 39 & 47 & 14 \\
\hline Plains area...................... & 0 & 38 & 49 & 13 \\
\hline Pacific Northwest & 0 & 30 & 63 & 7 \\
\hline Intermountain ...... & 0 & 11 & 81 & 8 \\
\hline United States... & 9 & 40 & 39 & 12 \\
\hline
\end{tabular}

Source of data:

Computations by authors on the basis of: U. S. Dept. Agr. Bur. Agr. Econ. Honey. No. 104, 1922; No. 149, 1923. Market News Service, semimonthly reports. Washington, D. C. (Mimeo.)

clover, alfalfa, and basswood are produced. Honey flows from like plant sources are earlier and of shorter duration in the South than in the North. Fall flows are of importance because they are depended upon to put the bees into proper condition for wintering, while the spring flows serve to develop the colony for honey storage.

Honey production in the United States is highly seasonal, almost 80 per cent of the crop being produced in the four months, May to August (table 12). Only about 9 per cent of the crop is produced before May 1, but it is important in the establishment of early wholesale prices. Approximately 50 per cent is produced before July 1 and approximately 88 per cent by September 1. While the production after this latter date approximates 12 per cent, it is of relatively minor consequence in the market situation.

Between districts there is a wide variation in the season of production. Honey produced before May 1 comes from the southern, Arizona, Texas, and California districts. That produced in California probably has the greatest influence on the larger wholesale markets. The bulk of the crop 


\begin{tabular}{|l|l|l|l|l|l|l|l|l|l|l|l|}
\hline Jan. & Feb. & Mar & Apr & May & June & July & Aug. & Sept & Oot. & Nov. & Deo. \\
\hline
\end{tabular}

Eucalyptus

Iaple, titi, willow, elm

Fruit bloom

Orange

Fruit bloom

Tupelo

Orange

Sages

Gallberry

Mesquite and catclaw

White clover

Vine maple

Fruit bloom

Tulip tree

Fruit bloom

Horsemint

Vetches

Alfalfa

Figwort

Alfalfa

White clover

White cloveralsike

White cloveralsike

Alfalfa

Wild buckwheat

Lima bean

Sweet clover

Sourwood

Sweet clovers

Sweet clovers

Basswood

Sweet clover

Cotton

Fireweed

Star thistle

Buckwheat

(cultivated)

Heartsease

Rabbit brush

Spanish needle

Algaroba

(keawe)

\section{DISTRICTS}

California, according to elevation

California, various

species

Southern

California

Florida

Southern

Southern

California

California

Southern

Texas, Arizona, California (two flows in Texas)

Southern

Pacific Northwest

Pacific Northwest

Southern

White Clover Belt

Texas

Pacific Northwest west of Cascades:

Imperial Valley, Arizona

Pacific Northwest, fireweed area

San Joaquin and Sac. rainento valleys,

California

Plains area

Pacific Northwest west of Cascades

White Clover Belt

Intermountain, Pacific Northwest

California

California

Southern, Texas

Southern

Plains area

Intermountain, Pacific Northwest

White Clover Belt

White Clover Belt

Southern, Texas, $A$ izorra, Califormia

Pacific Northwest

California

White Clover Belt

White Clover Belt and Plains area

Pacific Northwest, California, intermountain

plains area

Hawaiian Islands

Fig. 11.- Honey flows start with those in California and southern districts. A succession of flows then oceurs, the larger part coming during the late spring and summer months. During the six months beginning with October there are few flows except in California. A eheck list of scientific plant names is given in table 34. (Data compiled by authors with the assistance of the phenological records furnished through the courtesy of the U. S. Dept. Agr. Bee Culture Laboratory, Washington, D. C.) 
in these districts is produced before July 1, while in the White Clover Belt, Plains area, and the Pacific Northwest and intermountain districts the heaviest production is during July and August.

Of the California crop about 60 per cent is produced before July 1 , while the intermountain and Pacific Northwest districts, which compete most directly on the California markets, produce 70 and 89 per cent respectively, of their crops after that date (table 12). No definite information is available concerning the proportion of the Hawaiian crop produced in each period, but it appears probable that about 50 per cent is produced by July 1 .

Even though extracted honey is but a semiperishable product, the arrival of new-crop honey on the market has a special appeal to the consumer and affects the price of the old crop on hand (page 61). This is particularly true of the more perishable comb honey. Therefore the approximate date of arrival on the market of new-crop honey from different sources becomes a matter of importance in marketing. California orange is the first new-crop honey to arrive on the market, followed closely by Florida orange, California sage, and mesquite and catclaw. All of these appear about May 1. New-crop honey (alfalfa, sweet clover, alsike, and white clover), from which most of the comb honey is produced, arrives during June; new-crop honeys arriving after that month are from comparatively minor sources. Indications are that the new-crop) Hawaiian honey reaches continental United States in September.

Production per Colony.-For the United States as a whole, census returns show a per-colony honey production of $15,16,16$, and 27 pounds for 1899, 1909, 1919, and 1929, respectively. These are representative of farm yields only and commercial per-colony production is considerably higher according to records obtained from several thousand beekeeper's by the Division of Crop Estimates of the United States Department of Agriculture for the years 1913 to 1924 . Estimates of per-colony production for both farm and commercial beekeepers (table 13) fall between estimates of per-colony yields obtained by farm producers and those obtained by specialized beekeepers.

A high degree of yearly fluctuation in per-colony production oceur's in different districts. This variation as between districts is considerably greater than for the country as a whole, since it is seldom that either favorable or unfavorable conditions occur in all districts in the same year. From a marketing standpoint it is apparent that wide fuctuations in yields between different areas of the country necessitate a more flexible marketing structure than is required for many other commodities.

Data on per-colony production in California were obtained by the 
authors from beekeepers maintaining records of such production (table 14). Enumerations for 1897 to 1909 are based upon a limited number of lecords, but following the latter date sufficient records were obtained to give a satisfactory picture of per-colony production in the state. It is probable that the figures given are somewhat higher than the average for all beekeepers, since a majority of those supplying information were experienced and well-established operators.

TABLE 13

Average Estimated Production of Honey per Colony, Uniten states.

Commercial Producers, Average 1913-1924, All Producers,

YEARLY AND AVERAGE, 1928-1931

(Pounds per colony)

\begin{tabular}{|c|c|c|c|c|c|c|c|c|c|}
\hline Year & $\begin{array}{c}\text { White } \\
\text { Clover } \\
\text { Belt }\end{array}$ & \begin{tabular}{|l} 
South- \\
ern \\
district
\end{tabular} & $\begin{array}{c}\text { Plains } \\
\text { area }\end{array}$ & $\begin{array}{c}\text { Inter- } \\
\text { moun- } \\
\text { tain } \\
\text { district }\end{array}$ & $\begin{array}{c}\text { Cali- } \\
\text { fornia } \\
\text { district }\end{array}$ & $\begin{array}{l}\text { Texas } \\
\text { district }\end{array}$ & $\begin{array}{l}\text { Pacific } \\
\text { North- } \\
\text { west } \\
\text { district }\end{array}$ & $\begin{array}{l}\text { Arizona } \\
\text { district }\end{array}$ & $\begin{array}{l}\text { United } \\
\text { States }\end{array}$ \\
\hline
\end{tabular}

Commercial producers

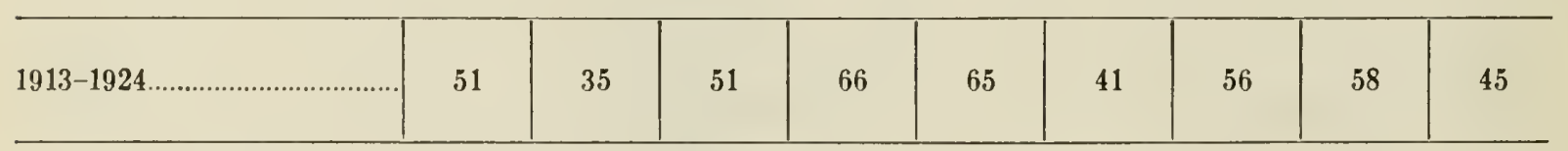

All producers

\begin{tabular}{|c|c|c|c|c|c|c|c|c|c|}
\hline 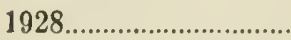 & 41 & 38 & 59 & 79 & 45 & 40 & 34 & 60 & 35 \\
\hline 1929. & 32 & 26 & 59 & 61 & 41 & 40 & 32 & 55 & 43 \\
\hline $1930 \ldots \ldots \ldots \ldots \ldots \ldots \ldots \ldots$ & 34 & 26 & 48 & 57 & 41 & 30 & 44 & 40 & 43 \\
\hline \multirow[t]{2}{*}{$1931 \ldots$} & 39 & 33 & 49 & 39 & 38 & 32 & 37 & 35 & 40 \\
\hline & - & - & - & 一 & - & 一 & 一 & 一 & $一$ \\
\hline A verage 1928-1931.. & 36 & 31 & 54 & 59 & 41 & 35 & 37 & 42 & 40 \\
\hline
\end{tabular}

Sources of data:

1913-1924: U. S. Dept. Agr. Crops and Markets. 1 (Supplement 12) : 424. 1924.

1928-1931: Calculations by authors based upon estimated number of colonies and estimated production. U. S. Dept. Agr. Bur. Agr. Econ. Honey. No. 348. Market News Service, semimonthly report. Washington, D. C. 1932. (Mimeo.)

There has been a marked diminution in per-colony production in California since 1915. This is particularly well illustrated by examination of five-year averages (table 15), and it followed upon a rather steady increase in yield prior to that time.

Apparently some association exists between per-colony production and rainfall (fig. 12 and table 15). Interpretations must be made with caution but an examination of the data as presented would indicate that the trend in per-colony yields is similar to that of rainfall. This association is not close, however, from the standpoint of yearly fluctuations. 'Temperature, atmospheric pressure, humidity, winds, sunshine, and soil moisture, in their effect upon both bees and plants in different combinations, undoubtedly make for considerable variations unexplained by 


\section{TABLE 14}

('ommercial Production of Honey per Colony, California, 1911-1932 (Pounds per colony)

\begin{tabular}{|c|c|c|c|c|c|}
\hline \multirow{2}{*}{ Year } & \multirow{2}{*}{ State } & \multicolumn{2}{|c|}{ South coast and chaparral } & \multirow{2}{*}{$\begin{array}{l}\text { Sacramento- } \\
\text { San Joaquin } \\
\text { belt, } \\
\text { II }\end{array}$} & \multirow{2}{*}{$\begin{array}{l}\text { Trans- } \\
\text { mountain } \\
\text { belt, } \\
\text { III }\end{array}$} \\
\hline & & $\begin{array}{l}\text { Beltt* } \\
\text { I } a\end{array}$ & $\begin{array}{c}\text { Belt } \dagger \\
\mathrm{I} b \text { and I } c\end{array}$ & & \\
\hline $1911 \ldots \ldots \ldots \ldots \ldots$ & 59 & 53 & 58 & 65 & 65 \\
\hline $1912 \ldots \ldots \ldots \ldots$ & 59 & 68 & 63 & 55 & 73 \\
\hline $1913 \ldots \ldots$ & 63 & 55 & 69 & 65 & 65 \\
\hline $1914 \ldots$. & 77 & 95 & 73 & 119 & 65 \\
\hline $1915 \ldots \ldots \ldots$ & 82 & 85 & 58 & .95 & 85 \\
\hline $1916 \ldots \ldots$ & 75 & 59 & 83 & 75 & 85 \\
\hline $1917 \ldots \ldots$ & 55 & 43 & 65 & 49 & 85 \\
\hline $1918 \ldots \ldots \ldots \ldots \ldots \ldots$ & 63 & 55 & 73 & 53 & 75 \\
\hline $1919 \ldots \ldots \ldots \ldots$ & 71 & 63 & 75 & 73 & 85 \\
\hline $1920 \ldots \ldots$ & 85 & 108 & 68 & 95 & 85 \\
\hline $1921 \ldots \ldots \ldots \ldots$ & 54 & 53 & 64 & 55 & 65 \\
\hline $1922 \ldots \ldots$ & 68 & 73 & 59 & 95 & 131 \\
\hline $1923 \ldots \ldots$ & 41 & 26 & 59 & 33 & 73 \\
\hline $1924 \ldots \ldots \ldots \ldots$ & 49 & 35 & 58 & 49 & 75 \\
\hline $1925 \ldots \ldots$ & 54 & 45 & 62 & 58 & 95 \\
\hline $1926 \ldots \ldots \ldots \ldots$ & 64 & 68 & 59 & 79 & 83 \\
\hline $1927 \ldots \ldots \ldots \ldots$ & 48 & 37 & 58 & 58 & 67 \\
\hline $1928 \ldots \ldots$ & 47 & 49 & 59 & 55 & 75 \\
\hline $1929 \ldots \ldots \ldots \ldots$ & 47 & 42 & 48 & 59 & 68 \\
\hline $1930 \ldots \ldots \ldots \ldots \ldots$ & 53 & 61 & 51 & 57 & 73 \\
\hline $1931 \ldots \ldots \ldots \ldots \ldots$ & 39 & 36 & 56 & 32 & 65 \\
\hline $1932 \ldots \ldots \ldots \ldots$ & 62 & 80 & 62 & 63 & 48 \\
\hline
\end{tabular}

* Belt I $a$ : Sage and orange territory, Los Angeles, Riverside, Orange, and San Bernardino counties.

$\dagger$ Belt I $b$ and Ic: Sage territory from San Diego northward to Monterey County, excluding Orange and Los Angeles counties.

Sources of data:

Calculations by authors on the basis of information furnished by beekeepers of California.

TABLE 15

Average Annual Per-Colony Yield of Honey and Average Annual Precipitation, for California, Five-Year Periods from 1897 то 1931

\begin{tabular}{|c|c|c|}
\hline Five-year periods & $\begin{array}{l}\text { A verage yield } \\
\text { of honey } \\
\text { per colony, } \\
\text { in pounds }\end{array}$ & $\begin{array}{l}\text { Average } \\
\text { precipitation, } \\
\text { in inches }\end{array}$ \\
\hline $1897-1901 \ldots \ldots$ & 37.0 & 18.73 \\
\hline $1902-1906 \ldots \ldots$ & 55.8 & 27.12 \\
\hline $1907-1911 .$. & 66.0 & 27.91 \\
\hline $1912-1916 \ldots \ldots$. & 71.2 & 29.45 \\
\hline $1917-1921 \ldots \ldots$ & 65.6 & 22.97 \\
\hline $1922-1926 \ldots \ldots .$. & 55.2 & 21.67 \\
\hline $1927-1931 \ldots \ldots \ldots$ & 46.8 & 1880 \\
\hline
\end{tabular}

Sources of data:

Average yield of honey per colony reported to authors by beekeepers in state. See table 23 .

Average precipitation from: U. S. Dept. Agr. Weather Bur. Comparative annual data for the state. Climatological data. California section 35 (13). 1931. 
variations in rainfall itself. Moreover, distribution as well as amomnt of rainfall is of importance.

Observations over a three-year period at the Texas Agricultural Experiment Station ${ }^{30}$ on humidity, rainfall, wind movement, light conditions, and barometric pressure indicated that there was no correlation

Average Annual Precipitation and Calculated Annual Yield of Honey per Colony, California, 1900-1932

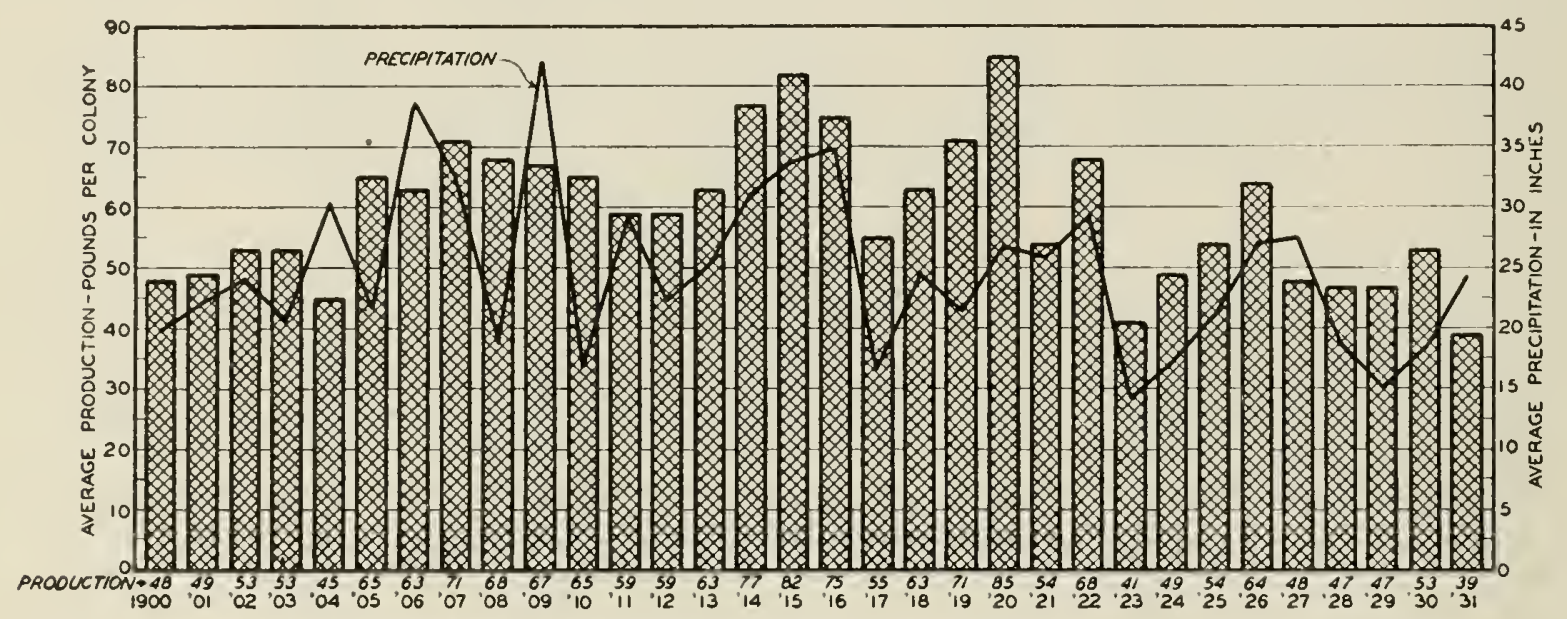

Fig. 12.- It is highly probable that there are many factors in addition to the annual amount of precipitation which influence the per-colony yield. The above indicates that since 1915 the calculated per-colony yield has been downward. Precipitation in the state has shown a distinct decline. (Data from table 14 and U. S. Dept. Agr. Weather Bur. Comparative anuual data for the state. Climatological data. California Section 35 [13]. 1931.)

between these on a yearly basis and the behavior of bees. Their investigators were of the opinion, however, that "accumulated rainfall and temperature as well as the time of occurrence of maximums, had much more to do with the actions of bees and plants than the general average of weather conditions."

Aside from climatic conditions, it may be noted that changes in natural vegetation, the cultivated area, and the nature of cultivated crops undoubtedly make for variations in per-colony production. Overstocking in some sections has brought decreased yields at times and differences in per-colony production between different apiaries may result from fires, spray poisoning, and numerous other factors. It is a safe conclusion that over a period of years high prices, by encouraging good management, have a definite effect on yields.

30 Texas Agricultural Experiment Station. Forty-third Amual Report 1930:87. 


\section{HONEY CONSUMPTION IN THE UNITED STATES}

Estimates of honey production for 1928-1931 (table 10) averaged $187,968,000$ pounds. As the net exports for continental United States for the same period averaged slightly over $4,000,000$ pounds, approximately $184,000,000$ pounds, or slightly over 1.5 pounds per capita, were left for domestic consumption. That the consumption is less than 2.0 pounds per capita is partially substantiated by Rasmussen. ${ }^{31}$ Evidently consumption increases in moving from east to west. The high per-capita producing states (fig. 10) are evidently the high per-capita consuming states. One of the significant features of the data from the survey by Rasmussen was the per-capita consumption of 2.4 pounds of honey among San Francisco and Oakland families studied as compared with 1.0, 1.9, and 2.2 pounds for New York, Chicago, and Kansas City, respectively. It is highly probable that the per-capita consumption in Los Angeles is even greater. The proportion of comb to extracted honey consumed is greater in the Middle West than in either the East or Far West. The Middle West is also the region of greatest comb-honey production. A larger percapita consumption among rural than among urban people is indicated.

The per-capita consumption appears small, especially to producers of honey, who, in most instances, probably consume several times the average quantity. To increase the per-capita consumption of any foodstuff is a difficult task, and, if the consumption of one foodstuff is increased, the probabilities are that the consumption of another will be decreased. Estimates by the authors indicate that over the past two decades there has been slight change in the per-capita consumption of honey.

\section{PRICES AND PURCHASING POWER ${ }^{32}$ OF HONEY}

Producers' Prices for Extracted and Comb Honey, California.-A continuous series of comparable honey prices over a period of years is difficult to obtain. Several series of prices are listed because they may prove to be of use in price analysis, as well as to beekeepers and students of the industry.

Over 200 producers in all sections of the state have furnished the prices obtained for their honey crops over a series of years. Two checks have been used in connection with these data. Since 1918 the Market

31 Rasmussen, M. P. Some facts concerning the production and marketing of honey. New York Agr. Col. (Cornell) Ext. Bul. 221:1-110. 1932.

32 The fluctuations in prices shown in table 16 and under the term "price" in many of the tables and figures of this bulletin represent price changes that have been due to two sets of causes: one, the changing value of the dollar; the other, 
News Service of the United States Department of $A$ griculture has been keeping producers informed on prices prevailing for various types of honey in California. 'Through the kindness of several large wholesalers of honey, an additional check on these prices has been obtained.

In table 16 a range and an average of prices paid producers for orange, alfalfa, sage, and star-thistle honey are given. The range paid for orange honey includes all white grades (white, water-white, extra white to white), which in part accounts for the comparatively wide variation in price. Prices received at any one time may be widely different from those frrevailing during another period of the same year, especially when prices are rising or declining rapidly. The average (table 16) is not weighted owing to the lack of data on volume of sales.

On account of the many different sources, the fluctuating supplies, the varying colors, etc., it is futile to compile a price representative of all honey in the state. The problem is somewhat akin to that of compiling a price on wool which also displays a wide variety of characteristics. ${ }^{33}$

Prices of honeys, such as orange, sage, and star thistle, which are largely used for table purposes, show a different behavior from some of those of which a considerable portion are used in manufacturing, e.g., California alfalfa. 'T'he prices of orange honey from 1910 to 1915, with the exception of one year, 1914, were relatively stable. This was the case with wholesale commodity prices and with wholesale honey prices in different sections of the country. During 1914 orange-honey prices dropped along with the prices of honey elsewhere in the United States. During 1916 and 1917 wholesale prices of orange honey did not rise so rapidly as general wholesale prices. In 1918, however, orange-honey

changes in the supply of, and the demand for, the particular product under consideration in the United States and in California.

The supply of money and eredit from 1914 to 1920 increased faster than the accompanying increase in the volume of trade. Largely for this reason, the value of money, or its purchasing power, fell. As a result of this decline in the value of money, at least two dollars were necessary in 1918, 1919, and 1920 to buy goods that, in general, could have been bought for one dollar in 1911, 1912, 1913, 1914, and 1915. 'This being the case, the dollars which the beekeeper received in 1918, 1919 , and 1920 were worth, in general purchasing power, less than half as much as those which he received and spent during the pre-war years.

In order to compute purchasing power, changes in the value of the dollar have lieen eliminated by the following method: The data in table 16 show the estimated actual prices received for honey. Columns 3, 7, 11, and 15 in table 16 show these actual prices expressed in terms of percentages of the 1910-1914 average. The latter relatives, or pereentages, of the 1910-1914 average price are then divided by the last column in table 16-the all-commodity index of wholesale prices-and columns $4,8,12$, and 16 of this table express the purchasing power of a definite unit of honey in terms of the average value or purchasing power during the years 1910-1914.

:3 Voorhies, Wdwin C:, and W. W. Schneider. Feonomic aspects of the sheep industry. Califormia Agr. Exp. Sta. Bul. 473:1-173. 1929. 


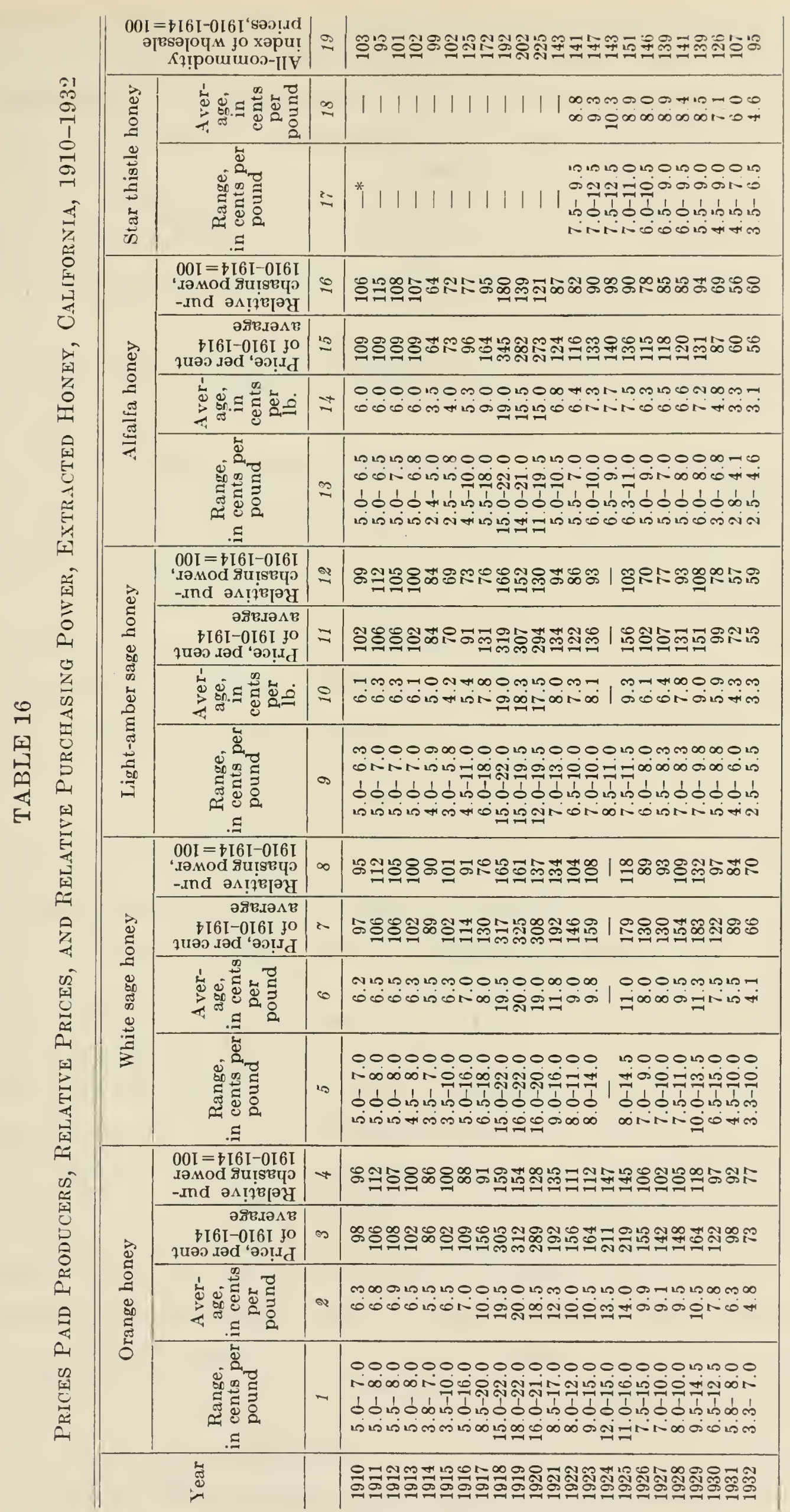


prices were above general wholesale prices, and in 1919 a peak was reached; they were triple those prevailing during the pre-war period (table 16). Beginning in 1920, prices for orange honey declined rapidly, even more rapidly than general wholesale prices. If producers' prices of orange honey in 1920, 1921, and subsequent years are compared with those prevailing during the peak years of 1919 and 1920, they appear to be unduly deflated. However, in terms of 1910-1914 dollars, orange honey was higher in price from 1918 to 1929 than it was during the pre-war period (table 16).

During 1924 and 1925 there was a considerable upswing in producers' prices of orange and other table honeys. In 1930 a decline set in and orange-honey prices went to relatively lower levels than those for general commodities (table 16). This relative position continued through 1931 and 1932. If orange-honey prices and purchasing power were calculated in terms of 1926 dollars, slightly different results would be obtained. These producers' prices, however, are fairly stable, as compared with those of many other agricultural commodities.

Sage-honey prices have been divided into those for "white sage" and "light-amber sage" on account of the rather clear line of demarcation hetween the two sets of price data. Light-amber grades have their floral source not only in sage but in other plants as well, and for this reason they are darker in color, although they are natural blends.

Since 1919 wholesale price fluctuations of white-sage honey have been greater than those of orange honey on account of the fluctuations in supply. General price movements of these two honeys have been similar. Light-amber sage has declined more in price front the peak year 1929 than either orange or white-sage honey.

Star-thistle honey first appeared in marketable quantities in 1922. Both the price range and average price have fluctuated less from year to year than those of other California honeys studied. Prices dropped in 1930,1931 , and 1932 , but not relatively so much as those of other honers. Among others, there are two reasons which may explain the fairly steady price. Star thistle blends well with alfalfa honey, and, as a result, the blend sells for a higher price than the straight alfalfa. Also on account of the German diastase-content requirement, there was a considerable demand for export purposes (page 72). Had this honey been available in quantity over a long period of time its price history probably would have been more similar to that of either orange or sage honey than to that of California alfalfa honey.

California alfalfa-honey prices rose to relatively higher levels than any of the other varieties of honey listed during the War period. The 
drop inmediately afterwards was much greater than was the case with orange or white-sage honey. For the period 1921-1932, California alfalfa-honey prices have been relatively low as compared with those of orange, sage, or star-thistle honey or with general wholesale commodity prices.

A series of prices from a sufficiently large number of comb-honey producers is not available so that only the most general conclusions with reference to price movements are justified. So far as California is concerned, the most comparable prices on white-sage comb honey are those obtained from quotations published by the Market News Service of the United States Department of Agriculture and the Federal-State Marketing Service.

The supply of this type of comb honey is extremely limited and doubtless accounts for the relatively high level of prices prevailing from 1926 to 1931. Intermittent quotations indicate that the price of this product did not rise relatively so high as that of extracted honey during the War years. During the latter period wholesale prices were approximately twice those existing during the years 1910-1914. A limited number of prices obtained from comb-honey producers in different sections of the state indicate a similar movement. However, the state's comb-honey prices have not experienced so great a decline from the peak War years' prices as have wholesale prices of extracted honey.

Retail Prices.-Retail prices are not available over a period of year's for California. Series of retail prices both for extracted and comb honey have been compiled for the United States as a whole, and in figure 13 the averages of producers' and retail prices for 1926 are each taken as equaling 100. Comparisons can therefore be made between retail and producers' prices for the United States, but not for California. As with other commodities, fluctuations in retail honey prices are less numerous than in those paid to producers. A significant lag in retail honey prices as compared to those of producers is apparent (fig. 13). While the latter prices showed a definite downward movement from 1925 through 1932, retail prices did not follow with a decline until 1928, and only since 1930 has there been any really pronounced drop in keeping with lowered producers' prices. From the producers' standpoint, this narrowing of the spread between the two sets of prices was a favorable development, so far as lowered retail prices react favorably upon consumption. A stabilizing influence thus becomes operative in the honey market which may tend to check further declines in producers' prices.

In comparing relative retail honey prices with the relative retail prices of all food articles, a close association between the two is strik- 
ingly apparent. From 1923 to early 1925 honey prices were somewhat above the level of the general food prices partially as the result of short honey crops (fig. 14). Since 1925 relative retail prices of extracted honey have followed relative retail food prices.

Producers' and Retall Prices of Extracted Honey, United States, 1923-1932

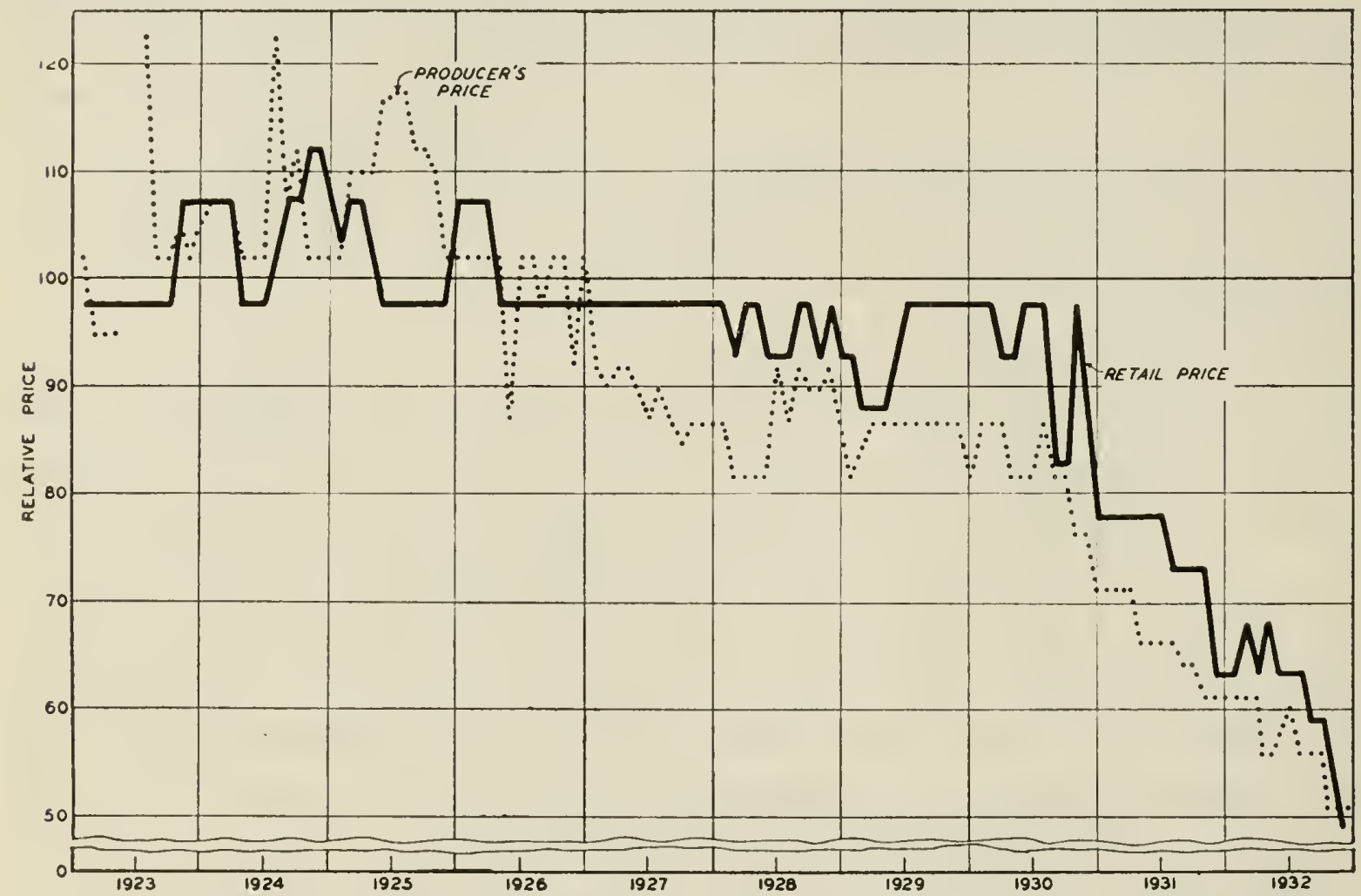

Fig. 13.-Retail prices have lagged behind producers' prices. The relatively high producers' prices of 1925 were not reflected in retail prices until the latter part of that year and the first few months of 1926. The downward trend in producers' prices beginning in 1926 was not clearly reflected in retail prices until 1928. Since the latter part of 1930 retail prices have declined precipitously. (Data compiled by authors from series of producers' and retail prices in Gleanings in Bee Culture, monthly issues. Producers of extracted honey in every section of the United States report prices for large lots, without reference to floral source, color, etc., to the aforementioned publication. Retail prices to consumers are similarly reported for extracted honey in 5-pound pails and comb honey, Fancy and No. 1. The prices indicated are average [median] prices and have been checked for their representativeness of the country as a whole.)

Retail prices of comb honey (fig. 15) have not shown the same comparative freedom from short-time fluctuations as have those of extracted honey. There has been a downward drift in the retail prices of this product since 1926, steadying somewhat during the period 1928-1930 at a level substantially below that for 1924-1926. Comparing relative retail comb-honey prices with those for the extracted product (taking the price of each in 1926 as equaling 100), comb-honey prices are found to have ranged considerably below the figures for extracted honey until 1931 when the decline in extracted-honey prices at retail was more rapid than the drop in those for comb honey (fig. 15). 
In comparison with the general retail food prices those for comb honey were relatively lower from 1927 until early in 1931 if 1926 is used as a base year $(1926=100)$. In 1931 and 1932 prices of all foods declined more rapidly than those of comb honey with the result that the relative prices of all foods and comb honey were the same.

Relative Retall Prices of All articles of Food and Relative Retail Prices of Extracted Honey, United States, 1923-1932

(Average prices in $1926=100$ )

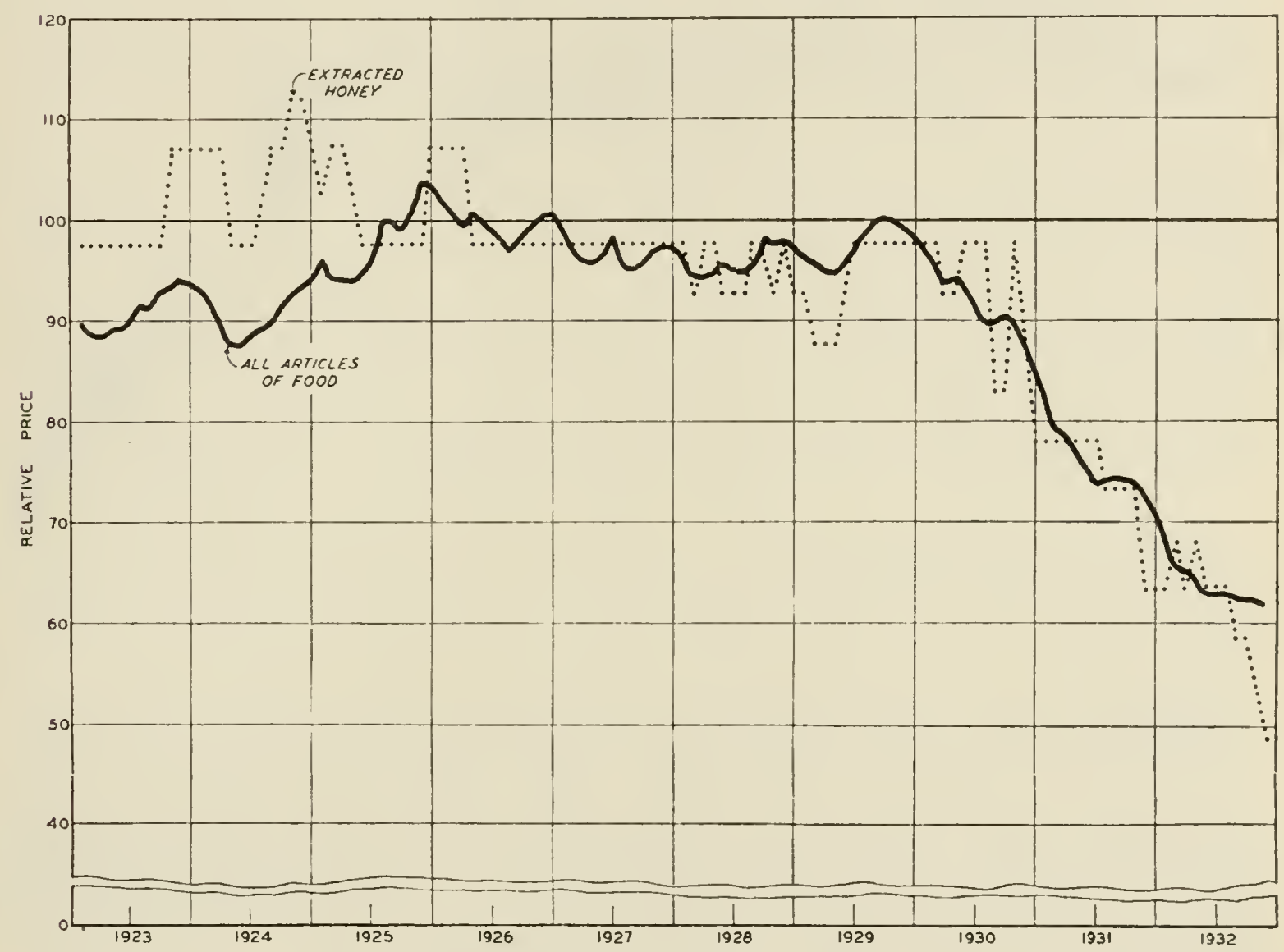

Fig. 14.- Since 1926 the relative retail prices of all articles of food and extracted honey have shown rather remarkable uniformity. During 1924 and 1925 honey prices in general were relatively high, and this was reflected in higher retail prices. (Data based upon figure 13, and U. S. Dept. Labor. Retail prices, monthly issues.)

Factors Infuencing Prices of California Honey.-A complete analysis of economic forces determining the prices of California honeys would be infinitely complex. Only some of the conditions controlling the supply of, and the demand for, California honeys can be mentioned.

Supplies of honey and the immediate prospective supplies exert an influence on honey prices that is difficult to evaluate because of the lack of data on production. The California honey crop of 1922 is estimated to have been relatively large. A similar situation prevailed with reference to the United States' crop. The effect upon producer's' prices in Cali- 
fornia (table 16) is readily discernible. ${ }^{34}$ The 1923 honey crop, in both the state and nation, was relatively small and prices increased. California crops continued to be small in 1924 and 1925, and as a result,

Relative Retall Prices of Extracted and Conb Honey, United States, 1923-1932

(Average prices in $1926=100$ )

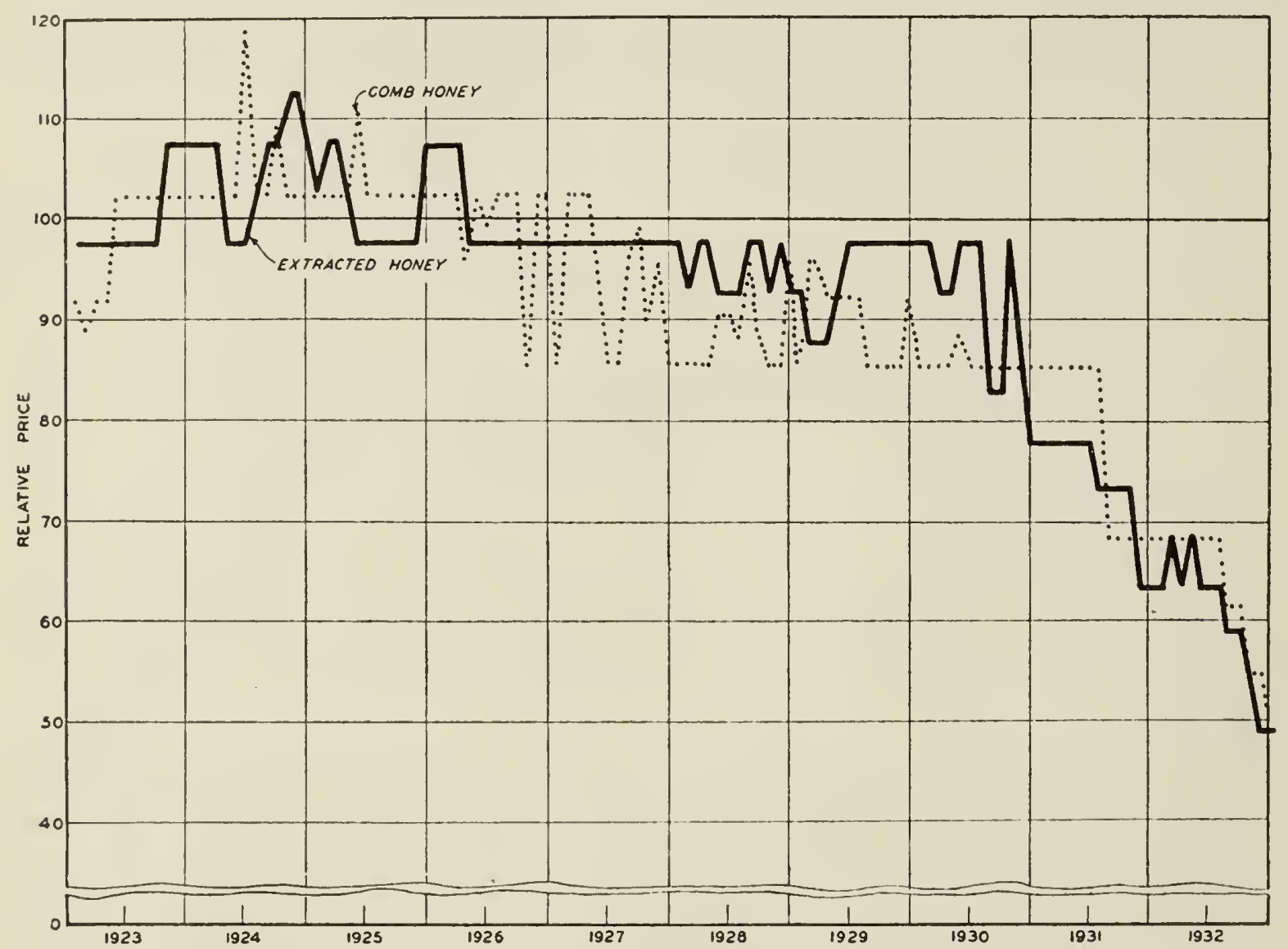

Fig. 15.-The retail prices of comb honey apparently fluctuate more than those of extracted honey. This might be expected on account of the more limited supplies of the former product and the seasonality of production. Since 1925 there has been a greater falling-off in the price of comb as compared with extracted honey. When compared with pre-war prices the meager evidence at hand indicates that the situation was reversed. (Data from figure 13.)

prices for California table honeys during these latter years were at relatively high levels.

Comb-honey supplies have been smaller during the five years 19281932 than they were during the previous two decades. ${ }^{35}$ Since a continuous price series for comb honey is not available, an examination of producers' prices in the United States shows that the decline from 1930 to 1932 was less than that for extracted honey. Wholesale comb-honey

34 The effect of the large erop was felt in the New York market. Sec: United States Department of $\Lambda$ griculture. Honey: monthly average price in producing socetions and at consuming markets, 1921-1930. U. S. Dept. Agr. Yearbook 1931: 896. 1931. Prices given in the yearlook represent sales by original receivers to bottlors, confoctioners, bakers, and jobhers.

35. Based upon information obtained by authors from manufacturers of combhoury sections. 
prices at New York reveal a similar situation. There are additional reasons for the relatively high wholesale price of comb honey in New York. Little or no comb honey comes to New York from foreign countries. Relatively high freight rates from western states, with the difficulty of transporting a fragile commodity long distances, act as a curb) on shipments.

While extracted honey is not a perishable product (honey changes in fiavor and especially in color after a period of time) the arrival of the new crop on the market appears to have an influence on price (page 49). Calculations on wholesale prices quoted by the United States Department of Agriculture on California white orange honey give evidence of a somewhat regular though slight seasonal variation. Higher prices usually prevail during the five months November to March, inclusive, while they are apparently lower from May to September, inclusive. During the eleven-year period, 1921-1931, prices in May have been lower than those in March for nine of the years. During the three months March, April, and May a slight break in price usually occurs. On the other hand, there is a tendency for these prices to rise during the three months September, October, and November.

If complete data were available for analysis, it would probably be found that the general price level exerted a dominating influence on California honey prices from 1929 to 1932. General business conditions also influence the price of honey. Orange-honey prices to producers dropped to a relatively low level during the three years of depressed business conditions-1930, 1931, and 1932. From this behavior, orange honey - at least the higher grades-would be placed in the category of Juxury foodstuffs-prices being relatively high (as compared with general prices) during periods of prosperity and relatively low during periods of unemployment and depression. Rasmussen ${ }^{36}$ states that consumers have the impression that table honey is a luxury. When incomes are reduced, people first forego the purchase of what they consider to be luxuries.

Many foodstuffs are keenly competitive. The capacity of the human stomach is limited, and the more sugar, maple sirup, molasses, or preserves are consumed the less honey will be utilized. It is likely that sweet foods are especially competitive. Honey has been and is at times used in place of sugar. The demand for these competitive products expressed through the prices paid for them exert an influence on honey prices. Various grades of honey are also in competition with each other, e.g., sage and orange, orange and alfalfa, etc.

\footnotetext{
36 Rasmussen, M. P. Some facts concerning the production and marketing of honey. New York Agr. Col. (Cornell) Ext. Bul. 221:100. 1932.
} 
A comparison between different price series, both actual and relative (table 16) shows clearly that each grade of honey has a separate and distinct series of prices. The various table honeys (extracted) unquestionably give evidence of closer correlation, one with the other, in price changes than do the table honeys as a group with those used in manufacturing, e.g., changes in the prices of orange honey have more of an effect on those of sage honey than do the changes in the prices of alfalfa honey.

Producers' Prices for Orange and Alfalfa Honey and Wholesale Prices of Cane Sugar, California, 1910-1932

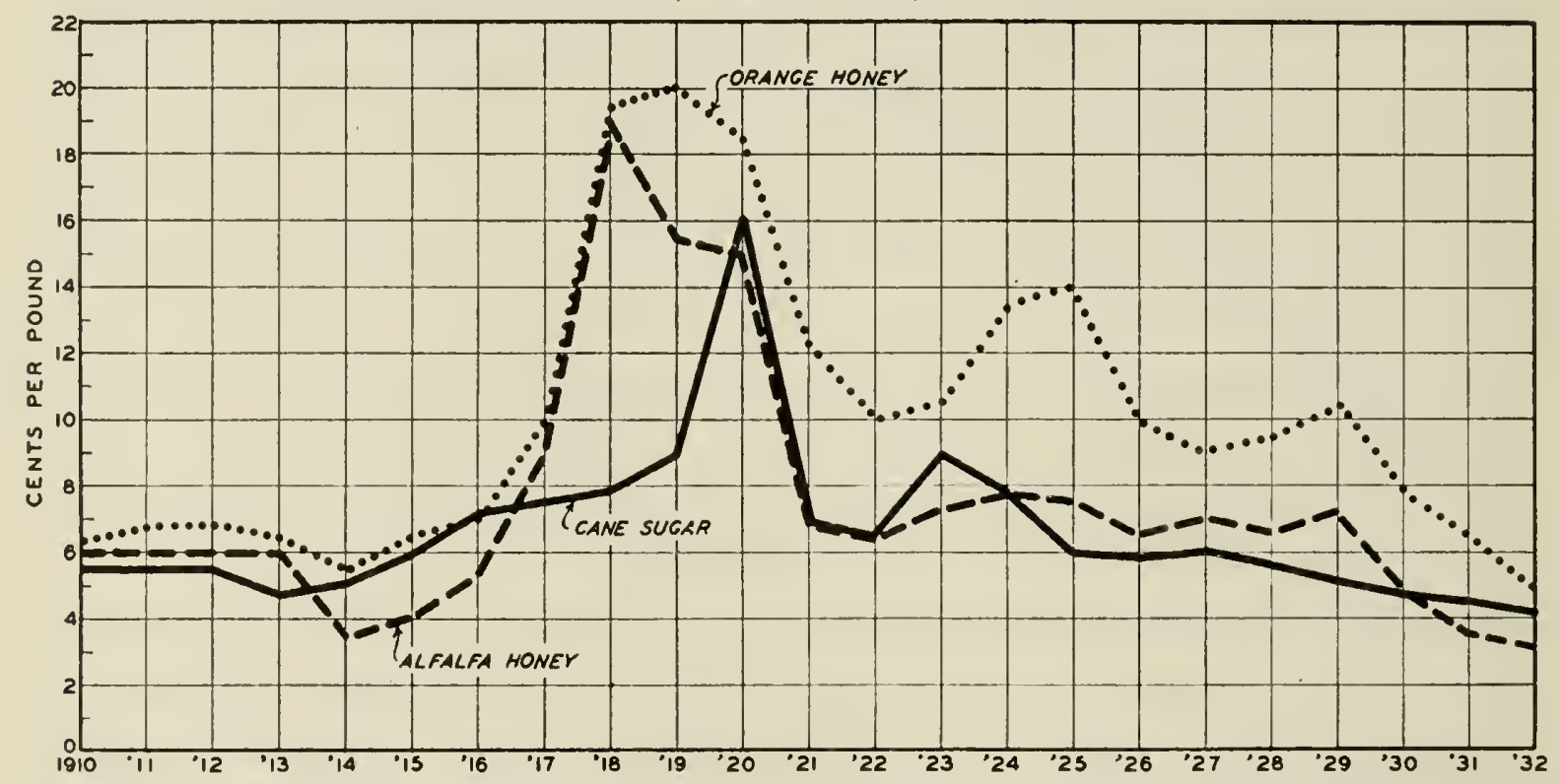

Fig. 16.-Honey prices rose to an abnormally high level during 1918 and 1919, owing partly to the artificial restrictions on the use of sugar. Since 1925 both orange and alfalfa honey, as well as other honeys, have been declining in price. The price of alfalfa honey follows that of sugar more elosely than does orange or other relatively high-priced honeys. (Data from table 16.)

Many beekeepers and students of the industry hold the opinion that low-priced sugar has been responsible for the relatively low prices prevailing for extracted honey during 1930, 1931, and 1932. It would appear that those honeys used in manufacturing are more influenced by low sugar prices than are table honeys. The relatively low price of sugar discourages the use of honey for commereial purposes when the item of cost of raw materials is an important factor. A comparison between wholesale honey and sugar prices in Cahifornia (fig. 16) clearly shows the influence which sugar prices have on honey prices, especially on those of alfalfa origin. During the World War years alfalfa-honey prices in California rose higher relatively than those of honey from any other floral source for which data are available (table 16). 'This came about, in part, on account of the substitution of alfalfa honey for sugar. Governmental restrictions on the use of sugar, however, prevented the influence of demand on the price of sugar from operating; hence com- 
parisons for this period might lead to erroneous conclusions. When the restrictions on sugar were removed and the normal forces of demand and supply began to operate, sugar prices dropped precipitously to low levels. At the same time, alfalfa-honey prices gave evidence of a similar drop. The rise in the honey price in 1923 (table 16) was undoubtedly influenced in no small degree by a rise in sugar prices, the increase in the price of alfalfa honey being proportionately greater than that of the other honeys studied. During 1924, alfalfa-honey prices again advanced owing, partly at least, to the continued relatively high price of sugar and partly to the rise in the prices of other honeys. In common with the lowerpriced alfalfa honey, light-amber sage honey has experienced a greater decline in price from the war-time peak than the strictly table honeys such as orange or white sage.

Rasmussen in honey-marketing studies ${ }^{37}$ reports corn sirup, maple sirup, and cane sugar to be competitors of honey. Prices of corn sugar, invert sugar sirup, and perhaps other sweets also have an influence on honey prices. Such sweets as invert sugar sirup and cane sugar naturally follow sugar prices. Calculations of corn sugar and corn-sirup prices over a series of years show that they have been lower than honey prices, and have been substituted for honey ${ }^{38}$ in manufacturing processes.

Series of prices on products such as preserves, spreads such as butter, margarine, etc., offer little to support many of the opinions expressed on the importance of the competition offered by these products to honey. From the standpoint of the consumer, honey has some valuable properties not possessed by other saccharine materials used as a substitute for it.

The absence of accurate information and a lack of organized, orderly marketing profoundly influence honey prices. ${ }^{39}$ An examination of the range of prices received by individuals clearly shows, that, as a whole, individual beekeepers are in too weak a position to bargain effectively.

3i Rasmussen, M. P. Some facts concerning the production and marketing of New York State honey during 1926. Farm Econ. 3:868-872. 1928.

Rasmussen, M. P. Some facts concerning the production and marketing of honey in Elmira, N. Y., 1926. Farm Econ. 3:900-903. 1928.

Rasmussen, M. P. The Chicago metropolitan district as a retail honey market. Farm Econ. 3:963-968. 1928.

38 Certain restrictions on the use of corn sugar were set aside by the Secretary of Agriculture of the United States on December 26, 1930.

39 See Voorhies, Edwin C., Frank E. Todd, and J. K. Galbraith. Honey marketing in California. California Agr. Exp. Sta. Bul. 554:1-31. 1933. 


\section{DOMESTIC TRADE IN HONEY}

Intrastate Shipments.-The larger part of the honey produced in California is consumed within the state's borders. Data now available on receipts of honey at Los Angeles and in the San Francisco Bay area, the two important centers of consumption within the state, are not wholly conclusive with reference to seasonal shipments, but it appears that orange honey arrives in largest quantities in the four months beginning with April. Shipments of alfalfa honey are largest during the five months beginning with August, and star-thistle honey shipments are apparently heaviest during the fall months. For the years reported sage and wild buckwheat-honey shipments do not give evidence of any seasonality in movement.

By means of a questionnaire, producers in various sections of the state were asked the months during which they marketed their honey. Their replies are recorded in table 17 . Some 30 reported that they marketed their product during every month of the year. There are strong indications from these returns that the majority of California producers generally market their crops during the four months beginning with August. Table 17 indicates that the low point of marketing activity is in March and April with activity getting under way in May and June.

Shipments from California.-Considerable quantities of California honey are shipped annually to the eastern seaboard, and cities in eastern United States constitute an important outlet for the California product. Satisfactory data on the extent and trend of these shipments are, however, almost completely lacking. ${ }^{40}$

New York ranks first as an eastern outlet for California honey; in fact, 94 per cent of the reported boat shipments of extracted honey to the east coast in 1931 were consigned to this port. While a considerable part was reshipped to other eastern eities or exported, New York is unquestionably the most important eastern market.

Boston, Philadelphia, New Orleans, and Baltimore receive small shipments directly from Los Angeles, but the volume of these shipments is comparatively small. Hawaii received 35,916 and 30,614 pounds of honey during 1930 and 1931 respectively from Los Angeles and San Francisco.

40 The Federal-State Market News Service (Honey and Beeswax. Receipt and Shipment Summary. 16 p. April 5, 1932. [Mimeo.]) reported intercoastal shipments of honey from Los $A$ ngeles and San Franciseo in 1931 to be 1,844,400 pounds and in 1932 to be 5,240,520 pounds. Exports in 1931 were 2,385,000 pounds, making a total of $4,229,400$ pounds of honey sent out of the state in that year. In 1932 $1,480,447$ pounds were exported, making a total of $6,720,520$ pounds sent out of the state. These figures, it is to be noted, include honey from the intermountain and Arizona districts as well as from Califormia. 
Shipments Into California.-Los Angeles and San Francisco are the normal outlets for large amounts of honey produced in the Arizona and intermountain districts and in Hawaii. Some of these honeys are consumed in the state, while others are exported or shipped to the east coast.

The largest amounts of extracted honey coming into the state originate in Arizona. The bulk of this is alfalfa honey, with that from mesquite

TABLE 17

Months of the Year in Which California Producers Sell Honey*

\begin{tabular}{|c|c|c|c|c|c|c|c|c|}
\hline \multirow{2}{*}{ Month } & \multicolumn{3}{|c|}{ South coast and chaparral } & \multicolumn{2}{|c|}{$\begin{array}{l}\text { Sacramento- } \\
\text { San Joaquin }\end{array}$} & \multirow{2}{*}{$\begin{array}{l}\text { Trans- } \\
\text { mountain } \\
\text { belt, III }\end{array}$} & \multirow{2}{*}{$\begin{array}{l}\text { Bay } \\
\text { region } \\
\text { and } \\
\text { cut-over } \\
\text { redwood } \\
\text { area, } \\
\text { belt IV }\end{array}$} & \multirow{2}{*}{ Total } \\
\hline & Belt Ia & Belt I $b$ & Belt Ic & Belt II $a$ & Belt II $b$ & & & \\
\hline January ...................... & 11 & 6 & 1 & 3 & 5 & ... & 1 & 27 \\
\hline February ..................... & 10 & 4 & $\ldots$. & 3 & 8 & $\ldots$. & 1 & 26 \\
\hline March & 5 & 4 & $\ldots$. & 3 & 7 & $\ldots$ & 1 & 20 \\
\hline 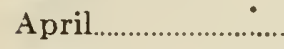 & 2 & 2 & $\ldots$. & 4 & 5 & 1 & 1 & 15 \\
\hline May................................ & 9 & 3 & .... & 4 & 3 & 1 & 1 & 21 \\
\hline June $\ldots \ldots \ldots \ldots \ldots \ldots \ldots \ldots$ & 17 & 3 & $\ldots$. & 10 & 3 & 2 & 1 & 36 \\
\hline July & 17 & 9 & 2 & 8 & 5 & 4 & $\ldots$. & 45 \\
\hline 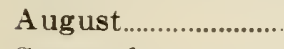 & 21 & 16 & 3 & 11 & 10 & 5 & 1 & 67 \\
\hline September.................. & 28 & 20 & 1 & 19 & 21 & 8 & 2 & 99 \\
\hline October & 25 & 15 & 1 & 21 & 19 & 8 & 2 & 91 \\
\hline November...................... & 21 & 12 & 2 & 15 & 14 & 6 & 2 & 72 \\
\hline 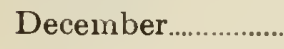 & 17 & 9 & 3 & 8 & 7 & 1 & 1 & 46 \\
\hline & - & 一 & 一 & 一 & - & 一 & 一 & - \\
\hline $\begin{array}{l}\text { Total producers } \\
\text { reporting }\end{array}$ & 50 & 35 & 4 & 32 & 27 & 13 & 3 & 164 \\
\hline $\begin{array}{c}\text { Producers mar- } \\
\text { keting honey } \\
\text { during every } \\
\text { month................... }\end{array}$ & 16 & 8 & 1 & 3 & 2 & $\ldots$ & 1 & 31 \\
\hline
\end{tabular}

* In compiling returns those marketing honey during all months of the year were listed separately, while those disposing of honey at retail were omitted. In the computations each month counted as 1 , e.g. a producer stating that he marketed his crop in August, September, and October would add 1 to each of these months.

Source of data: state.

Computations by authors upon the basis of returns from questionnaire sent to beekeepers of the

occupying a minor place. Idaho and Utah ranked second and third, respectively, in shipments in 1931 and 1932, honey from these states being largely alfalfa and sweet clover. Hawaii ranks with Arizona in shipping honey to California.

The bulk of the honey coming to California from other states in 1931 and 1932 entered in the four months beginning with September. Hawaiian honey during these years appeared in largest offerings in the six months beginning with October. Sizable amounts of honey in glass were sent from New York in both 1931 and 1932. Some of this honey 
evidently came from abroad, since imported honey was found in studies conducted by the authors. ${ }^{41}$

Shipments of comb honey to Los Angeles and San Francisco were heavy during the five months beginning with September in 1931 and 1932. The peak shipments were made in November, and they decreased rapidly in January and December. Idaho, Nevada, and Colorado contributed the bulk of the shipments for the two years studied.

\section{UNITED STATES EXPORT TRADE IN HONEY}

While the United States as a whole produces honey ${ }^{42}$ in excess of domestic consumption, exports of this commodity are of comparatively recent development. As early as 1867 small shipments were sent to foreign markets, but it was only with the stimulation of war-time production activity and demand for sweets and energy foods that these exports reached significant volume. Beginning in 1916 shipments abroad, largely to the United Kingdom, began to expand rapidly. They reached a total of $11 \frac{1}{2}$ million pounds in $1918^{43}$ and were in excess of 9 million pounds in 1919.

In 1920 and 1921 the post-war depression brought a great decline in exports, but following this period they steadily recovered until, in 1927 , a total of more than 12 million pounds was reached. Germany was at this time by far the most. important customer with the United Kingdom ranking second. There has again been a decided slump (fig. 17) with exports for 1930, 1931, and 1932 in the neighborhood of 4 million pounds.

Importance of California Exports.-From 50 to 75 per cent of all honey exported from the United States ordinarily passes through the customs districts of San Francisco and Los Angeles, the latter usually being the most important honey-exporting center in the Union. Total exports from California ports have varied in recent years from in excess of 9 million pounds in 1927 to about $21 / 2$ million pounds in 1930 and 1931,

41 Voorhies, Edwin C., Frank E. 'Todd, and J. K. Galbraith. Honey marketing in California. California Agr. Exp. Sta. Bul. 554:1-31. 1933.

42 Reference to honey as used throughout this section on export trade is to extracted honey unless otherwise specified.

43 Figures for exports of honey from the United States and imports by Germany and the United Kingdom in this section are from the following sourees:

United States exports: U. S. Dept. Com. Foreign Commerce and Navigation of the United States, annual issues.

California exports: Data obtained by authors from U. S. Dept. Commerce, San Francisco, California.

United Kingdom imports: 'The Trade of the United Kingdom, amnual issues.

Germany imports: Statistisches Reichsamt. Der auswärtige Handel [Statistics of the (German) Government Office. The foreign trade]. Annual and monthly issues. 
and $1 \frac{1}{2}$ million pounds in 1932 . These totals include honey from the intermountain states and Hawaii exported through California ports although they do not include California honey that is exported from the east coast. California producers are significantly interested in healthy export conditions, since such an outlet is highly desirable, if not essen-

United States Honey Exports by Principal Countries, 1925-1932

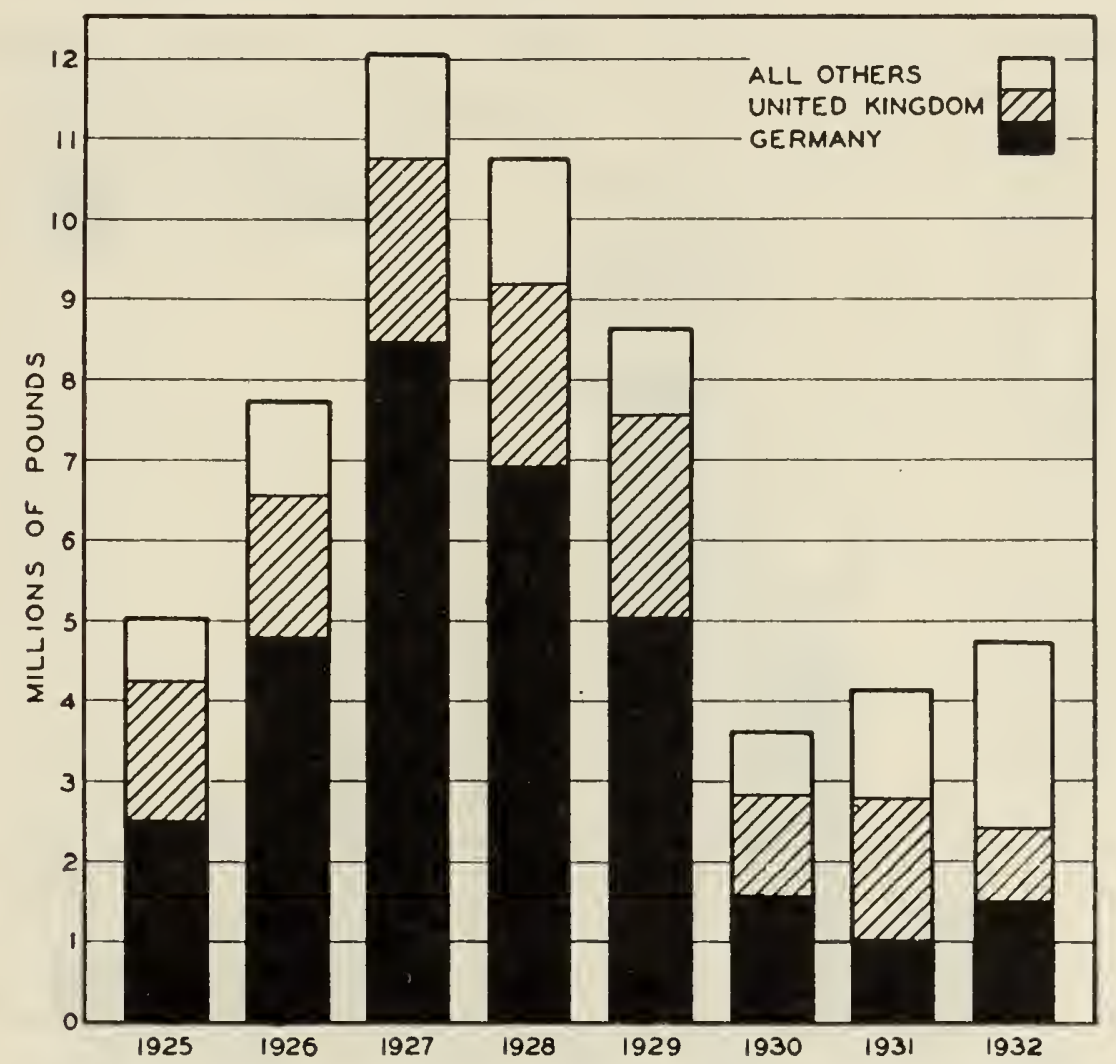

Fig. 17.-Exports of honey from the United States declined in volume from 1927 to 1930 . From the latter year to 1932 an increase occurred. Exports to Germany (shown in black) have suffered the greatest shrinkage since 1927, while exports to the United Kingdom have shown a much less pronounced decline. During 1932 Italy ranked ahead of Germany and the United Kingdom in taking United States' exports. (Source of data: see page 66, footnote 43.)

tial, for the honey which flows more or less naturally into California centers whether it be from the intermountain states, Hawaii, or from California itself.

Trend and Distribution of California Honey Exports.- The exports from California ports for the years 1925-1931 are shown in figure 18 . The total exports, while showing a downward trend in 1928 and 1929, fell sharply in 1930, 1931, and 1932. The reason for this can be largely found in the great shrinkage of exports to Germany. These, in 1931, were but 23 per cent of the 1929 total and 17 per cent of the average yearly exports for 1925-1929 inclusive. Exports to the United Kingdom in 
1931, on the other hand, were 73 per cent of the exports for 1929 and 79 per cent of the average yearly exports for the period 1925-1929.

For the years 1925-1929 exports to Germany constituted approximately 67 per cent of all the honey leaving California ports for foreign countries, while the exports to Germany and United Kingdom combined have rarely been less than 80 per cent of the total for any one year (fig. 18).

California Honey Exports by Principal Countries, 1925-1931

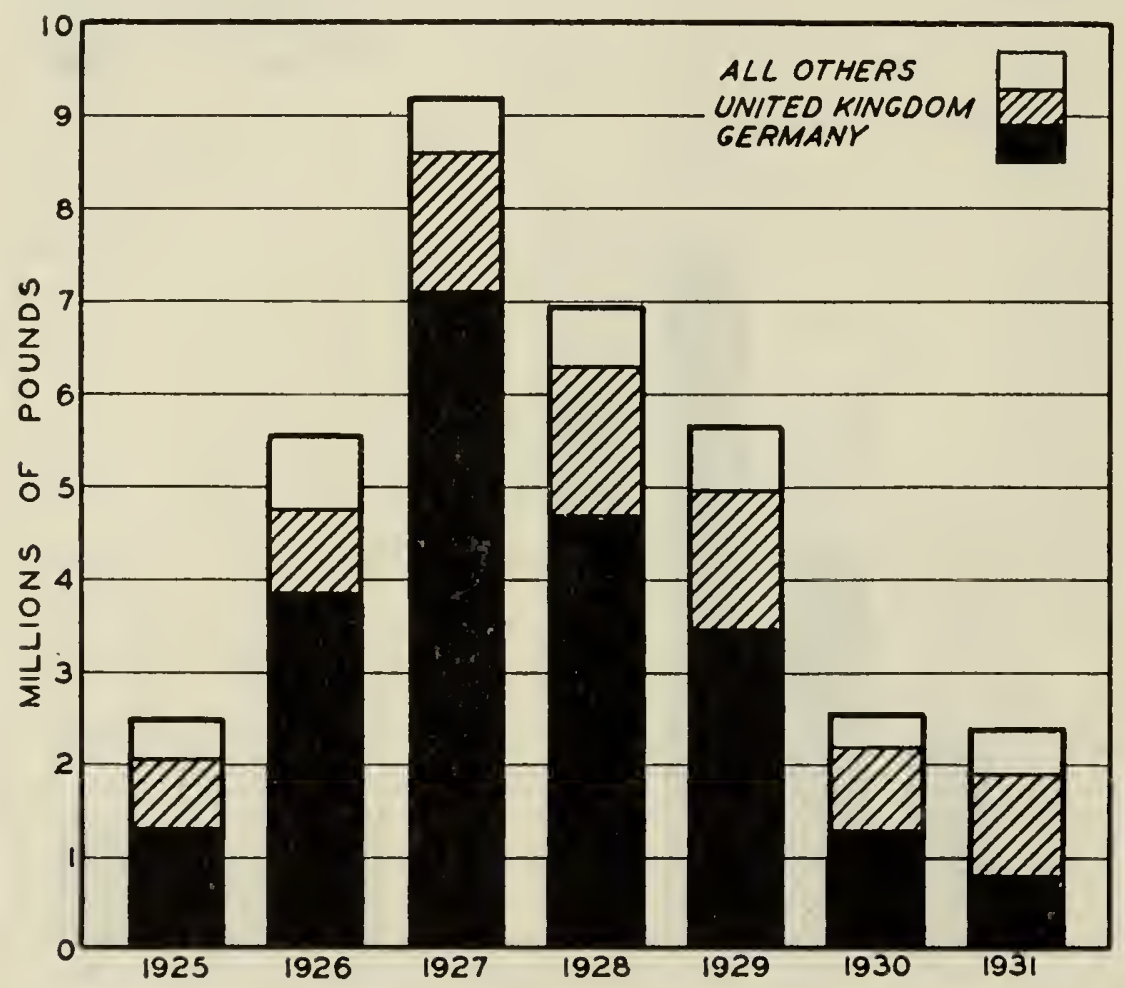

Fig. 18.-Germany and the United Kingdom are the most important foreign outlets for California honey. Exports to Germany, however, have shown a steady decline since 1927 and this has been particularly abrupt in 1930 and 1931. (Source of data: see page 66, footnote 43.)

Netherlands, Denmark, France, and Italy usually take from 5 to 10 per cent of the California exports while the remaining 10 per cent (approximately) is distributed in relatively small quantities to a large number of countries. In 1932 the percentages were Germany 29.9, United Kingdom 26.1, Italy 16.6, France 14.8, other countries 13.6. Exports to the Orient, chiefly to China and British India, are of small but constant quantity apparently for consumption by western residents.

The German Market.-From 1926 to 1929 inclusive (fig. 19), the United States was by far the most important single source of the honey imported by Germany. Since 1927, however, the proportion of Germany's total imports coming from this country have been undergoing a rather steady decline (fig. 20). In 1927 the United States furnished more than 
German Honey Imports by Countries, 1925-1931

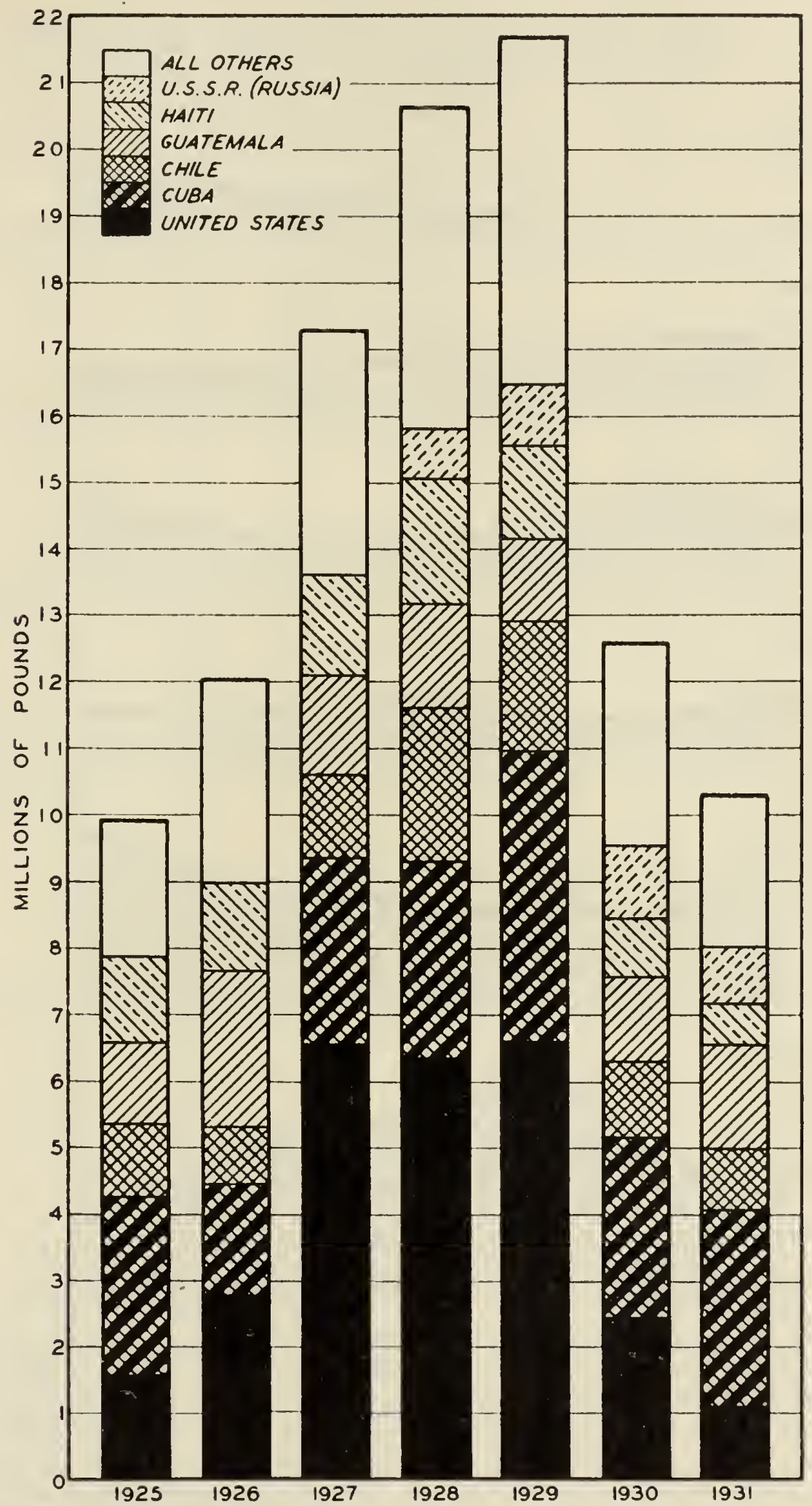

Fig. 19.-Germany is a large importer of honey and draws these imports from many countries. In 1929 the United States (shown in black) was by far the largest single source of supply, but within a period of two years German imports of United States honey have declined to an insignificant amount. (Source of data: see page 66, footnote 43.) 
one-third of the honey imported by Germany, but by 1931 this had dropped to only slightly more than one-tenth.

German Honex Imports by Countries, 1925-1931

(In per cent of total yearly imports)

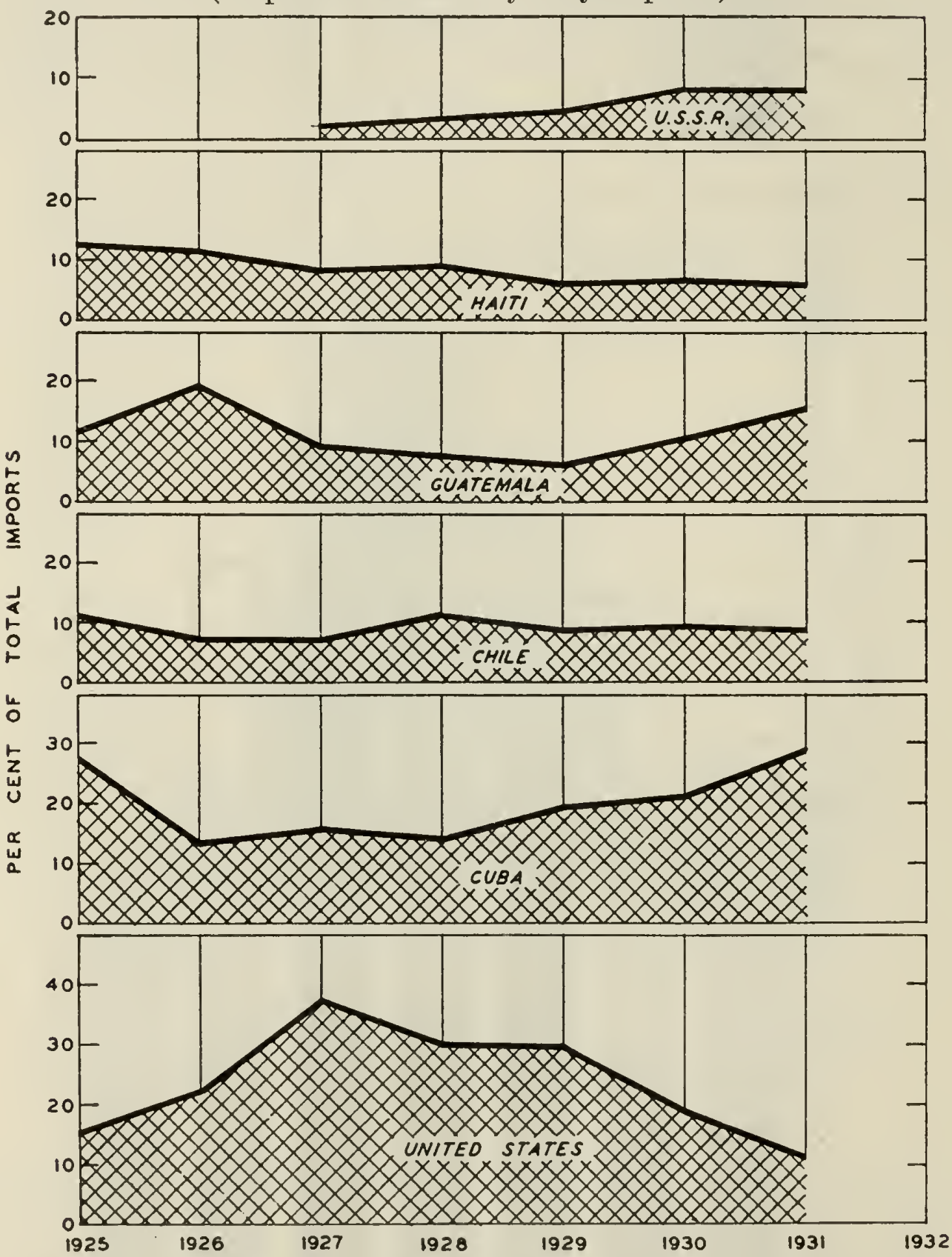

Fig. 20.-Honey imports into Germany from each of the six most important somrees are shown as the pereentage of total imports for 1925-1931. While total imports of honey by Germany declined by about half in 1930 and 1931 , as compared with 1928 and 1929 , the above diagram shows that the United States has lost ground to Cuba, Guatemala, and U. S. S. R. (Russia) in supplying such part of the German honey imports as remain. (Souree of data: see page 66 , footnote 43. )

Countries Competing in the German Market.-North, Central, and South American countries and the West Indies furnish the bulk of Germany's imports (figs. 19 and 20) of which Cuba, Chile, Guatemala, and Haiti are the most important sources of supply exclusive of the United 
States. While German imports have shrunk by about half in 1930 and 1931 and the total imports from all countries have been affected to a greater or lesser extent, this shrinkage has fallen much more heavily upon the United States, and hence, California, than upon any other one

\section{Import Value of Honey from Cuba, Chile, and Guatemala at GerMan Ports, 1925-1931}

(Expressed in per cent of the value of United States honey)

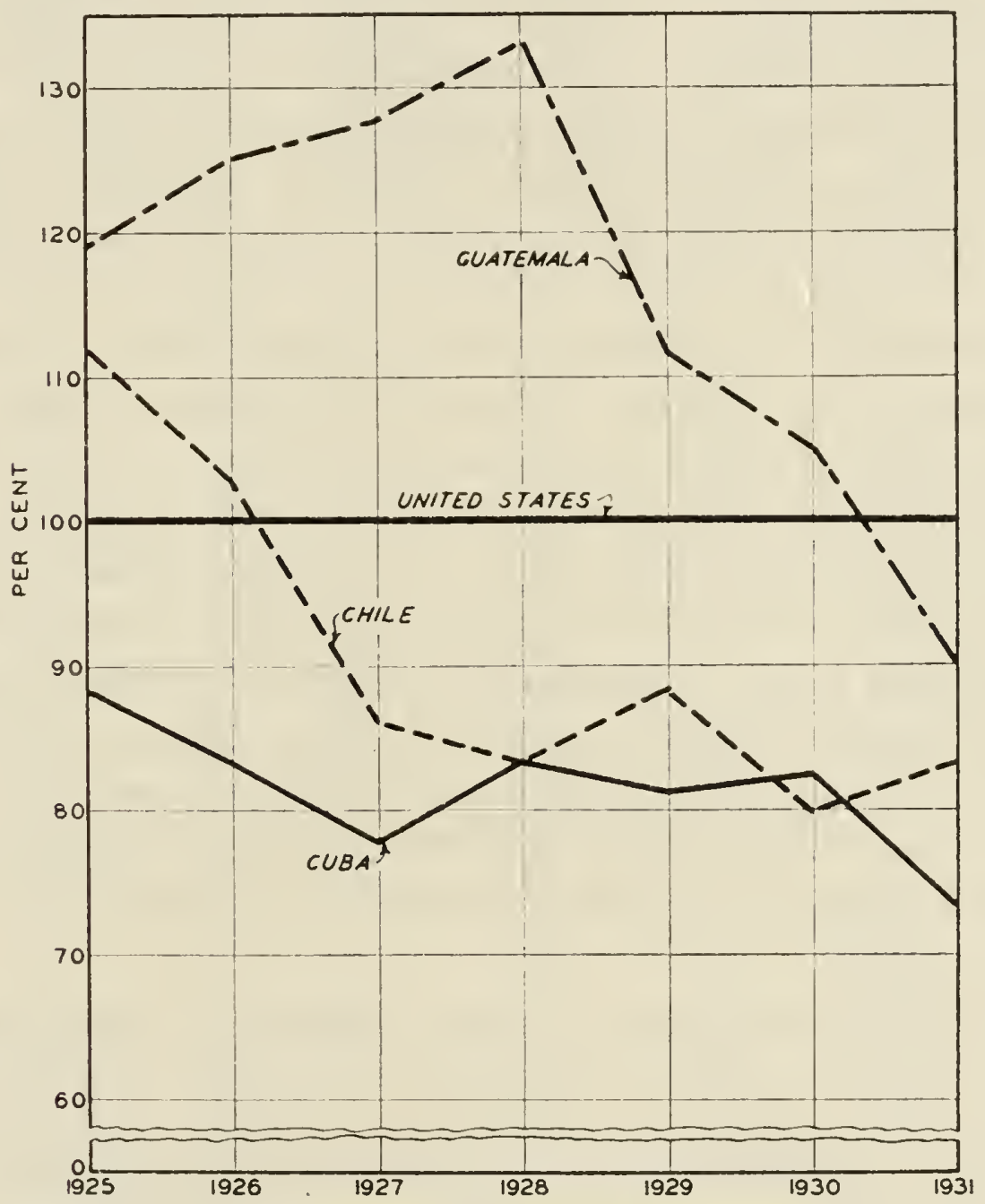

Fig. 21.-This figure shows the average yearly import value of honey (per pound) coming into German ports from the more inportant sourees of supply. In each year the average per-pound value of honey from the United States is represented as equaling 100, and hence the perpound value of honey from other countries becomes a per cent of the average value of United States honey for that year. (Source of data: see page 66 , footnote 43 .)

source. Cuba and Guatemala during this period have increased their relative share of German imports (fig. 20), while Chile and Haiti have about held their own. In 1930 and 1931 Cuba displaced the United States as the most important foreign source of supply for the German market.

Factors Affecting German Imports of United States Honey in 1930 and 1931.-It is reasonable to expect that the German imports from the 
United States would have suffered some decline in the past two years. An increase in the German tariff on honey from $4 \frac{1}{2}$ to over 7 cents a pound at the beginning of $1930^{44}$ (table 18 ), combined with disturbed economic conditions and reduced purchasing power, brought about a rapid shrinkage of total honey imports.

That the imports of United States honey should have declined both absolutely and in comparison with the imports from all other countries is not so readily explained. A report ${ }^{45}$ from the American Consulate-General at Hamburg, Germany, states that shippers in Cuba, Central America, and Chile responded quickly to the increased German honey import duties by lowering their quotations. American shippers, on the other hand, were inclined to maintain their prices at a somewhat higher point. Figure 21, showing the relative valuations of honey from competing countries as declared at German ports, indicates that in recent years United States honey has been substantially higher in price than that from competing countries. By taking the average declared value of United States honey per pound at German ports as equaling 100 for each of the years from 1925 to 1931, it is found that the valuations of honey from other countries have declined greatly as compared to those of United States honey. Guatemalan honey has dropped from about 30 per cent above the valuation of United States honey in 1928 to 10 per cent below in 1931. Chilean honey was 12 per cent above in 1925 and nearly 17 per cent below in 1931 . The Cuban product, always below that of the United States in valuation, has shown a further relative decline during this period. ${ }^{46}$

A further factor considered in some quarters to bear upon the disproportionate decline of German imports from the United States and particularly from California is the diastase ${ }^{47}$ content of some California honey. German regulations with respect to minimum diastase content of honey entered for direct domestic consumption are fairly rigorous and some California honeys have shown a deficiency in this respect. ${ }^{48}$

${ }_{44}$ On March 1, 1933, a further increase to approximately 8.6 cents a pound was put into effect.

45 Schnare, Lester I. German market for honey. American Consulate-General, Hamburg, Germany. Report No. 158.

46 Computations by the authors based on: Statistisches Reichsamt. Der auswärtige Handel [Statisties of the (German) Government Office. 'The foreign trade]. Annual issues.

47 Diastase is an enzyme which changes starches to sugars. It occurs abundantly in saliva.

48 Vansell, George H., and Stanley B. Freeborn. Preliminary report on the investigations of the source of diastase in honey. Jour. Econ. Ent. 22:922-926. 1929. Also in: Gleanings in Bee Culture 57:518. 1929.

Isathrop, R. E., and H. S. Paine. Diastatic activity of some American honeys. Indus. and lingin. Chem. 23:71. 1931. 


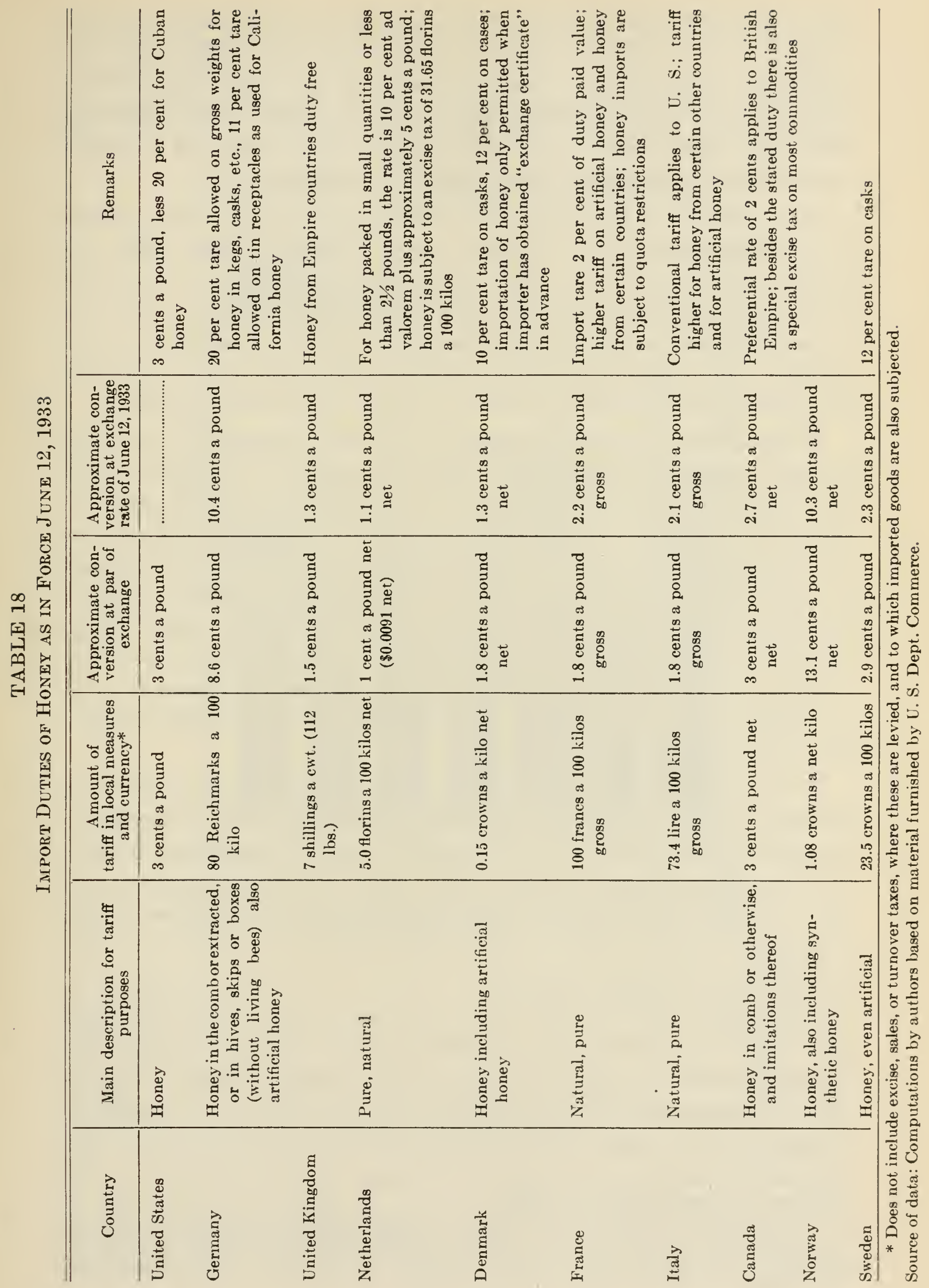


The diastase content has been used in Germany as an indicator of overheating, but it is believed that for certain honeys this brings about unwarranted discrimination. Technical research has shown that the diastase content is apparently related to the pollen content of the honey and that California orange and alfalfa honeys are naturally low in pollen count and hence in diastase whether they are heated or not.

Uses of Honey in Germany and Consumer Preference.-Honey finds its most important use in Germany as an article for direct table consumption although use in baking and candy manufacture is of considerable importance. For table use the German consumer prefers a "granulated honey that can be spread like butter." ${ }^{49}$ Liquid honey is not popular. The light-colored United States product has in the past been widely used for blending with darker honeys from other countries.

Future Status of the German Market for California Honey.-The immediate possibilities of Germany again becoming an important outlet for California honey are not hopeful. Although honey is apparently consumed more widely in Germany than in the United States, it borders on the luxury class as an article of diet, and, therefore, it will be seriously curtailed while Germany suffers from economic disorders as at present. Imports by Germany from California have tended to follow fairly closely, in recent years, the trend of general business conditions in that country. A further factor tending to make exports to Germany on a profitable basis more difficult is the heavy increase in the tariff in recent times as mentioned above (table 18).

On the other hand, it has been shown fairly conclusively in the past that the California product can compete satisfactorily for German prefcrence with the honey of any other country from the standpoint of quality. Should German purchasing power improve and the present condition of stifled international trade give way in favor of lowered tariffs or changed economic relations, then California can well expect to resume its position in the German market.

The British Market.-Over a period of years the United States has been the most important single source of the honey imported by the United Kingdom, the major portion of which has come from California ports. ${ }^{50}$ Imports of the United Kingdom have varied from 7 to 10 million pounds in recent years with the United States furnishing usually about

49 Schnare, Lester L. German market for honey. American Consulate-General, Hamburg, Germany. Report No. 158.

50 The Empire Marketing Board in an investigation of the retailing of honey in London and Glasgow states: "Nore than half of the United States honey found was simply described as Californian." [Great Britain] Empire Marketing Board. The demand for honey. F.M.B. 50. p. 50. 1932. 
2 million pounds (fig. 22). California exports have constituted from one-half to two-thirds of the latter.

Countries Competing in the British Market.-The most important competitors of the United States in the honey market of the United Kingdom are the British West Indies, New Zealand, and Canada. In

United Kingdom Honey Imports by Countries, 1925-1931

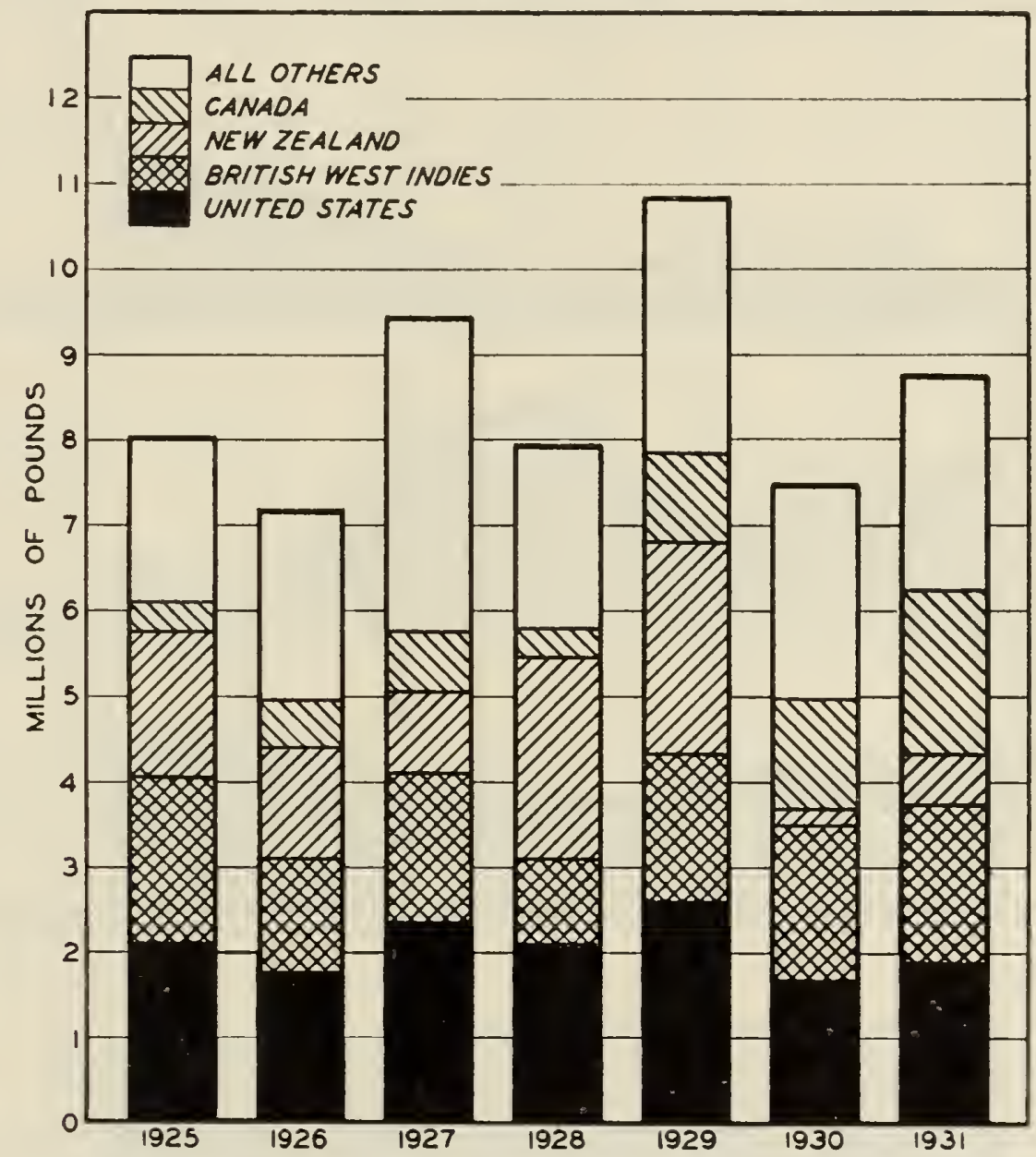

Fig. 22.-Honey imports of the United Kingdom show comparatively little variation from year to year. The United States, since 1925, has been the largest single source of supply, although occasionally surpassed by British West Indies or New Zealand and in 1931 by Canada. (Source of data: see page 66 , footnote 43. )

recent years about 65 per cent of the product coming on the British market has been distributed rather equally between the United States, the British West Indies, and New Zealand (figs. 22 and 23). Since 1925 Canada has been rapidly expanding her exports and now occupies an important place. Cuba, Chile, Union of Socialist Soviet Republics (Russia), Australia, Dominican Republic, Haiti, and other countries furnish the remaining imports of the United Kingdom. In 1931 the Union of Socialist Soviet Republics occupied fourth place among the countries, supplying the United Kingdom market with 7.6 per cent of the total imports. 
Honey from the West Indies, primarily Jamaica, while representing a considerable volume, is not considered of particularly good quality and sells at a lower price than the product from other countries. New Zealand, Australia, and Canada, however, have exercised much care in

United Kingdom Honey Inrorts by Countries, 1925-1931

(In per cent of total yearly imports)

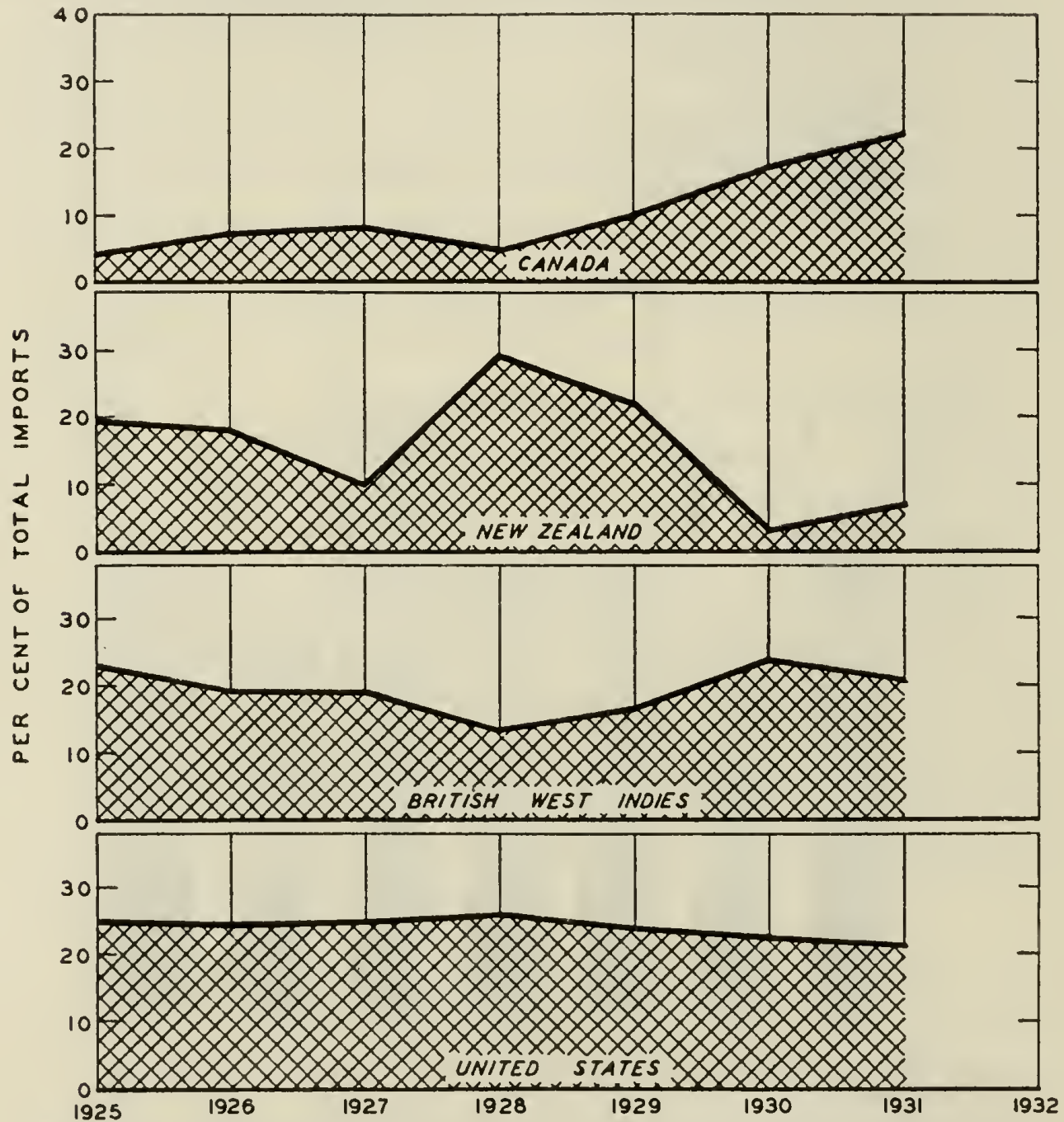

Fig. 23.-This figure shows honey imports from each of the four most important sources as the percentage of total imports for any one year. The constant proportion of the total honey imports of the United Kingdom, furnished by the United States, is a striking feature of the above diagram. The decline in imports from New Zealand in 1930 and 1931 is probably more indicative of poor crop conditions than any withdrawal from this market. (Source of data: see page 66 , footnote 43 .)

standardizing their honey and in building up a reputation for quality, and the price obtained has been in keeping therewith. New Zealand and Canada have advertised honey in the United Kingdom rather widely and seemingly with good results.

While honey from the United States showed the highest import valuation of any of the major countries sending honey to Germany, the import valuations of the United Kingdom for New Zealand and Canadian honey 
Import Value of Honey from British West Indies, New Zealand, Canada, and Chile at United Kingdom Ports, 1925-1931

(Expressed in per cent of value of United States honey)

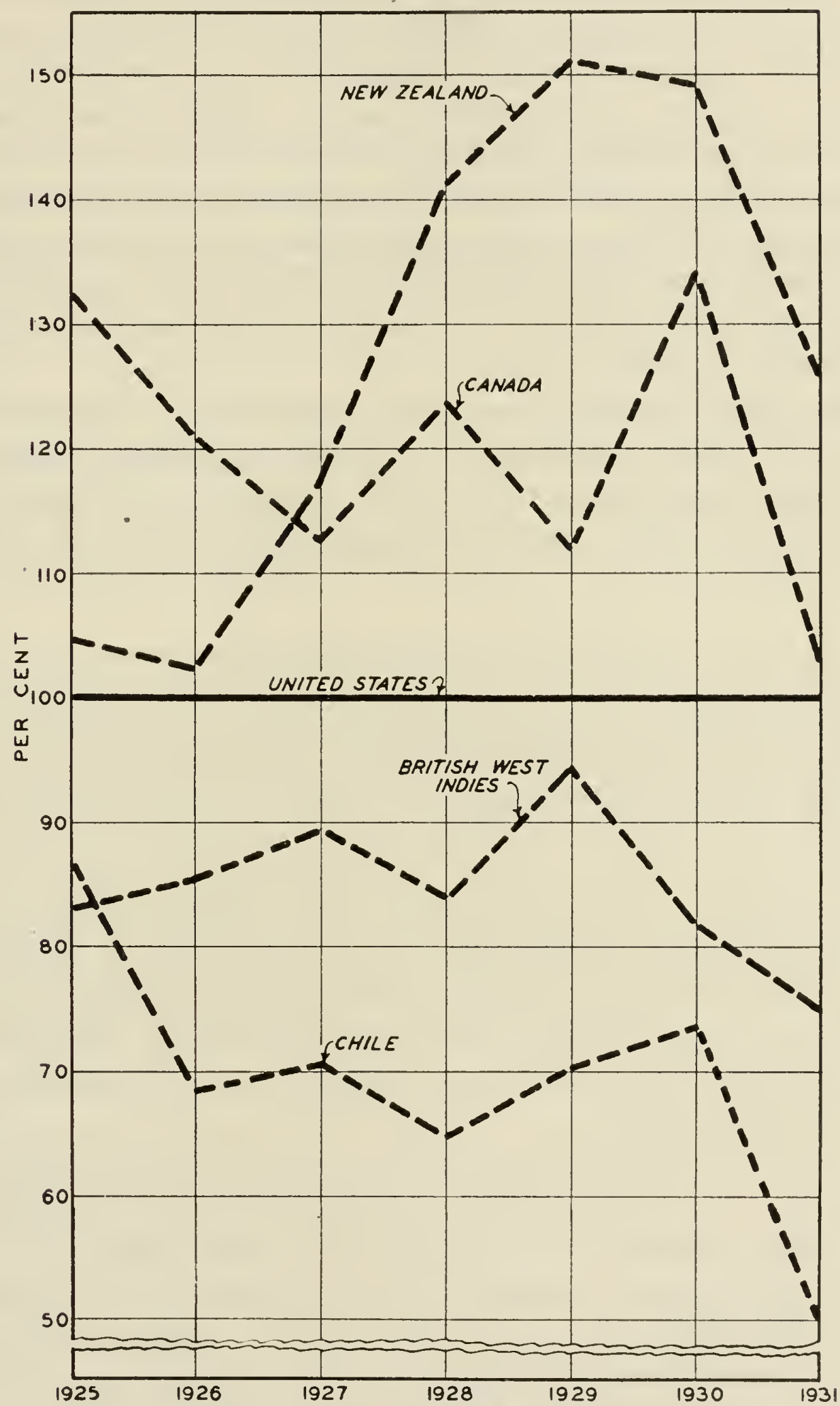

Fig. 24.-This figure shows the average yearly import value of honey (per pound) coming into United Kingdom ports from the more important sources of supply. In each year the average per-pound value of honey from the United States is represented as equaling 100, and hence the per-pound value of honey from other countries becomes a per cent of the average value of United States honey for that year. (Source of data: see page 66, footnote 43.) 
are much above the valuation of honey from the United States (fig. 24). In 1930 Canadian honey was valued at 35 per cent above the honey from the United States while that from New Zealand was valued at nearly 50 per cent above. This situation was not so marked in 1931, when the New Zealand product was 25 per cent above United States honey and the comparatively large shipments of Canadian honey only about 3 per cent above. This in all probability does not indicate with precise accuracy the relative selling price per pound, but it does serve to show that United States, and hence California, honey is far from being undersold in this market by the most important competitors with the exception of perhaps the British West Indies and Chile. The higher valuation of the California product in the latter case probably expresses approximately the difference in quality.

Use of Honey in the United Kingdom and Consumer Preference.-The use of honey in the United Kingdom is somewhat similar to that in the United States. Table use is of primary importance with small outlets in baked goods, candy, and for medicinal preparations. 'The following statement has been made in reference to consumer requirements :

Light-coloured extracted honey sells more readily than dark-coloured although in the north of England dark honey sells more readily than in the south ... In general clear [extracted, not granulated] honey and set [extracted, granulated] honey are in about equal demand. A set honey of about the consistency of cream is generally preferred to solid, coarsely set honey ... it is a matter of common cbservation that retail sales of honey are greatest during the winter months.51

F'uture Status of the British Market for California Honey.-Eco. nomic conditions during 1930-1932 were as unfavorable in England as in Germany, although there is reason to believe that the demand for honey has been much more constant in the United Kingdom. That future imports will depend in an important measure on the prosperity of the country is undeniable.

Two further factors which make exports to the United Kingdom in the near future a matter of uncertainty are Imperial preferences and unstable foreign exchanges. The launching of a preferential tariff policy by the United Kingdom (see table 18) places California's three most important competitors-New Zealand, British West Indies, and Canadaat a distinct advantage. Such developments as take place in the next few years with respect to British Empire trade preferences will be a very important factor in determining the amount of California honey which

51 [Great Britain] Ministry of Agriculture and Fisheries. Report on the marketing of honey and beeswax in England and Wales. Economic Series 28. p. 18-19. 1931. 
will go on the British market and the profitableness of exports from California ports.

The unstable condition which characterizes world currencies (1933) reacts unfavorably upon all forms of export trade, and while it is not expected that this condition will prevail indefinitely, it will materially darken the outlook for foreign markets until satisfactory measures for stabilization are effected.

From the consumer standpoint the quality of California honey is well regarded in the United Kingdom, although the New Zealand, Canadian, and Australian products are far from inferior in this respect and have the distinct advantage of centralized control and active trade promotion. To meet this competition in the future, it will be necessary that California honey be carefully kept to standard and merchandised abroad in a progressive way. Without any central organization for such purpose, it would appear exceedingly difficult for California producers to expect material progress in this connection, or, consequently, any important expansion of the British market as an outlet for California honey.

\section{THE WORLD HONEY SITUATION}

There are few agricultural industries that are as widely distributed over the land surface of the earth as bee culture and honey production. The honeybee apparently knows but few geographical or climatic limitations, and nectar-producing plants of greater or lesser importance have an equally wide distribution. On the North American continent honey production of commercial importance is found surviving the rigorous winters of the prairie provinces of Canada and carrying southward well into the tropical regions of Central America. Similarly the areas of heavy rainfall in the West Indies and the arid sections of Arizona support important production. This adaptability, the fact that the pollinizing activities of the honeybee are essential or desirable for the fertilization of many commercial plants, and perhaps other factors, have carried the production of honey into almost every important country of the world. The economy of world honey production is, therefore, not one wherein specialized areas supply other areas which do not or cannot produce honey, but rather of areas with a more or less incidental surplus sending this to sections where consumption of honey is in excess of domestic production. Few, if any, countries in the world look upon their honey exports as being of primary importance.

To the California honey producer a world view is of the utmost importance in light of the large exports originating in the state. Increasing 
or decreasing production, failure of crops, or above-normal supplies in other areas have a decided effect upon exports from the United States and hence upon domestic prices.

In general, the surplus honey-producing regions of the world are North America, parts of South America, the Caribbean area, New Zealand, Australia, and, to some extent, the Union of Socialist Soviet Republics. Statistical information on trends of production or general development of the industry is scarce especially for the Latin American countries, although certain of these loom fairly important in the world honey trade. The following countries, exclusive of the United States, grouped roughly according to geographical location, contribute the major portion of the honey entering the world's channels of commerce: Cuba, British West Indies, Haiti, Dominican Republic, Guatemala, Mexico, Canada, Chile, Argentina, New Zealand, and Union of Socialist Soviet Republics.

The climate and flora of $C u b a$ are exceedingly well suited to the production of honey, and this island has come to rival the United States as a leading exporter. Cuban honey, however, does not rank particularly high on the German or British markets from the standpoint of quality, and it usually sells for considerably less than the products from California, Guatemala, or the British Dominions. There is some evidence that the lower quality is the result of lax standards for exported honey and the method of packing in barrels and casks for shipment abroad.

The German tariff of 1930 and the subsequent partial collapse of the German honey market have reacted severely upon the Cuban industry, and unless conditions materially change, little incentive for further increases in production may be expected.

Honey originating in the British West Indies is chiefly produced in Jamaica. This island is said to have the highest production to the square mile of any country in the world. ${ }^{52}$ Production methods are well advanced, and the most important source of nectar, the logwood tree, yields a very desirable product.

Jamaican honey has met with adverse discrimination ${ }^{53}$ in the British market for many years as the result of poor standardization and the method of packing for export in casks that are in some instances reputedly secondhand and poorly cleaned. This situation is, however, well

52 Produce Markets Review. Honey production in Jamaica. London, England. Tuly 17, 1926. Quoted in: U. S. Dept. Agr. Bur. Agr. Econ. Honey No. 200. Market News Service, semimonthly report. Washington, D. C. Sept. 15, 1926. (Mimeo.)

53 [Great Britain] Imperial Economic Committee. Report of Imperial Economic Committee on marketing and preparing for market of foodstuffs produced within the Empire. Seventh report-Honey. London. H. M. Stat. Off. p. 69. 1928. 
recognized and attention is being given to every possible means of improvement.

Haiti and the Dominican Republic export considerable quantities of honey to Germany and somewhat smaller amounts to France and the United Kingdom. In both countries there is a good supply of nectarproducing plants. Production methods are less advanced there than in the United States although movable frame hives of a makeshift type are in general use. ${ }^{54}$ As with honey of the West Indies, generally, lack of standardization and poor packing for export have brought discrimination abroad. Second-hand casks are often used and this container, along with lack of export supervision, has in the past tended to keep honey from these countries at a disadvantage. The weakness of the situation is recognized but improvement is apparently slow.

Honey from Guatemala ${ }^{55}$ is generally recognized as being of the hest quality of any produced in the Central American area and it is highly regarded on the markets abroad. ${ }^{56}$ It would seem that this quality is protected by a better export system than that of the West Indies, althongh strict government supervision or grading is lacking. Production methods are apparently rather well advanced. The industry in Guatemala was stimulated in the period immediately following the War and at that time considerable quantities of honey were sent to the United States. Germany has since become by far the most important foreign outlet.

Limited quantities of honey from Mexico have come on the German market in recent years and small amounts are ordinarily exported to the United States. Modern methods of bee culture in Mexico are of comparatively recent development, and production is probably still carried on in a primitive way in many sections of the country. Mexican honey varies considerably in type and quality as it appears on markets abroad.

Production in Canada ${ }^{57}$ has expanded rapidly in recent years. From

54 Smith, Roger C. Bees and beekeeping in sunny Haiti. Amer. Bec. Jour. 70: 130-133, 184-185. 1930.

Maldonado, B. Bees and beekeeping in Santo Domingo. Amer. Bee. Jour. 68:63. 1928.

Sechrist, E. L. Beekeeping in Haiti and the Dominican Republic. Amer. Bcc Jour. 63:167-170. 1923.

55 Donald, G. K. Guatemalan honey industry. U. S. Dept. Agr. Burr. Agr. Econ. Honey No. 299. Market News Service, semimonthly report. Washington, D. C. Nov. 1, 1930. (Mimeo.)

Holland, Philip. Bee industry in Guatemala. U. S. Dept. Agr. Bur. Agr. Econ. Honey No. 198. Market News Service, semimonthly report. Washington, D. C. Aug. 16, 1926. (Mimeo.)

56 Schnare, Lester L. German market for honey. American Consulate-General, Hamburg, Germany. Report No. 158.

57 Information and estimates furnished the authors by C. B. Gooderham [Canada], Dominion apiarist. 
1925 to 1930 the estimated production increased from about 19 to approximately 31 million pounds. A large part of this increase was accounted for in the rapid development of beekeeping in the prairie provinces and it resulted in the older producing areas in the East being forced to look abroad for a market.

The marketing of honey in Ontario and Quebee is handled coöperatively, in part, and a very satisfactory reputation for quality ${ }^{58}$ has been built up both locally and abroad. Ontario producers have made progress in popularizing their product in the inexpensive metal pail. Clover honeys are of leading importance among the various floral varieties. Production methods are similar to those of the United States.

Like California in North America, Chile in South America is the most important producing area from the standpoint of world trade. Beekeeping in Chile as in other South American countries is handicapped, however, by high prices for modern bee supplies; by the distance to markets; and by the uncertainty which arises from dependence on foreign outlets.

Chilean honey appears on both the German and British markets, and in quality apparently ranks somewhat above the product from Cuba while inferior to Guatemalan and California honey. Alfalfa is a leading floral source.

Small quantities of honey from Argentina find their way to world markets in most years. ${ }^{53}$ Nectar plants and climatic requirements are satisfactory for beekeeping, but cost of equipment and uncertainty of markets abroad are somewhat limiting factors. In 1927 estimates of the Argentine Director of Rural Economy ${ }^{60}$ showed that approximately onethird of the hives in use were of the fixed-frame type.

Bee culture is well established in New Zealand and is capable of considerable expansion. According to the New Zealand Official Yearbook ${ }^{61}$ "The dairying lands of the Dominion are eminently suited for the raising of bees, and a very high-grade product is put on the market from the local apiaries. The export trade is of course small when compared to the main primary industries but is capable of considerable development."

In the export trade New Zealand furnishes an example of quality and siandardization. Like other agricultural products, export of honey is under rigorous supervision and must conform to high standards of

58 [Great Britain] Imperial Economic Committee. Report of the Imperial Eco. nomic Committee on marketing and preparing for market of foodstuffs produced within the Empire. Seventh Report-Honey. London. H. M. Stat. Off. p. 68. 1928.

59 Hughes, Leo. G. Beekeeping in the Argentine. Amer. Bee Jour. 65:16. 1925.

60 Reported in: U. S. Dept. Agr. Bur. Agr. Econ. Honey No. 249. Market News Service, semimonthly report. Washington, D. C. Oct. 1, 1928. (Mimeo.)

61 Census and Statistics Office of Dominion of New Zealand. New Zealand Official Yearbook 1932:405. Wellington [N. Z.]. Dec. 15, 1931. 
quality before it is permitted to leave the country. The New Zealand product, which goes largely to the United Kingdom, is further watched on that market to prevent adulteration or malpractice and it is judiciously advertised to the British consumer. As a result of this system of handling, it has come to enjoy an enviable reputation for quality and dependability on the British market with its price (fig. 24, p. 77) in keeping with this reputation.

Production in Australia is but slightly in excess of domestic consump1ion, the surplus going chiefly to the British market. While production is undoubtedly capable of considerable expansion, there is no significant trend in this direction. ${ }^{62}$

Considerable quantities of honey from the Union of Socialist Soviet Republics (Russia) have come on the German and British markets since 1927. The Russian press reports plans for expansion of beekeeping in conjunction with the expansion of fruit growing. ${ }^{63}$ Honey from this source has been regarded as of very good quality, ${ }^{64}$ although there is undoubtedly much room for development of more modern production methods. ${ }^{65}$

A number of other countries figure in a minor way in the world trade in honey. Among these are Brazil, France, Spain, Portugal, and countries (other than those mentioned) which border on the Mediterranean. The volume exported from these countries is, however, limited.

\section{BEESWAX}

Production.-Beeswax is a by-product ${ }^{66}$ of honey production, obtained from cappings removed in extracted-honey production and from broken, undesirable, and disease-infected combs. The secretion of a pound of beeswax is estimated to require the digestion and transformation of from 7 to 20 pounds of honey by bees, according to conditions.

62 Commonwealth Bureau of Census and Statistics [Australia]. Official Yearbook 1930:531-533. Canberra [Australia]. Dec. 2, 1930.

63 Steere, Loyd V. Notes on Russian production and export of honey. Reported in: U. S. Dept. Agr. Bur. Agr. Econ. Honey, No. 329. Market News Service, semimonthly report. Washington, D. C. Feb. 1, 1932. (Mimeo.)

64 Schnare, Lester L. German market for honey. American Consulate-General, Hamburg, Germany. Report No. 158.

65 See: Santlov, A. A., and Louis Segal. Soviet Union Yearbook, 1929:105. London, George Allen \& Unwin Ltd. July, 1929.

66 Enterprises that stand in the relation to each other of using the same raw materials, like the coke and gas enterprises of a gas plant, or which come part of the way at least out of the same production process, like honey and beeswax from bees, are said to be joint-product enterprises. In cases where one of the products is more important than the rest or represents the principal object of the production process, like honey, it is ordinarily referred to as the main product, and the other product, like beeswax, as a by-product. 
Noninfected, perfectly drawn combs are far more valuable to the beekeeper than the market value of the salvaged wax. The labor required to render wax from combs is poorly compensated by the usual selling price of beeswax. Production is therefore not considered especially profitable in the United States.

Beeswax obtained from cappings in extracted-honey production is estimated to approximate 1.2 per cent of the honey tomnage ${ }^{67}$ (ratio of $1: 83.3)$. In apiary practice this ratio would be narrowed by salvage of broken or disease-infected combs or if cappings are cut deep. It is probable that increased knowledge of beekeeping has resulted in more careful culling out and salvaging of unfit and drone combs. Comb-honey production permits recovery of very little wax, and changes in the proportion of the production of this form of honey tend to influence the wax-honey ratio. The greater the proportion of comb honey the wider the ratio of wax to honey.

The only available key to the wax-honey ratio of production in the United States is the various census reports from 1859 to 1919 (table 19). While these returns are representative only of farm production a radical change in ratio of wax to honey production since 1900 is indicated.

Approximately 5 pounds of beeswax in the form of comb $b^{68}$ and cappings are required to hold 100 pounds of honey. Before the advent of the honey extractor a large part of the crop was prepared for market by melting the combs and separating honey from wax by straining. The 1859 ratio was $1: 17$ (table 19). By 1889 basic changes in production methods had widened this ratio to $1: 55$.

Since 1900 the ratio of wax to honey shows considerable widening, owing to increased production of extracted honey ( $p .85)$ and better beekeeping methods. The present ratio is probably about $1: 68$. If honey production in the United States averages $188,000,000$ pounds (table 19), that of beeswax would approximate 2,750,000 pounds.

Future beeswax production will likely be influenced, as in the past, by changes in production forms and methods. At present, there appears to be some increase in cut-comb-honey production which would tend to widen the ratio. On the other hand, if disease continues to increase, the ratio will be narrowed on account of the increased salvaging of wax from infected combs. However, if some satisfactory method of sterilizing infected combs is discovered or if there is a general improvement in disease conditions, wax production will undoubtedly decrease.

67 Dadant, II. C. Practical hints on saving beeswax. Illinois State Beekeepers' Assoc. Aun. Rept. 28:42. 1928.

$68 \Lambda$ standard size extracting comb contains about $1 / 4$ pound of beeswax and will hold between 5 and 6 pounds of honey. 
The California wax-honey ratio has differed considerably from that of the United States as a whole, probably on account of differences in production methods. California produces extracted honey mainly, and the dry summer weather permits extracting before the cells are fully capped, without much danger of fermentation. These factors would tend to widen the ratio.

TABLE 19

Ratio of Beeswax to Honey Production, Unitho States and California as RePoR'Ted By The Census, 1859-1919; Annual Estimates, 1927-1931

\begin{tabular}{|c|c|c|c|c|c|c|}
\hline \multirow{2}{*}{ Production year } & \multicolumn{3}{|c|}{ United States } & \multicolumn{3}{|c|}{ California } \\
\hline & $\begin{array}{c}\text { Honey } \\
\text { production }\end{array}$ & $\begin{array}{c}\text { Wax } \\
\text { production }\end{array}$ & $\begin{array}{l}\text { Ratio of } \\
\text { wax to boney } \\
\text { production }\end{array}$ & $\begin{array}{c}\text { Honey } \\
\text { production }\end{array}$ & $\begin{array}{l}\text { Wax } \\
\text { production }\end{array}$ & $\begin{array}{c}\text { Ratio of } \\
\text { wax to honey } \\
\text { production }\end{array}$ \\
\hline & $\begin{array}{c}\text { thousand } \\
\text { pounds }\end{array}$ & $\begin{array}{c}\text { thousand } \\
\text { pounds }\end{array}$ & & $\begin{array}{c}\text { thousand } \\
\text { pounds }\end{array}$ & $\begin{array}{c}\text { thousand } \\
\text { pounds }\end{array}$ & \\
\hline \multicolumn{7}{|l|}{ Census data: } \\
\hline $1859 \ldots \ldots \ldots \ldots \ldots$ & 23,366 & 1,323 & $1: 17.7$ & 12 & 1 & $1: 21.0$ \\
\hline $1869 \ldots .$. & 14,703 & 631 & $1: 23.3$ & 294 & 5 & $1: 60.0$ \\
\hline $1879 \ldots$ & 25,743 & 1,106 & $1: 23.3$ & 574 & 15 & $1: 39.1$ \\
\hline $1889 \ldots \ldots$ & 63,897 & 1,167 & $1: 54.8$ & 3,930 & 62 & $1: 63.1$ \\
\hline $1899 \ldots \ldots$ & 61,196 & 1,765 & $1: 34.7$ & 3,668 & 115 & $1: 31.8$ \\
\hline $1909 \ldots .$. & 54,815 & 905 & $1: 60.6$ & 10,265 & 126 & $1: 81.2$ \\
\hline $1919 \ldots$. & 55,244 & 821 & $1: 67.3$ & 5,502 & 107 & $1: 51.5$ \\
\hline \multicolumn{7}{|l|}{ Annual estimates: } \\
\hline $1927 \ldots \ldots$ & ............. & ............. & .............. & 17,149 & 342 & $1: 50.2$ \\
\hline $1928 \ldots .$. & 215,000 & 3,160 & $1: 68.0$ & 18,000 & 246 & $1: 73.3$ \\
\hline $1929 \ldots$ & 211,000 & 3,100 & $1: 68.0$ & 15,375 & 220 & $1: 75.0$ \\
\hline $1930 \ldots$ & 169,000 & 2,500 & $1: 68.0$ & 15,426 & 186 & $1: 82.9$ \\
\hline $1931 \ldots .$. & 160,000 & 2,350 & $1: 68.0$ & 14,315 & 174 & $1: 82.5$ \\
\hline
\end{tabular}

Sources of data:

1859-1919: Honey and wax production as reported in the United States Census.

1927: Estimated production for California from: Todd, Frank E. Apiary inspection. California State Dept. Agr. Mo. Bul. 19: 880. 1930.

1928-1931: Estimated by authors based upon registration, returns.

The 1859 ratio in California (1:21) approximated that for strained honey. During the next decade the Harbison hive came into general use in the state, increasing the production of comb honey, and this is reflected in the wide ratio of $1: 60$, in 1869. Rapid changes in the form of honey produced after 1906 and the development of new areas, such as Imperial Valley (where extracted honey only is produced) probably widened the ratio ( $1: 81$ ), in 1909. Increase of disease and the recovery of beeswax from infected combs again narrowed the ratio in 1919 to $1: 52$.

The 1927 ratio approximated that for 1919, being $1: 50$. Following the passage of the Apiary Inspection Act in 1927, beekeepers made a special effort to clean up disease. As disease conditions improved, the wax-honey ratio has been widened considerably. The 1930 (1:83) approximates that ordinarily obtained from cappings. 
The wax-honey ratio may be expected to remain at about $1: 80$. Unless there is an increase in disease, a change in the method of eradication required by the bee law, a change in form of honey produced, or a definite trend in honey production, none of which appear likely at the present time, beeswax production of California may be expected to average about 200,000 pounds a year, fluctuating with variations in the total honey erop.

Domestic Beeswax Prices.-Numerous varieties and sources of beeswax make for difficulties in compiling prices. T'he data in table 20 represent the average cash quotations for California beeswax. ${ }^{69}$ 'I'he rise during the War period was relatively far less than that for general commodities or for honey. From the latter part of 1921 through 1924 prices were approximately on a pre-war level. From a peak in 1926 there was a continuous decline until the summer of 1932 when prices were less than one-third of the pre-war level and approximately one-fourth of those in 1926. This income source has been reduced relatively more than that of honey and most other agricultural products.

Several reasons can be mentioned for the exceptionally low domestic prices which have prevailed during recent years. Substitution of vegetable and mineral waxes for beeswax and, in many instances, the interchangeability of the three products have had a share in the relatively low levels. The record low prices ${ }^{i 0}$ of 1931 and 1932 have been closely related to the lowering of the general price level and to the decline in industrial activity. Disturbances in the monetary standards of many of the foreign nations exporting beeswax to the United States undoubtedly have accelerated the decline in domestic prices.

Quotations on Foreign Beeswax and Carnauba Wax.-California producers are interested in foreign beeswax quotations at New York, because they materially affect prices in the West. Although the United States has been on a net import basis since 1900 (p. 91), it is significant that prior to the World War quotations ${ }^{71}$ at New York were generally

69 Several checks on the data show that they are substantially correct. The average value of wax in California as reported in 1909 and 1919 censuses was $\$ 0.27$ and $\$ 0.39$ respectively. Records furnished through the courtesy of H. L. Weens, Bakersfield, California, show the following priees paid in the San Joaquin Valley for large lots of wax.

\begin{tabular}{|c|c|}
\hline & l'IRICF \\
\hline YEAR & PER P'OUND \\
\hline 1897. & $\ldots \ldots \$ 0.25$ \\
\hline $1898 \ldots . . .$. & $\ldots . . .25$ \\
\hline $1899 \ldots .$. & ... 0.25 \\
\hline $1900 \ldots$. & $\$ 0.26$ \\
\hline
\end{tabular}

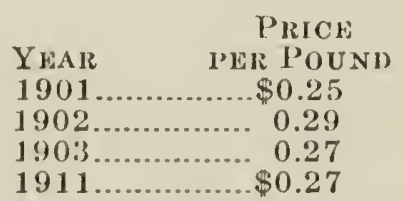

\begin{tabular}{|c|c|}
\hline & PIRICE \\
\hline YEAIR & PER POUND \\
\hline 1913. & $\ldots \ldots \$ 0.30$ \\
\hline 1916 & 0.28 \\
\hline 1918 & $\ldots \$ 0.38$ \\
\hline
\end{tabular}

70) An examination of the average export value of beeswax shows that it fell below $\$ 0.20$ a pound only once between 1860 and 1923 . In 1890 the average export value was $\$ 0.115$.

7 Quotations appear regularly in: Producers Price Current and the New York llaily Jomal of Commerce, both published daily in New York City. 
made on domestic beeswax; quotations on foreign beeswax appearing only intermittently from 1910 through 1922. Beginning in the latter year, foreign beeswax quotations were published regularly while in the same year those on domestic beeswax became intermittent, and since 1924 they have not been made regularly. During the period when domestic and foreign beeswax prices were both quoted the former were usually higher than the latter, although this may have been the result of dissimilar grading.

TABLE 20

Average Prices Paid Producers for Wax in California, 1918-1933

(Cents per pound)

\begin{tabular}{|c|c|c|c|c|c|c|c|c|c|c|c|c|c|}
\hline Year & Jan. & Feb. & Mar. & April & May & June & July & Aug. & Sept. & Oct. & Nov. & Dec. & $\begin{array}{l}\text { A ver- } \\
\text { age }^{*}\end{array}$ \\
\hline 1918 & $-\dagger$ & - & - & 一 & - & 35 & 35 & 35 & 36 & 36 & 36 & 37 & - \\
\hline 1919 & 38 & 37 & 39 & 40 & 36 & 38 & 40 & 40 & 40 & 40 & 40 & 40 & 39 \\
\hline 1920 & 41 & 42 & 42 & 41 & 41 & 42 & 43 & 42 & 42 & 42 & 42 & 40 & 42 \\
\hline 1921 & 37 & 34 & 34 & 33 & 28 & 31 & 31 & - & - & 20 & - & 22 & 30 \\
\hline 1922. & 23 & 24 & 23 & 一 & - & 一 & 23 & 22 & 20 & 20 & 22 & 24 & 22 \\
\hline 1923 & 26 & 27 & 28 & 27 & 27 & 28 & 27 & 25 & 20 & 23 & 21 & 22 & 25 \\
\hline 1924 & 22 & 24 & - & 23 & 23 & 24 & 22 & 22 & 22 & 23 & 23 & 24 & 23 \\
\hline 1925. & 24 & 25 & 27 & 29 & 29 & 30 & 28 & 29 & 29 & 28 & 30 & 33 & 28 \\
\hline 1926. & 36 & 36 & 35 & 37 & 35 & 35 & 36 & 32 & 34 & 32 & 32 & 34 & 35 \\
\hline 1927. & 34 & 35 & 34 & 34 & 34 & 34 & 33 & 33 & 30 & 30 & 31 & 31 & 33 \\
\hline 1928. & 33 & 31 & 32 & 31 & 31 & 31 & 32 & 31 & 32 & 31 & 31 & 31 & 31 \\
\hline 1929. & 31 & 33 & 33 & 32 & 30 & 29 & 28 & 28 & 27 & 27 & 27 & 28 & 29 \\
\hline 1930 . & 30 & 26 & 26 & 27 & 25 & 23 & 19 & 19 & 19 & 19 & 19 & 19 & 23 \\
\hline 1931. & 20 & 18 & 18 & 16 & 16 & 16 & 15 & 14 & 14 & 12 & 12 & 12 & 15 \\
\hline 1932. & 12 & 12 & 12 & 12 & 11 & 11 & 9 & 9 & 10 & 9 & 9 & 9 & 10 \\
\hline 1933 & 9 & 9 & 9 & 8 & 9 & 11 & 11 & 13 & 15 & 16 & & & \\
\hline
\end{tabular}

* Unweighted average. † Dashes indicate data not available.

Source of data:

Computations by authors based upon cash quotations for beeswax in California as published in honey reports of the Federal-State Market News Service, semimonthly issues.

From 1921 to 1928 Chilean beeswax commanded the highest quotations on the New York market although prices were quoted on beeswax of various origins. In July, 1931, quotations were published on imported wax without reference to the origin. Evidently quality had become more uniform. From available data, the differential between the light and medium, and between the nedium and dark beeswaxes has varied from 2 to 3 cents a pound (table 21 ).

Carnauba wax is probably the clief vegetable competitor of beeswax. Imported in sizable amounts for a considerable period of time, prices have been quoted at New York for the past two decades, but owing to the varying grades it is impossible to obtain comparable series of data. A comparison of Caruauba wax quotations with those on foreign beeswax does not reveal close short-time correspondence, although the general movements are the same. 
The future trend of prices is problematical. Should technical discoveries making for the substitution of beeswax by other waxes continue, the outlook would be less favorable than if the present state of technic prevails. Attention is called, however, to the higher price of beeswax at

TABLE 21

Wholesale Quotations on Foreign Beeswax and Carnauba Wax a'T NEW YORK, 1923-1932

\begin{tabular}{|c|c|c|c|c|c|}
\hline \multirow{2}{*}{ Year } & \multicolumn{3}{|c|}{ West Indies beeswax } & \multicolumn{2}{|c|}{ Carnauba wax } \\
\hline & Light & Medium & Dark & No. $1^{*}$ & No. 3 N.C.* \\
\hline \multicolumn{6}{|c|}{ Cents per pound } \\
\hline $1923 \ldots \ldots \ldots . .$. & 26.7 & .......... & 21.5 & 42.2 & 19.0 \\
\hline $1924 \ldots \ldots \ldots$ & 30.0 & .......... & 250 & 38.5 & 21.5 \\
\hline $1925 \ldots$ & 40.9 & .......... & 37.0 & 38.5 & 30.3 \\
\hline $1926 \ldots \ldots$ & 43.8 & 39.4 & 37.8 & 51.9 & 38.9 \\
\hline $1927 \ldots \ldots \ldots$ & 41.4 & 39.1 & 36.5 & 58.1 & 31.6 \\
\hline $1928 \ldots \ldots \ldots$ & 40.5 & 37.8 & 35.2 & 503 & 28.2 \\
\hline $1929 \ldots \ldots \ldots$ & 38.0 & 35.6 & 336 & 36.3 & 25.0 \\
\hline $1930 \ldots \ldots \ldots$ & 31.0 & 28.3 & 263 & 29.4 & 20.7 \\
\hline $1931 \ldots \ldots \ldots \ldots$ & 26.9 & 24.8 & 228 & 322 & 14.0 \\
\hline $1932 \nmid \ldots \ldots \ldots \ldots \ldots$ & 18.4 & 16.4 & 14.5 & 23.2 & 12.0 \\
\hline
\end{tabular}

Relative quotations, $1926=100$

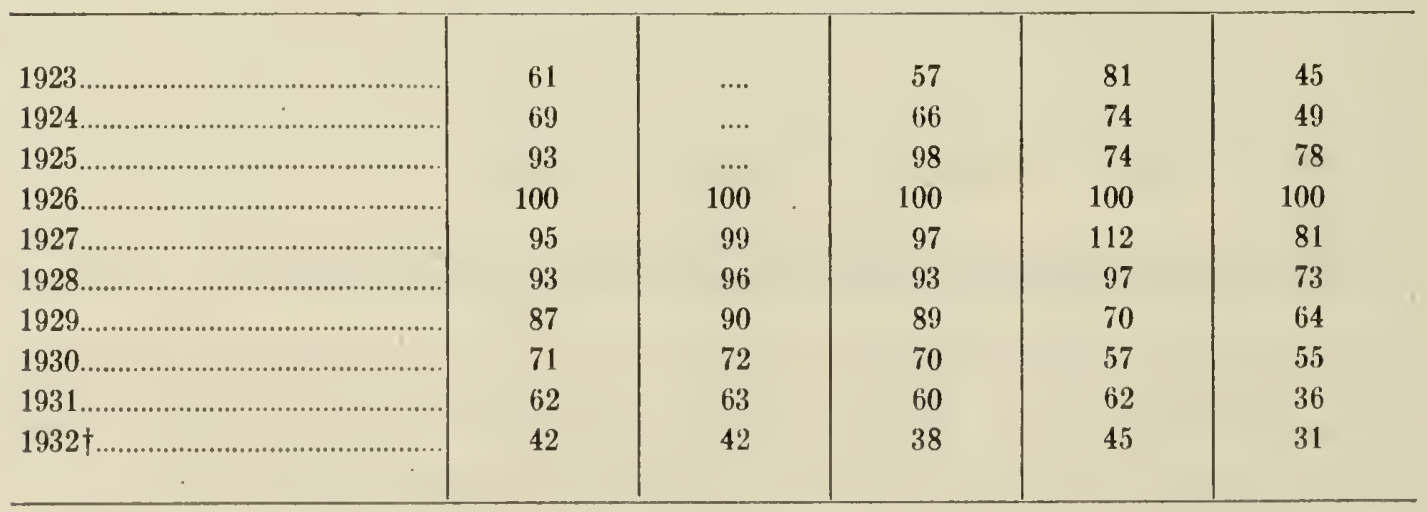

* No. 1 Carnauba is the highest grade. No. 3 N. C. is the lowest grade and includes also chalky Carnauba wax. "N. C." refers to "north country" wax.

t In 1932 quotations were not differentiated according to place of origin. The quotations given are for imported beeswax.

Source of data:

Computations by authors based upon monthly quotations in: the Ncw York Daily Journal of Commerce.

present, as compared to those of most of the substitutes for it. Business conditions and the general price level probably influence wax prices more than technological changes.

Uses of Beeswax.-Interest of beekeepers in the utilization of beeswax caused the Bureau of Entomology of the United States Department of Agriculture to make inquiries among some of the larger users concern- 
ing amounts used, changes in use, together with noted differences between the foreign and domestic product. Questionnaires were sent to 61 firms using beeswax and of these 51 replied. A total of 3,052,019 pounds of beeswax was reported as being used by these firms in 1931. Specific uses were reported for 1,369,141 pounds, many firms being unable to estimate the amounts used in different products. The imports in 1931 totaled $3,680,000$ pounds (table 22, p. 92 ), and if the domestic production was approximately 2,350,000 pounds the returns obtained repreesented approximately 51 per cent of the combined production and importation for that year. Specific uses reported represented approximately 23 per cent of the combined production and imports.

Care must be exercised in drawing conclusions from a sample such as that obtained because a few firms may use the bulk of the beeswax for a specific purpose or product and the omission of data from one firm might lead to erroneous conclusions. Of the replies obtained, the largest uses were in making comb foundation and candles. The manufacturers of comb foundation, as might be expected, have the most complete representation in the sample because of their particular interest in the bee and honey industry. Large uses were reported in the manufacture of cosmetics and pharmaceutical preparations, and in the manufacture of polishes, paints, and varnishes. Contrary to popular belief the use of beeswax in the electrical industries is probably not great.

There are a large number of other uses to which beeswax is put. Through the courtesy of various manufacturers the following products and industries are mentioned as using sizable amounts of beeswax:

binder for composition
bricks for buffing
candles
carbon paper
comb foundation
composition wax
confectionery
cosmetics
cutlery manufacturing
dental wax
electrical industries
encaustic painting
floor polish
glassware manufacturing

grafting wax

lithographic ink

laundries

leather cement

lithographic crayons

mastic varnish

metal composition polish

modeling

naval stores

pattern making

pharmaceutical preparations (such as ointments and cerates) phonograph records

process engraving and

lithographing

sail making

sealing wax

shoe polish

shoe repairing

tailoring

textiles

waterproofing

winter-sports equipment

glassware manufacturing

It is also used for obtaining impressions from cuts and designs, and also as "resists" when etchings are made by the use of acids.

The above list clearly shows how both industry changes and general business conditions would influence the consumption and hence the 
prices. Beekeepers are naturally interested in knowing whether or not technological changes have increased or decreased in the demand for beeswax. There seems to have been a number of these changes which have caused a falling off in demand in certain industries. In the bee and honey industry itself, some manufacturers are using, in combination with beeswax, a small percentage of plant wax and perhaps mineral wax, in some instances, to give greater strength to comb foundation. In the electrical industry technological changes have undonbtedly made for changes in demand. A number of industries have adopted paraffin in place of beeswax on account of the lower cost. In the telephone industry the best information with reference to technological changes can be obtained from the following : ${ }^{2}$

For the impregnation of switchboard wiring forms made of wire having textile insulation, either a mixture of beeswax and paraffin or a white mineral wax is used. Both materials give satisfactory results and the use of one or the other is determined by the market conditions obtaining.

A recent development is the provision of a textile insulation treated with cellulose acetate which requires no impregnation. This type of insulation is being introduced into the plant for certain types of wiring forms, and it may be found iesirable to extend the application of this type of insulation to a major part of the forms now receiving wax impregnation.

From the above it can be seen that it would be difficult to estimate the demand for beeswax over any period as it is dependent not only on the market conditions, but also on the extent of the application of the cellulose acetate treated insulation.

Although all the above statements would indicate that substitutes are being made for beeswax in technological processes, the fact remains that over a period of years the apparent consumption of beeswax has increased. In all probability beeswax is being used in processes in which other waxes were formerly utilized.

Imports and Exports of Wax.-Competition between waxes of animal, vegetable, and mineral origin in their various uses makes it difficult to ascertain the underlying reasons for changes in the trend of imports and exports. The classification of certain waxes has been changed, complicating the analysis of foreign trade. The California beekeeper is especially concerned with the demand for honey in foreign countries and with the supplies of wax originating abroad. 'The United States is an exporter of honey and an importer of beeswax.

Beeswax is imported as "beeswax, crude and animal wax" and as "beeswax bleached, and manufactured." Imports of the bleached product are insignificant from a value standpoint.

72 Letter from Willam II. Harrison, Plant Engineer of the American Telephone. and Telegraph Company, to the authors, Jamury 18, 1932. 
Prior to 1900 the United States generally showed a net yearly export of beeswax. Net imports rose rapidly and steadily from approximately 21,000 pounds in the fiscal year 1900-01 to a peak of over $5,065,000$ pounds in 1928-29. During the following three years an appreciable falling off took place.

A noticeable change in the origin of the imports has occurred during the past two decades. Prior to the War the chief countries of origin were Cuba, Germany, and the Dominican Republic. The War gave an impetus to imports from several countries of the Western Hemisphere-Brazil, Mexico, and Chile. With the increased imports occurring since 1920 the origin of imports has widened and can be found in many different political subdivisions of the world. Since the War European trade has come back to a prominent place while the trade with countries of the New World has continued. Prior to the War, Russia imported enormous quantities of wax for use in the Orthodox Eastern Church. Since the War and Revolution this trade has ceased and the wax produced has found other outlets.

Since 1925 the chief countries sending beeswax to the United States have been Brazil, Portugal, Cuha, United Kingdom, Mexico, Dominican Republic, Chile, Germany, and Egypt. Sizable imports have been r'eported from French Africa, British East Africa, and Portuguese Africa since 1927. With the exception of the United Kingdom and Germany, which in all probability reëxport wax originating elsewhere, tropical or subtropical conditions and crude production methods usually prevail over most of the areas in which imports originate and the development of industry has not been so rapid as in northwest Europe and North America. Furthermore. in some of these countries beekeeping does not utilize the wax produced as it does in the United States. Practically all of the beeswax imported enters via eastern ports.

Imports of beeswax during the years 1928-1932 averaged slightly ovel $4,000,000$ pounds (table 22 ). If domestic production averaged $2,750,000$ pounds annually it is probable that during these years foreign beeswax furnished approximately four-sevenths of the amount consumed. While the trend in the imports of crude heeswax has been upward, actual imports have been less than the total of either vegetable or mineral waxes.

Carnauba wax, the chief vegetable competitor of beeswax among the vegetable waxes, as previously noted (page 87), is obtained from the Carnauba or wax palm. This palm grows in northern Brazil over a large area, indicating that there are potential production resources. Previous to the War the greater part was sold in Germany, but during the War the imports shifted to the United States where they enter free of duty. 
Carnauba wax imports were first separated from other vegetable waxes in 1928 (table 22). During 1928-1931 there has been a steady increase in imports. The impetus given the imports of vegetable waxes occurred in 1916-1918, during which time the wax trade with Europe was seriously curtailed. The average vegetable-wax imports of 1927-1931 were over double those of the five pre-war years.

\section{TABLE 22}

General Imports of Beeswax and Vegetable Wax into the United States, Fiscal Years 1909-10 to 1913-14, CALENDAR Years 1920 to 1932

(Thousands of pounds, i.e., 000 omitted)

\begin{tabular}{|c|c|c|c|c|c|c|c|}
\hline \multirow{2}{*}{ Year } & \multirow{2}{*}{ Beeswax } & \multicolumn{2}{|c|}{ Vegetable wax } & \multirow{2}{*}{ Year } & \multirow{2}{*}{ Beeswax } & \multicolumn{2}{|c|}{ Vegetable wax } \\
\hline & & Carnauba & Total & & & Carnauba & Total \\
\hline $\begin{array}{l}\text { Pre-war: } \\
\text { 1909-10... }\end{array}$ & 972 & * & 5,241 & $\begin{array}{l}\text { Post-war-(Contd.): } \\
1923\end{array}$ & 3,571 & $*$ & 9.739 \\
\hline $1910-11 \ldots$ & 903 & * & 4,282 & $1924 \ldots$ & 3,096 & $*$ & 7,865 \\
\hline $1911-12$. & 1,077 & * & 4,666 & $1925 \ldots$. & 3,557 & $*$ & 6,507 \\
\hline $1912-13 \ldots$ & 829 & * & 5,653 & $1926 \ldots \ldots \ldots \ldots \ldots \ldots$ & 4,622 & $*$ & 8,234 \\
\hline $1913-14 \ldots$ & 1,412 & * & 4,256 & $1927 .$. & 5,041 & $*$ & 10,150 \\
\hline & & & & 1928 & 4,402 & 5,471 & 9,483 \\
\hline Post-war: & & & & $1929 \ldots$ & 5,258 & 6,849 & 11,467 \\
\hline $1920 \ldots$ & 4,143 & $*$ & 6,554 & 1930. & 4,312 & 7,416 & $9,89 ?$ \\
\hline $1921 \ldots$ & 2,493 & * & 6,701 & $1931 \ldots \ldots \ldots \ldots \ldots$ & 3,680 & 7,447 & 10,095 \\
\hline 1922 & 3,183 & * & 7,706 & $1932 \ldots$ & 3,466 & .......... & ............ \\
\hline
\end{tabular}

* Not segregated prior to 1928.

Source of data:

U. S. Dept. Com. Foreign Commerce and Navigation of the United States 1910-1914, 1920-1932.

By far the most important "wax" imports are those of "paraffin and paraffin wax" which together averaged over 36 million pounds during 1929-1931. There has been a pronounced increase in imports, originating largely in India and the Dutch East Indies, over the past decade. Imports of all waxes appear insignificant when compared with the exports of paraffin wax, both unrefined and refined, from the United States. No pronounced trend is evident with the unrefined product over the past decade, but there apparently has been a steady decline in the exports of the refined product since 1924. During the years 1928-1931 exports of the former product averaged over 84 million pounds, while for the latter 216 million pounds were reported.

"Mineral wax," also on the free list, has shown only a slight tendency to increase over the past decade averaging slightly over 10 million pounds during the period 1928-1931.

In answer to a question addressed by the author's to users of beeswax whether foreign beeswaxes possessed any properties which the American 
did not possess, opinions seemed to have been about equally divided. Of the half of those stating that foreign beeswaxes did possess superior qualities, the majority mention a greater facility of certain foreign beeswaxes to bleach while a lesser number stated that foreign waxes were more uniform than the domestic ones. Some criticism was directed against the preparation of both foreign and domestic beeswax for market.

No specific comments can be made upon the domestic trade in beeswax until more complete data are available. The only visible source of information, the Federal-State Marketing Service Reports, show some 28,000 pounds of wax shipped or exported by boat from Los Angeles in 1931 and a slightly larger amount for 1930. However, no figures are given for San Francisco on water shipments, and as wax is a commodity with at least a fairly high value in small bulk, it might be reasonable to assume that some quantity is sent east by rail.

\section{QUEEN PRODUCTION}

Colonies normally requeen themselves when the queen is lost or "fails" on account of old age, injury, etc. However, since honey production may be increased by using selected stock and since timely requeening can circumvent production losses caused by failing or inefficient queens, there arises a yearly demand for queens. Commercial honey producers usually endeavor to requeen all colonies at one or two-year intervals. Queens are shipped by mail in specially constructed, small wooden cages and must be accompanied by several worker bees. Queens are also included in package-bee shipments which are used to start new colonies, to requeen, or to pollinate. They are sold according to race and grade. ${ }^{i 3}$

United States.-Queen production in the United States is of greatest importance in California, Texas, and the southern districts. The White Clover Belt, at one time of predominant importance, has shown a decline in number of breeders in recent years. Queen production has become localized, to a considerable degree, in those areas that are also favorable to package-bee production (fig. 25). This has led to development of the industry in early breeding-season areas such as the southern district, Texas, Arizona, and California with a resulting decline in the mumber of queen breeders in the White Clover Belt. 'The Plains area, the inter-

73 Brecding stock are queens of proved superior ability and usually command higher prices. Tested queens have been mated and some of their progeny have emerged (over 3 weeks after egg laying begins). The breeder may determine by uniform markings that they are purely mated. They usually sell at about 25 per cent above untested queen prices. Selected tested queens are a selection of the better tested queens. Untested queens are those which have been mated and have begun to lay eggs ( 5 to 8 days after emergence), but purity of mating is unknown. The bulk of the queens sold are of the untested grade. 
mountain district, and the Pacific Northwest have never been important queen-rearing districts.

Each queen-producing district has a fairly well-defined market area. The market for the southern district is the White Clover Belt and eastern Canada; for Texas, the Plains area and contiguous territory in the intermountain district and Clover Belt, together with the central provinces of

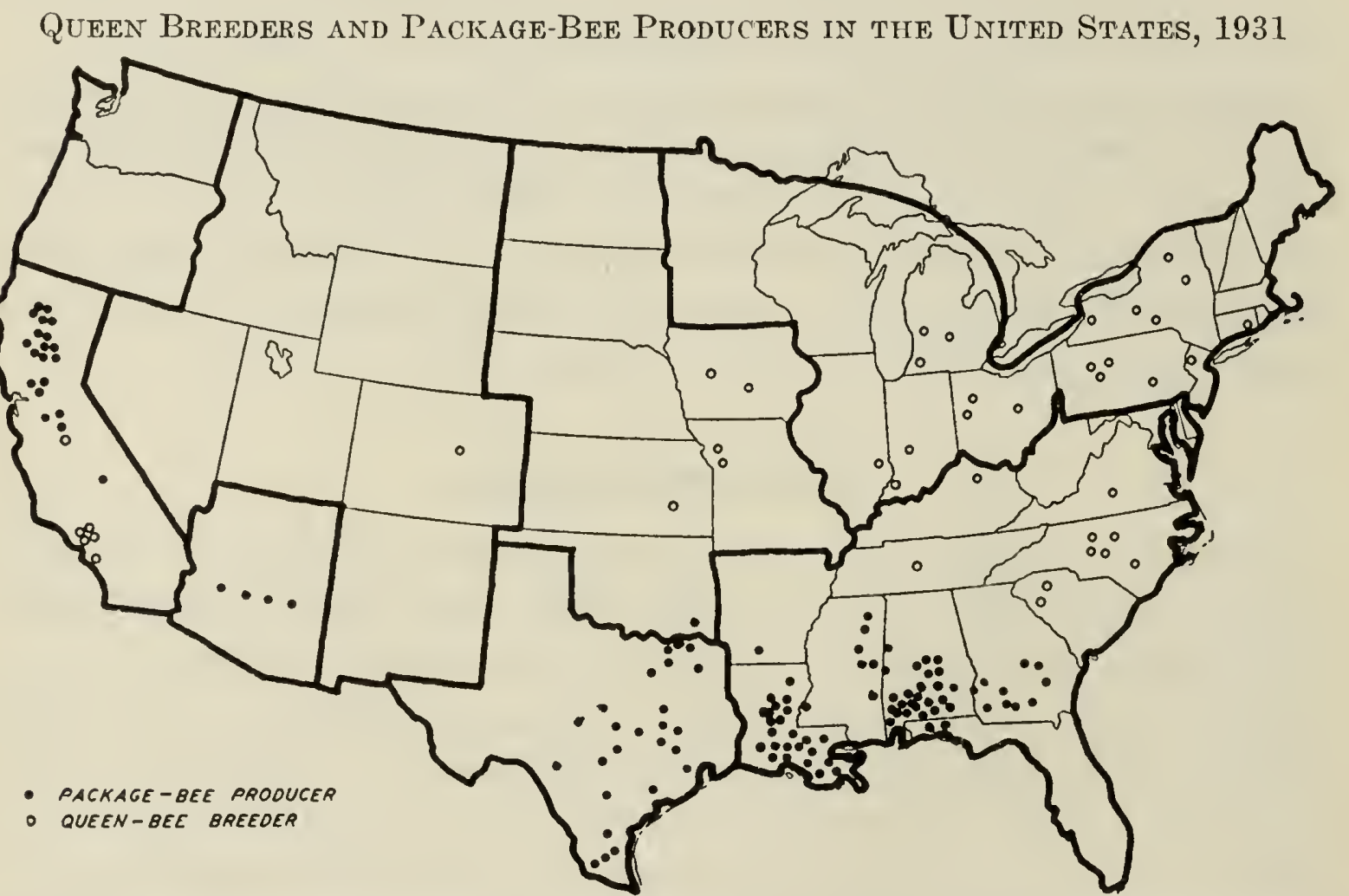

Fig. 25.-The development of the package-bee industry has caused the queenbreeding industry to move southward into the southern and Texas districts and westward into the California and Arizona districts. While the White Clover Belt still has a number of queen breeders, the number is less than those in the southern district. Note the lack of producers in the intermountain district and Plains area. Package-bee producers in most cases produce queens. (Data based upon unpublished material compiled by the authors.)

Canada; for California, the intermountain district, Pacifie Northwest, and western Canada (fig. 26). There is, however, a certain amount of overlapping, especially by producers having stock of recognized high quality.

California.-Commercial queen-breeding is a recent adjunct ${ }^{i 4}$ to California beekeeping, and its production has been doubled in the past decade (table 23). It is centered in the Sacramento Valley and in the northern end of the San Joaquin Valley where natural conditions are favorable for this specialized business (fig. 25). The character of pollen and nectar flows tend to promote early and sustained brood-rearing, a neces-

74 The development of queen production has followed closely that of package bees (page 99), although it started shortly after 1900 in the southern part of the state. 
TABLE 23

ShipMents of Queen Bees from California, 1922-1931

\begin{tabular}{|c|c|c|c|c|c|c|c|}
\hline Year & $\begin{array}{c}\text { Number } \\
\text { shipped as } \\
\text { queen bees }\end{array}$ & $\begin{array}{c}\text { Number of } \\
\text { queen bees } \\
\text { in } \\
\text { package-bee } \\
\text { shipments }\end{array}$ & Total & Year & $\begin{array}{l}\text { Number } \\
\text { shipped as } \\
\text { queen bees }\end{array}$ & $\begin{array}{c}\text { Number of } \\
\text { queen bees } \\
\text { in } \\
\text { package-bee } \\
\text { shipments }\end{array}$ & Total \\
\hline $1922 \ldots \ldots$ & 16,496 & 15,470 & 31,966 & 1927. & 13,926 & 19,745 & 33,671 \\
\hline 1923. & 13,677 & 9,440 & 23,117 & 1928. & 19,404 & 26,316 & 45,710 \\
\hline $1924 \ldots \ldots$ & 14,371 & 9,715 & 24,086 & $1929 \ldots$ & 20,723 & 37,627 & 58,350 \\
\hline $1925 \ldots \ldots \ldots$ & 10,457 & 12,187 & 22,644 & 1930. & 32,554 & 38,928 & 71,472 \\
\hline $1926 \ldots .$. & 13,907 & 14,618 & 28,525 & $1931 \ldots \ldots \ldots$ & 31,735 & 25,532 & 57,267 \\
\hline
\end{tabular}

Sources of data:

Calculations by authors based on data from questionnaires sent to leading queen shippers in California.

McElfresh, F. H., and F. E. Todd. Factors involved in extending the market for California package bees. (An unpublished report prepared by the Bureau of Commerce of the State of California, and California State Department of Agriculture for the California State Beekeepers' Association.)

Distribution of California Queen-Bee Shipmen's, 1931

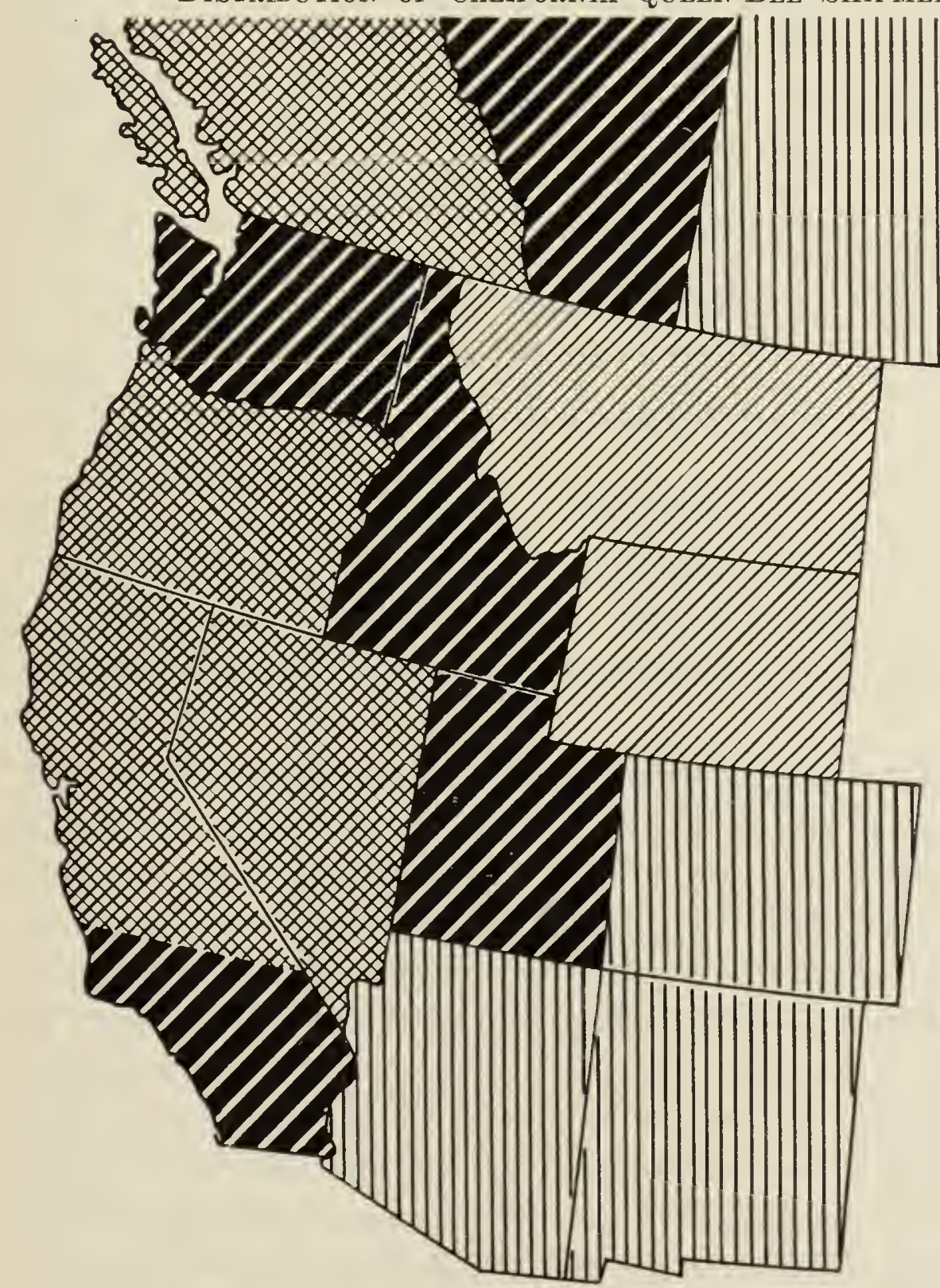

QUEEN-BEE SHIPMENTS

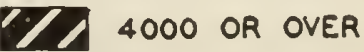

1000 To 4000

VIIA 300 To 1000

IIII UNDER 500

Fig. 26.- The eleven western states and the three western provinces of Canada form the market for California queen breeders. (Data compiled by authors from returns obtained from queen breeders.) 
sary factor in queen-rearing. California queens become available in March and are among the earliest produced in the United States; they eommand the higher prices on the market during the earlier months (fig. 27). Direct mail connections, both by land and air, with the principal markets are invaluable assets, for queens are subject to injury by long periods in transit.

TABLE 24

Monthuy Shipments of Queen Bees by Certain California Breeders, 1931

\begin{tabular}{|c|c|c|c|c|c|c|c|c|c|}
\hline State or province & March & April & May & June & July & Aug. & Sept. & Oct. & Totals \\
\hline \multicolumn{10}{|c|}{ Western United States } \\
\hline Arizona & 0 & 50 & 25 & 0 & 0 & 0 & 25 & 0 & 100 \\
\hline California (north)... & 96 & 678 & 574 & 270 & 159 & 135 & 313 & 75 & 2,300 \\
\hline California (south)... & 146 & 670 & 314 & 141 & 191 & 428 & 650 & 86 & 2,626 \\
\hline 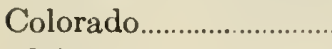 & 0 & 34 & 2 & 30 & 2 & 0 & 0 & 0 & 68 \\
\hline 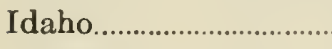 & 0 & 950 & 877 & 175 & 0 & 2 & 1 & 0 & 2,005 \\
\hline 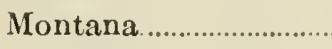 & 0 & 50 & 155 & 2 & 0 & 0 & 0 & 0 & 207 \\
\hline Nevada... & 25 & 100 & 135 & 30 & 0 & 0 & 6 & 0 & 296 \\
\hline Oregon................... & 0 & 225 & 358 & 116 & 18 & 103 & 47 & 20 & 887 \\
\hline Utah & 0 & 320 & 522 & 91 & 5 & 0 & 3 & 0 & 941 \\
\hline 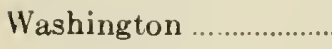 & 0 & 818 & 354 & 197 & 30 & 44 & 41 & 0 & 1,484 \\
\hline 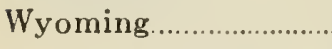 & 0 & 230 & 122 & 55 & 0 & 0 & 0 & 0 & 407 \\
\hline \multicolumn{10}{|c|}{ Western Canada } \\
\hline Alberta............. & 0 & 0 & 614 & 205 & 0 & 0 & 0 & 0 & 819 \\
\hline British Columbia.. & 10 & 1,530 & 192 & 45 & 33 & 59 & 62 & 10 & 1,941 \\
\hline Saskatchewan.................... & 0 & 2 & 3 & 0 & 0 & 0 & 0 & 0 & 5 \\
\hline \multicolumn{10}{|c|}{ Grand Total } \\
\hline & 277 & 5,657 & 4,247 & 1,357 & 438 & 771 & 1,148 & 191 & 14,086 \\
\hline
\end{tabular}

Source of data:

Information furnished by a number of California queen breeders. The authors believe the above to be representative of shipments.

Markets for California queens include the eleven western states and western Canada (fig. 26 and table 24). This territory, which is a highly developed commercial honey-producing area, contains but few commercial queen breeders outside of California. While some honey producers prefer to rear their own queens in order to have personal knowledge of quality and dependability, many prefer to devote their entire energy to honey production, and depend on commereial breeders to supply queens. 'The demands of this latter class are for a dependable supply produced with precision and care from high-quality stock, and delivered on the date required in good condition. If these wants are supplied, there is every indication that California queen production will continue to develop. 


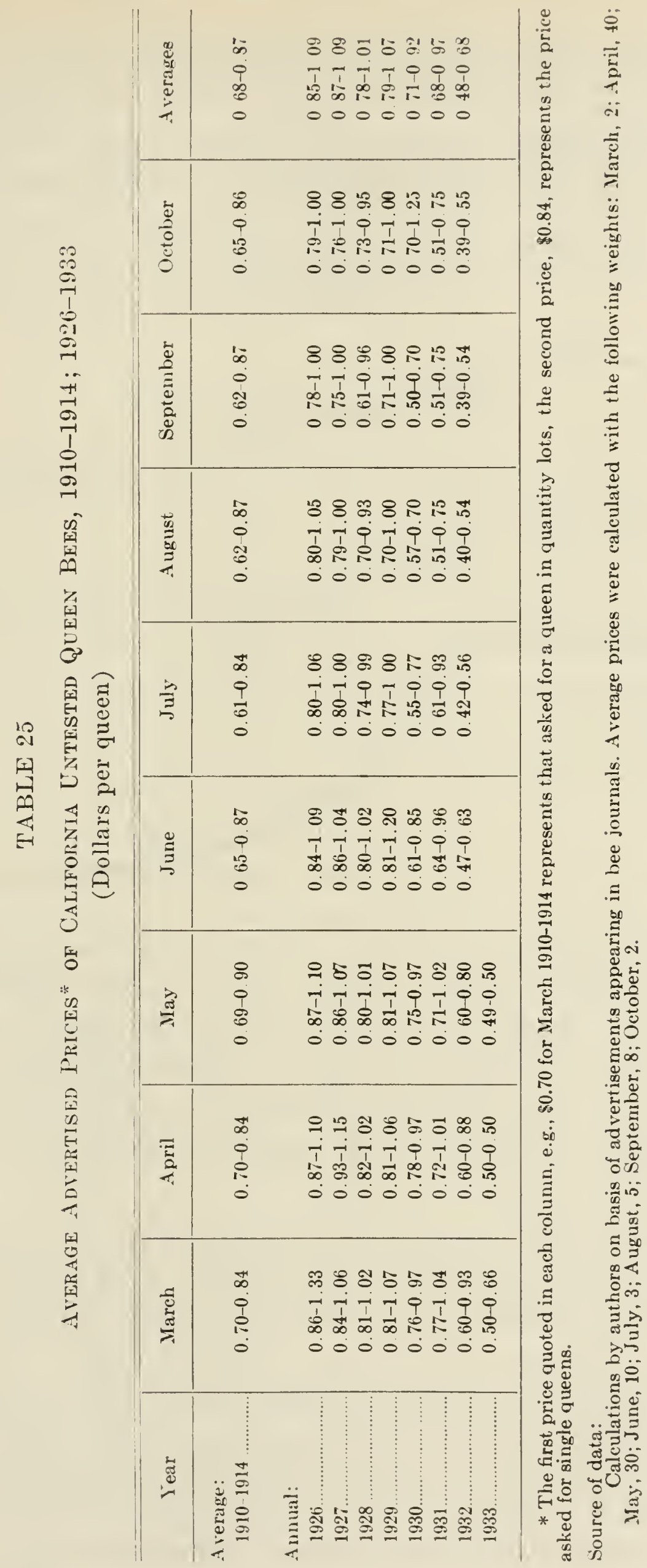


No feature of queen production is more important than stock improvement. At present there probably is little difference between districts in quality of stock produced, since inquiry indicates that there is a continual interchange of breeding stock. California queen breeders are encouraging stock improvement, and whatever progress can be made in

Prices of Queen Bees in Quantity Lots, California, Averages 1910-1914, $1926-1929,1932$

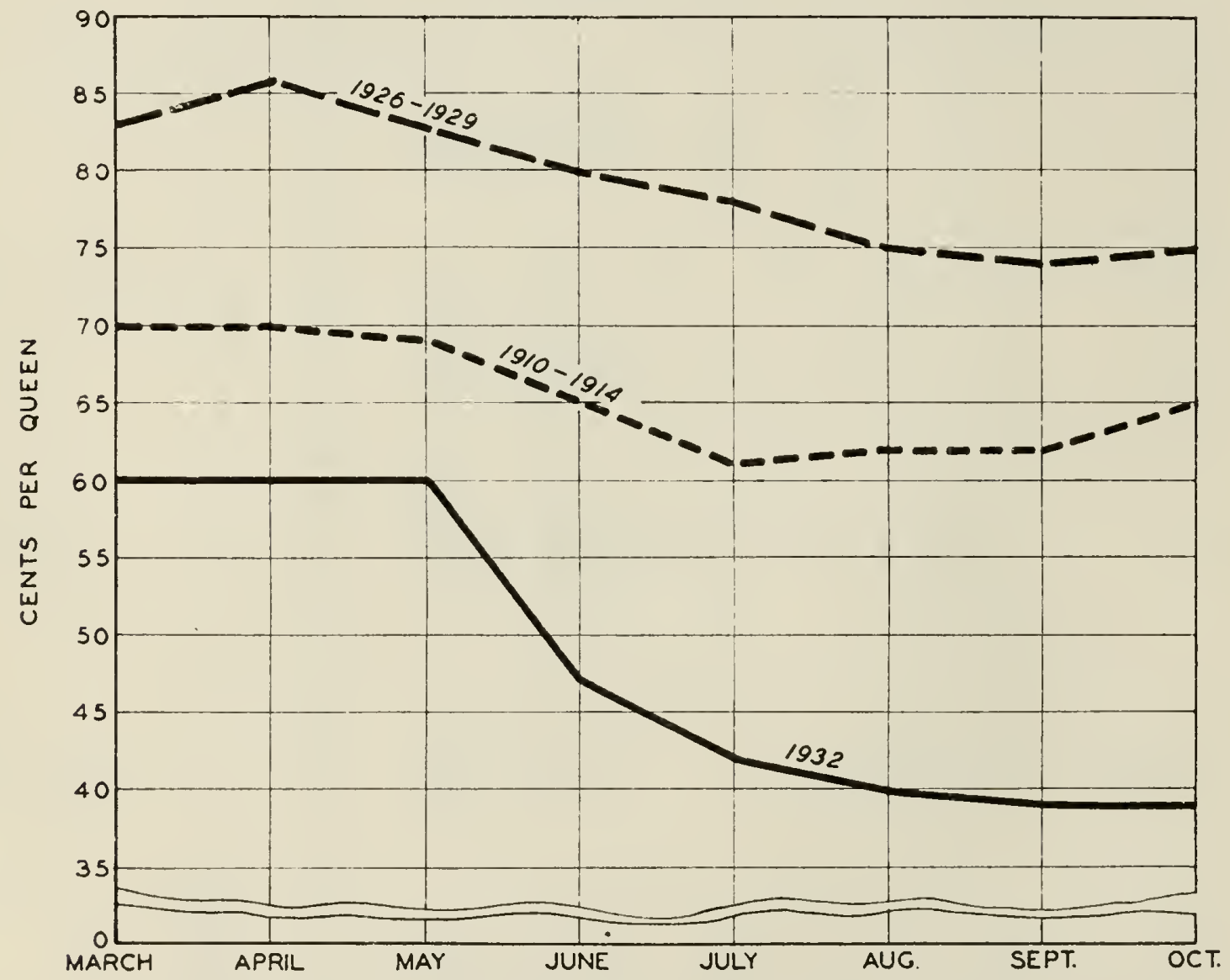

Fig. 27.-Queen-bee prices are usually higher during the spring months when they are in greater demand. While prices during 1926-1929 averaged well above those for 1910-1914, those for 1932 were loss than pre-war prices. The low prices were the result of several factors among which were the fall in the price level and the extremely low honey prices prevailing. (Data from table 25 and unpublished data for 1910-1914 compiled by the authors.)

this direction will be of far-reaching importance for they supply a wide market. No effort ean be spared in this direction since high-quality stock is the foundation on which the future queen market will be built.

Prices of California Queen Bees.-Prices of queens reached lower levels in 1932 than they have in any year since 1879. The severe decline in prices began in 1930 and continued through 1932 (table 25, fig. 27). 'There have been several contributing causes, no one of which provides a sole explanation. Commodity prices, including those for honey and other foods, have dropled. 'The beekeeper, confronted with lower returns, en- 
deavors to cut costs wherever possible and the demand for queen bees slackens. The rapid increase in the number produced may account for some of the decline.

Higher prices for queen bees generally prevail during March, April, and May when the bulk of the shipments are made (fig. 27). Prices usually start downward in June and in past years have reached a low point in September. During some years there is a slight increase in the October price as compared with that in September.

\section{PACKAGE-BEE PRODUCTION}

The production of bees for shipment in combless screen cages has become a specialized branch of bee culture in the United States. Commercial development started in $1912^{75}$ as a solution to the problem of shipping bees without infringing upon state regulations which prevented the entry of bees on combs. Successful shipping of package bees was found to depend upon properly proportioned food sirup (sugar and water), dependable feeding cans, adequate ventilation, and reasonable protection against extremes of temperature. Since the solution of the shipping problems by which losses have been practically eliminated, the demand for package bees has increased phenomenally because their use eliminates some of the greatest hazards in beekeeping.

Conditions required for success in the package-bee enterprise are exacting. Advantageous factors for production are: (1) conditions favorable for building up strong colonies of bees during early spring, ${ }^{i 6}$ not followed by major honey flows on which to use them; (2) nearness to markets; (3) suitable rail connections; (4) equipment and conditions favorable to queen production (page 94) or proximity to a dependable supply of quality stock; (5) freedom from bee disease.

The purchaser of package bees has certain requirements that must be met by the successful shipper. To derive full benefit from the bees, they must be received at a definite time, which varies with the number of bees in the package and the locality. ${ }^{77}$ Safe and prompt delivery are of the utmost importance, for delay in receipt of a shipment or a replacenient may reduce the crop materially.

75 Unsuccessful experiments in shipping package bees were made by A. I. Root in 1879 in an endeavor to find a means of reducing costs of shipping bees.

76 Experiments have shown that instead of the common collception of 6 weeks, it requires from 8 to 9 weeks to build package bees into honey-producing colonies. For this reason the demand for package bees has been shifting to periods earlier in the year.

77 Nolan, W. J. The development of package-bee colonies. U. S. Dept. Agr. Tech. Bul. 309:1-44. 1932. 
There are no standard grades for package bees. They are sold in cages containing 2,3 , or 5 pounds of bees and one queen. Honey producers prefer either a 2 or 3 -pound package, according to local conditions. Three pounds of bees with the queen is considered the equal of the average wintered colony in the early spring. For fruit pollination a 5-pound package of bees is desired. Cages for package-bee shipping are standardized, ${ }^{i 8}$ but those for pollination are still in the experimental stage.

TABLE 26

Method oh Shipping California Package Bees, 1926-1933

\begin{tabular}{|c|c|c|c|c|c|c|c|}
\hline \multirow[b]{2}{*}{ Year } & \multicolumn{3}{|c|}{ Number shipped by } & \multirow[b]{2}{*}{ Year } & \multicolumn{3}{|c|}{ Number shipped by } \\
\hline & $\begin{array}{c}\text { Parcel } \\
\text { post }\end{array}$ & Express & Truck & & $\begin{array}{c}\text { Parcel } \\
\text { post }\end{array}$ & Express & Truck \\
\hline 1926. & 55 & 14,563 & - * & $1930 \ldots$ & 363 & 35,865 & 2,700 \\
\hline $1927 \ldots$ & - & 19,745 & - & $1931 \ldots$ & 2,968 & 18,927 & 3,637 \\
\hline $1928 \ldots$ & 4 & 26,212 & 100 & 1932 & 415 & 24,602 & 3,400 \\
\hline $1929 \ldots \ldots$ & 91 & 34,650 & 2,886 & 1933. & 730 & 23,633 & 4,913 \\
\hline
\end{tabular}

* Dashes indicate data not available, but amount probably small.

Source of data:

McElfresh, F. H., and F. E. Todd. Factors involved in extending the market for California package bees. An unpublished report prepared by the California Bureau of Commerce, and California State Department of Agriculture, for the California State Beekeepers' Association.

United States.-The main centers for package-bee production are California, Alabama, Georgia, Louisiana, Mississippi, and Texas. Small amounts originate in Arizona, Florida, and North and South Carolina (fig. 25). Markets supplied by each area are well defined; the southern and Texas districts supplying the Clover Belt, Plains area, Ontario, and Ianitoba; the California district supplying the eleven western states and the western provinces of Canada.

The total shipments in $1930^{79}$ were approximately 130 tons net weight, composed of about 80,000 packages. Nearly half the shipments originated in California, while Alabama was the principal shipping state in the South. Losses are practically negligible and this is of importance to purchasers. No doubt this factor had an influence on shipment increases.

Prices of package bees f.o.b. shipping points in a given season are

38 Whitcomb, Warren. Recommendations for shipping eages for bees. U. S. Dept. Agr., Southern States Field Station. E-287:10. (Mimeo.)

79 Unpublished data on file in the Library of Congress, Washington, D. C., gathered for the Southern States Beekeepers' Conference by Kennith Hawkins, G. B. Lewis Company, Watertown, Wisconsin; and for the California State Beekeepers' Association, by F. II. MeElfresh, California Bureau of Commerce, and Frank E. 'Todd, California State Department of Agriculture, showed that the thirty-six principal producers in the southern states and Texas shipped 38,627 packages, and the thirty-five principal California producers shipped 38,938 . It is probable that the California returns were more inclusive. 
fairly uniform thronghout the country. Delivered costs vary with transportation distances; and shipments are made by mail, truck, and express, but the latter accounts for the larger part (table 26). In 1931 packagebee shippers were able to reduce transportation costs by a third (as of May 15,1932 ) by obtaining a reclassification of express rates for package bees in standard cages. This may have a stimulating influence on the

TABIA 27

Markeis for Calikoria PaCkage BeEs, 1930-1933

\begin{tabular}{|c|c|c|c|c|c|c|c|c|}
\hline \multirow{2}{*}{ Destination } & \multicolumn{2}{|c|}{1930} & \multicolumn{2}{|c|}{1931} & \multicolumn{2}{|c|}{1932} & \multicolumn{2}{|c|}{1933} \\
\hline & $\begin{array}{l}\text { Packages } \\
\text { shipped }\end{array}$ & $\begin{array}{l}\text { Per } \\
\text { cent }\end{array}$ & $\begin{array}{l}\text { Packages } \\
\text { shipped }\end{array}$ & $\begin{array}{l}\text { Per } \\
\text { cent }\end{array}$ & $\begin{array}{l}\text { Packages } \\
\text { shipped }\end{array}$ & $\begin{array}{l}\text { Per } \\
\text { cent }\end{array}$ & $\begin{array}{l}\text { Packages } \\
\text { shipped }\end{array}$ & $\begin{array}{l}\text { Per } \\
\text { cent }\end{array}$ \\
\hline Arizona ........ & 202 & 05 & 5 & ......... & 50 & 0.2 & 50 & 02 \\
\hline California. & 2,628 & 6.7 & 1.213 & 47 & 1,128 & 40 & 1,020 & 35 \\
\hline Colorado .... & 319 & 0.8 & $2 j$ & 0.1 & 211 & 0.7 & 20.5 & 07 \\
\hline 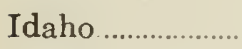 & 10,511 & 270 & 4,261 & 167 & 4,115 & 145 & 4,560 & 156 \\
\hline Utah ...................... & 5,839 & 150 & 3,640 & 143 & 5,400 & 19.0 & 6,046 & 206 \\
\hline Nevada ......... & 1,830 & 47 & 750 & 29 & 1,325 & 4.7 & 1,070 & 37 \\
\hline New Mexico... & 19 & 01 & $\ldots .$. & $\ldots$. & 2.5 & 01 & 2.5 & 01 \\
\hline Montana ............ & 2,028 & 52 & 737 & 29 & 1.390 & 49 & 1,525 & 52 \\
\hline Washington & 2,355 & 61 & 3,538 & 139 & 2,971 & 104 & 3,045 & 104 \\
\hline 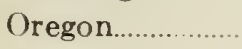 & $1.92 \pi$ & 49 & 458 & 18 & 1,295 & 46 & 1,295 & 44 \\
\hline Wyoming....... & 409 & 10 & 641 & 25 & 1.150 & 40 & 1,175 & 40 \\
\hline Canada...... & 10,744 & 276 & 9,845 & 386 & $i, 8.57$ & $2 \bar{i} 6$ & 7,470 & 25.5 \\
\hline Other*...... & 117 & 0.3 & 419 & 1.6 & 1,500 & 53 & 1,800 & 6.1 \\
\hline Total... & 38,928 & 100.0 & 25,532 & 100.0 & $28,41 i$ & 100.0 & 29,276 & 1000 \\
\hline
\end{tabular}

* Alaska, Kansas, Missouri, Nebraska, North Dakota, Oklahoma, south Dakota.

Source of data:

McElfresh, F. H.: and F. E. Todd. Factors involved in extending the market for California package bees. An unpublished report prepared by the California Bureau of Commerce, and California State Department of Agriculture, for the California State Beekeepers' Association.

demand for package bees. Improvement and cheapening of air transportation may extend the radius within which bees may be sent. The cost of transportation is an important point in determining markets. ${ }^{80}$

California.-Package-bee production centers largely in the Sacramento and northern San Joaquin valleys (fig. 25), where manzanita, fruit bloom, and wild flowers (fig. 5 ) stimulate brood-rearing in January and February and the colonies build up strength rapidly. In most years package-bee shipping may begin as early as March 20. No major honey flow is available for these strong colonies, which normally become reduced in strength during the May dearth and must be built up again for the alfalfa and star-thistle flow later in the year. Because of these conditions a surplus of bees is available for package shipping. No other method

80 Package bees are sent f.o.b. California shipping points. The landed cost is an important consideration to the purchaser. While the arerage haul is at present about 700 miles, some are much longer, viz., those to Canada. 
of utilization has been found. Possibilities of expanding supplies are considerable, for there are estimated to be at least 300 tons of bees available, with less than a fifth now being utilized.

The demand for California package bees has steadily increased, with but few notable exceptions (fig. 28). Since 1920 there has been a general

Packages of Bees Shipped from California, 1913-1931, AND PRICE PER PACKAGE, 1919-1931

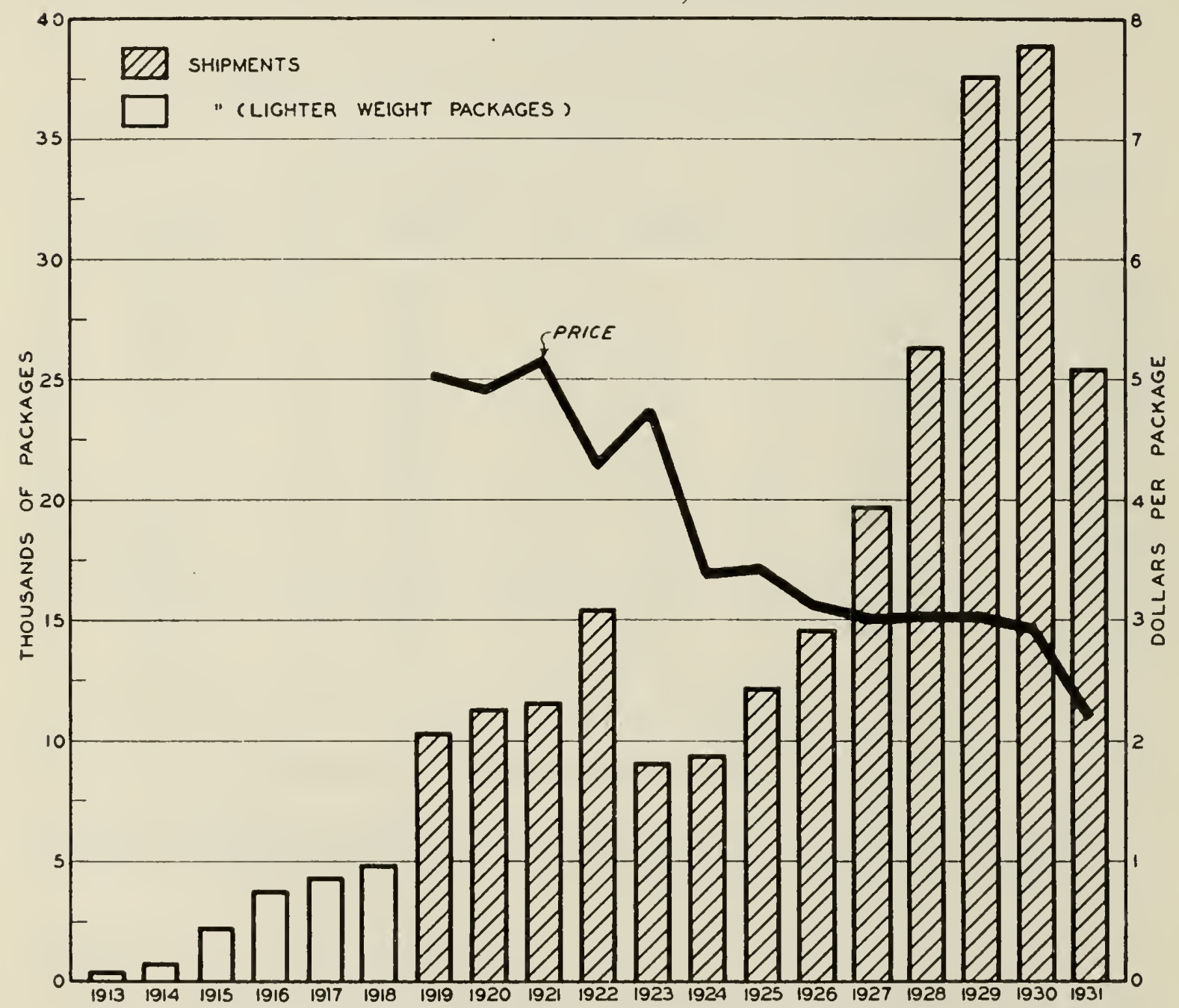

Fig. 28.- Since 1913 a sizable trade has been built up by the California shippers of package bees. From 1913 to 1918 the weights (bees) per package were considerably lower than those prevailing since the latter date. With the increase in shipments the price per package has fallen steadily. All prices are f.o.b. and include the queen. (Data from: MeElfresh, F. H., and F. E. Todd. Factors involved in extending the market for California package bees. An unpublished report prepared by the California Bureau of Commeree and the California State Department of Agriculture for the California State Beekeepers' Association.)

II) ward trend in shipments, a high point being reached in 1930 when apmoximately 60 tons of bees (net) were shipped.

The market area for California package bees includes all the beekeping territory of the West (table 27 ). Quantity taken is influenced from rear to year hy winter losses, honey prices, and other eonditions. Advance reports on winter losses in various states are of value to shippers 
in estimating the probable demand for package bees. Prior to 1926 practically all shipments were sent by express, but since then increasing amounts have been diverted to parcel post and trucks.

Available data on selling prices of package bees do not permit detailed study because advertised prices cannot be taken as representative of the actual sales price. The average value per package shown in fig. $28 \mathrm{in-}$ volves two variables, the value of the queen and the number of pounds in the package. In recent years there has been a trend from a 2 to a 3-pound (net) package. Although the average weight of the package plus bees was relatively high ${ }^{81}$ (6.87 pounds) in 1931, the average selling price was the lowest in the twelve-year period recorded.

While the growth of package-bee shipping has been fairly constant and shippers have made progress in the satisfactory delivery of theil product, there is still an abundant supply of bees in California which are not marketed. Quality of stock is of greatest importance, no less so than in queen-rearing. Possible improvements undoubtedly will influence the future development of markets.

Utilization of Package Bees.-Package bees are used by honey producers to recoup winter losses, to increase the honey production of weak colonies, and to expand the honey enterprise rapidly. In the more rigorous climates some beekeepers kill their colonies in the fall, avoiding the expense of wintering, and replace them the following spring with package bees. This practice permits the sale of honey that would otherwise be used as winter stores, and has helped make commercial honey production practical in new areas. Before package bees came into use, recouping losses or expanding the honey enterprise, in most areas, was done at the expense of the honey crop, any considerable expansion requiring a period of years. By using package bees, the enterprise can now be expanded at will, with a corresponding increase in the honey crop in the same season.

\section{RENTING BEES FOR POLLINATION}

The honeybee is probably of far greater value in its pollination services than in producing honey and wax. Pollination is contributed incidentally wherever the bees are present, but there are fruit areas in California where the distribution and numbers of bees are insufficient to pollinate the bloom properly. This deficiency has been made up to some extent by renting colonies from a beekeeper during the blossoming time or by purchasing package bees. The practice of renting bees in some

81 The package now used weighs about 2 pounds, the feed about 2 pounds, and the lees 2 or 3 pounds, total weight being 6 or 7 pounds. 
localities serves to increase the beekeeper's income, but in others it is unattractive.

Spray poison, buckeye (which is poisonous to bees) in some areas, and bee disease in others have done much to discourage beekeeping by fruit growers. Many beekeepers refuse to rent bees for pollination in areas where there are possibilities of poisoning or disease, because it does not pay to take the risk involved for a small rental fee.

TABLE 28

Frutt Acreages with Pollination Problem in California Honey Belts, 1932

\begin{tabular}{|c|c|c|c|c|c|c|c|c|}
\hline \multirow{2}{*}{ Fruit } & \multicolumn{3}{|c|}{ South coast and chaparral } & \multicolumn{2}{|c|}{$\begin{array}{l}\text { Sacramento- } \\
\text { San Joaquin }\end{array}$} & \multirow{2}{*}{$\begin{array}{l}\text { Trans- } \\
\text { mountain } \\
\text { belt III }\end{array}$} & \multirow{2}{*}{$\begin{array}{l}\text { Bay } \\
\text { region } \\
\text { and } \\
\text { cut-over } \\
\text { redwood } \\
\text { area, } \\
\text { belt IV }\end{array}$} & \multirow{2}{*}{ Total } \\
\hline & Belt I $a$ & Belt $\mathrm{I} b$ & Belt I $c$ & Belt II $a$ & Belt II $b$ & & & \\
\hline Almond.... & 1,722 & 204 & 19,538 & 11,371 & 32,643 & 0 & 5,420 & 70,898 \\
\hline Apple.......................... & 3,949 & 1,139 & 2,150 & 4,049 & 2,797 & 794 & 28,697 & 43,575 \\
\hline A vocado... & 1,815 & 2,233 & 124 & 7 & 7 & 0 & 2 & 4,198 \\
\hline Cherry....... & 1,349 & 20 & 88 & 3,430 & 3,577 & 22 & 5,216 & 13,702 \\
\hline Pear ........................ & 4,738 & 444 & 3,643 & 2,139 & 27,481 & 88 & 31,015 & 69,548 \\
\hline Plum and prune.... & 1,372 & 305 & 10,221 & 21,871 & 57,844 & 56 & 12,008 & 103,677 \\
\hline Persimmon........ & 1,269 & 261 & 4 & 278 & 385 & 2 & 14 & 2,213 \\
\hline 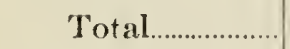 & 16,214 & 4,606 & 35,778 & 43,145 & 124,734 & 962 & 82,372 & 307,811 \\
\hline
\end{tabular}

Source of data:

Blair, R. E. Acreage estimates-California fruit and nut crops. 1927-1932. California State Dept. Agr. Special Pub. 117: 32. 1932.

Less than 16 per cent of the beekeepers that answered a questionnaire reported renting bees for pollination. This seems to indicate that this phase of the industry is relatively unimportant in most parts of California. It is most prevalent in the Sacramento-San Joaquin belt, where about 55 per cent of the state's deciduous-fruit acreage, having a pollination problem, ${ }^{82}$ is located (table 28 ).

In the southern San Joaquin Valley a deficiency of bees is not felt by the fruit growers, and the beekeepers rent fruit locations on which to build up their bees for the orange nectar flow. In the northern end of the Valley the ratio of bees to fruit acreage shows a deficiency of bees, and there is no orange or other honey flow on which to use built-up colonies, therefore, the fruit grower rents bees for pollination.

In deciduous fruit and almond-growing areas of the Sacramento Val-

82 Philp, G. I., and G. H. Vansell. Pollination of deciduous fruit by bees. California $\Lambda$ gr. Ext. Cir. 62:4. 1932. The fruit grower has a pollination problem with ilmonds, cherries, plums and prunes, apples, pears, and berries. In general, apricots, peaches, and walnuts set well with their own pollen, and hence present no lifficulties from this standpoint. The .J. H. Hale peach, however, is self-unfruitful and must be interplanted with some other variety. 
ley there is a deficiency of bees; it is here that the practice of renting bees for pollination has been most highly developed. Some beekeepers are so situated that they can rent the same bees for pollination two or three times during a season, as, for example, to the almond grower, then to the cherry, prune, and plum growers in the Valley, and later to the pear and plum growers in the mountain sections.

Honey production in belt IV is relatively unimportant, but since there are about 82,000 acres of fruit (table 28) and only 12,000 colonies of bees, the desirable ratio of bees to fruit acreages is not obtained. This

TABLE 29

Rentat, Fees Regeived by Beekeepers for Fruit Pollination, 1925-1931

\begin{tabular}{|c|c|c|c|c|c|c|c|}
\hline Year & Records & $\begin{array}{c}\text { Colonies } \\
\text { included } \\
\text { in the } \\
\text { average }\end{array}$ & $\begin{array}{l}\text { A verage } \\
\text { rent per } \\
\text { colony, } \\
\text { in dollars }\end{array}$ & Year & Records & $\begin{array}{l}\text { Colonies } \\
\text { included } \\
\text { in the } \\
\text { average }\end{array}$ & $\begin{array}{l}\text { A verage } \\
\text { rent per } \\
\text { colony, } \\
\text { in dollars }\end{array}$ \\
\hline $1925 \ldots$ & 5 & 1,340 & 212 & $1929 \ldots$ & 8 & 2,048 & 175 \\
\hline $1926 \ldots$ & 4 & 1,540 & 2.06 & 1930. & 12 & 3,388 & 1.67 \\
\hline $1927 \ldots \ldots \ldots$ & 6 & 2,078 & 1.92 & 1931. & 18 & 7,147 & 161 \\
\hline $1928 \ldots \ldots \ldots$ & 7 & 2,659 & 1.64 & & & & \\
\hline
\end{tabular}

Sources of data:

Records collected by G. H. Vansell in interviews with beekeepers renting bees for fruit pollination in Sacramento, San Joaquin, Napa, Pajaro, and Santa Clara valleys, for almond, apple, cherry, plum, prune, persinimon, and pear trees.

district is located at some distance from commercial honey-production centers, and therefore, the transportation costs for rented colonies are necessarily high, which makes rental unattractive to beekeepers. A similar situation exists along the coast north of Santa Barbara County. Jn such areas package bees may be used to solve the pollination problem. In the avocado areas of southern California bees are maintained by some of the growers for pollination purposes. As the need for avocado pollination is continuous, no short rental period is possible, but there might be opportunity for beekeepers to rent bees on a yearly basis.

Little or no surplus honey is stored from fruit bloom, except at times from the prune. ${ }^{83}$ Fruit bloom does stimulate brood-rearing, but in those sections of California where renting bees for pollination is practiced, the surplus bees are of no value to the bee man, unless they can be sold as package bees. In the vast majority of cases the only return to the beekeeper from pollination work is the fee paid by the fruit grower minus the cost of transportation and the labor of caring for the bees. Where the rental fee is high and the transportation cost is low, the bee-

83 Prune honey is not only low in quality, but ferments readily. The comb in which it has been stored may produce fermentation in other honey stored in the same combs later in the year. 
keeper seeks this source of income. Unfortunately, all California fruit areas are not situated near important centers of honey production, but such isolated areas offer markets for package bees.

Table 29 shows records obtained from beekeepers of rental fees paid for pollination. Because of the factors involved in renting bees, such as variation in benefits received by the beekeeper, distance of hauling bees, and competition for business, variation in rental fees is considerable.

\section{COST FACTORS IN HONEY AND BEESWAX PRODUCTION}

Prices of honey and beeswax alone may give a one-sided view of the economic conditions in the industry. Beekeepers are not only interested in prices of the product, but since the ultimate or primary objective is maximum total profits or maximum increase in the net worth of the business from a long-time point of view, costs enter into the consideration. High prices for honey and beeswax do not necessarily mean prosperity, nor low prices unprofitableness, for the beekeeper. If the prices received for honey and beeswax are high as compared with his costs, the beekeeper is prosperous; if they are low as compared with his costs, he is not prosperous. It is understood, in this case, that costs include all debt charges. In the long run, the representative commercial producer will obtain the costs of production, or, failing in this, he will turn to some other line of endeavor.

Studies conducted by Sechrist ${ }^{8 t}$ and Kifer in the intermountain states indicate that among the cash-outlay items the principal ones were those for labor, supplies and equipment, motor cars and trucks. Although the results indicate that these items varied greatly in the apiaries of different size, they stand out above others. The Agricultural Extension Service ${ }^{85}$ of the University of California reports that in Orange County "All Labor" and "All Material" made up over 65 per cent of the costs on five apiaries during four year's. Rasmussen ${ }^{86}$ in his studies of prices of honey, states that bee supplies and wages of farm labor make up a large portion of the cost of producing honey.

Labor.-While the item of labor is difficult to appraise, general trends

84 Sechrist, F. L., and R. S. Kifer. Preliminary report on apiary organization and honey production in the intermountain states in 1928. Unnumbered publication issued by the U. S. Dept. Agr. Bur. of Ent. and the Bur. Agr. Econ. 18 p. 1929. (Mimeo.)

85 'The Agricultural Extension Service, University of California, and the Beekeepers Departinent of the Orange County Farm Bureau. Summary of cost and efficiency analysis on honey production, Orange County, 1931. Unnumbered report issued by the $\Lambda \mathrm{gr}$. Ext. Ser. of the University of California. 8 p. 1932. (Mimeo.)

se Rasmussen, M. P. Prices of honey, bee supplies, and farm wages. Farm Eeom. $3: 1147-1152.1929$. 
in wages can be indicated. Different conclusions can be drawn from data, according to whether a beekeeper is an employer of labor or whether the labor is done by himself and his family. In the latter case the labor income is such that from data available it is impossible to even approximate a trend. In cases where labor has been hired, the wages paid would in all probability most closely correspond with general farm wages.

In California the relative general-farm-wage level during the five years 1917-1921 was lower than the relative price of honey during those years (when both sets of relative prices are based upon the pre-war years 1910-1914). This, coupled with the comparatively favorable vields during these years, accounts in part for the activity on the part of those intending to enter the business of producing honey. Apparently during 1924 and 1925 prices of honey were again relatively higher than farm wages. It is erroneous to conclude that because this was the case the beekeeper was prosperous. Comparisons are made between relative unit prices of honey and relative wages. With data on the volume of product lacking, it is difficult to show anything but trends in unit prices.

Since 1925 the relative wholesale price of honey has been lower than the relative farm wages on a 1910-1914 base. This is not peculiar to the honey industry since this situation has prevailed with most agricultural products. To the individual beekeeper employing labor, a decline in the price received for his product, occurring at a more rapid rate than a decline in wages paid, cause unusual difficulties. This condition is, and has been, causing difficulties over a period of years in agriculture, and since 1929 similar difficulties have been encountered in many other industries. It is highly probable that in most instances beekeeper's do their own work. This simply means that in many cases the operators have, since 1925 , been receiving an inadequate wage for the work done.

Equipment and Supplies.-Innumerable items occur under this caption but hives and foundation are found on the lists of purchases of most California beekeepers. Other supplies and articles of equipment, such as sections, wooden cases, bottles, cans, extractors, etc., are purchased, but in a study of this type it is not possible to go into further details. A complete series of data on the unit costs of materials required for the assembling of 8 and 10 -frame hives have been obtained (table 30 ). These include no labor charges for setting up the hives. With certain exceptions, the relatives prices of hives since the War have been higher than the relative prices of honey. Although hive prices have declined from the peak reached in 1921, the relative decline has been less than that of honey. In 1930, 1931, and 1932 more extracted honey was required to equal in value an 8 or 10 -frame hive than in 1910-1914 (fig. 29). This has been 
the unfortunate, but usual relation between raw, or unmanufactured, products and manufactured products since the War. In other words, the relation between the commodities (usually raw materials) which farmers have sold and those which they have purchased (often manufactured products) has been unfavorable to the former group during this period.

TABLE 30

A ('Tual and Relative Prices of Materials Used in 8 and 10-Frane Hives (K. D.), * United States, 1910-1932

\begin{tabular}{|c|c|c|c|c|}
\hline \multirow{2}{*}{ Year } & \multicolumn{2}{|c|}{ Actual prices $\dagger$} & \multicolumn{2}{|c|}{ Relative prices $-1910-1914=100$} \\
\hline & 10-frame & 8-frame & 10-frame & 8 -frame \\
\hline $1910 \ldots \ldots \ldots$ & $\$ 3.38$ & $\$ 2.94$ & 96 & 96 \\
\hline $1911 \ldots \ldots \ldots$ & 3.49 & 3.04 & 99 & 99 \\
\hline $1912 \ldots \ldots \ldots . . . .$. & 3.52 & 3.06 & 100 & 100 \\
\hline $1913 \ldots \ldots \ldots . . . .$. & 3.52 & 3.06 & 100 & 100 \\
\hline $1914 \ldots \ldots \ldots . . .$. & 3.70 & 3.21 & 105 & 105 \\
\hline $1915 \ldots \ldots \ldots$ & 3.74 & 3.26 & 106 & 107 \\
\hline $1916 \ldots \ldots \ldots$ & 3.54 & 3.00 & 101 & 98 \\
\hline $1917 \ldots \ldots \ldots$ & 3.58 & 3.04 & 102 & 99 \\
\hline $1918 \ldots \ldots \ldots$ & 4.46 & 3.81 & 127 & 124 \\
\hline 1919. & 4.89 & 4.22 & 139 & 138 \\
\hline $1920 \ldots \ldots \ldots$ & 5.71 & 4.99 & 162 & 163 \\
\hline $1921 \ldots \ldots \ldots . .$. & 7.32 & 6.39 & 208 & 209 \\
\hline $1922 \ldots \ldots \ldots$ & 4.51 & 3.93 & 128 & 128 \\
\hline $1923 \ldots \ldots \ldots$ & 4.88 & 4.16 & 139 & 136 \\
\hline $1924 \ldots \ldots \ldots \ldots$ & 5. 20 & 4.44 & 148 & 145 \\
\hline $1925 \ldots \ldots \ldots \ldots$ & 5.42 & 4.62 & 154 & 151 \\
\hline $1926 \ldots \ldots \ldots \ldots$ & 5.62 & 4.82 & 160 & 157 \\
\hline $1927 \ldots \ldots \ldots \ldots$ & 5.62 & 4.82 & 160 & 157 \\
\hline $1928 \ldots \ldots \ldots \ldots$ & 5.45 & 4.64 & 155 & 152 \\
\hline $1929 \ldots \ldots \ldots \ldots$ & 5.43 & 4.62 & 154 & 151 \\
\hline $1930 \ldots \ldots \ldots$ & 5.50 & 4.73 & 156 & 155 \\
\hline $1931 \ldots \ldots \ldots \ldots$ & 4.60 & 404 & 131 & 132 \\
\hline 1932 & $\$ 4.28$ & $\$ 3.78$ & 122 & 123 \\
\hline
\end{tabular}

* K. D. = "Knocked down."

f In the calculation of the price of an 8-frame hive the following items have been included: 2 supers, $16 \mathrm{Hoffman}$ frames, 1 cover, 1 bottom, 2 pounds foundation. For a 10 -frame hive the following were included: 2 supers, 20 Hoffman frames, 1 cover, 1 bottom, $2 \frac{1}{2}$ pounds foundation.

Source of data:

Calculations by authors based upon catalogs issued by bec-supply companies.

'T'able 30 indicates that the price of a hive in 1932 was approximately 20 per cent higher than it was in 1910-1914 while honey prices were generally Jower.

Comb foundation is purchased yearly to a greater or lesser extent by the producers of extracted honey and it is a yearly item in the budget of comb-honey producers. Where disease is prevalent, expenditures are larger than would otherwise be the case. $\Lambda$ comparison between the relative prices of foundation and honey shows the same general relation as that which exists between hive costs and honey prices. 
Because of the wide use of cans and wooden shipping cases, prices are of especial interest to California beekeepers. As compared with the relative prices of honey, those for wooden shipping cases have kept to high levels. Tin-can prices have declined somewhat more than other bee sup-

Purchasing Power of a 10-Frame Hive in Pounds of Orange and Alfalfa Honey, 1910-1932

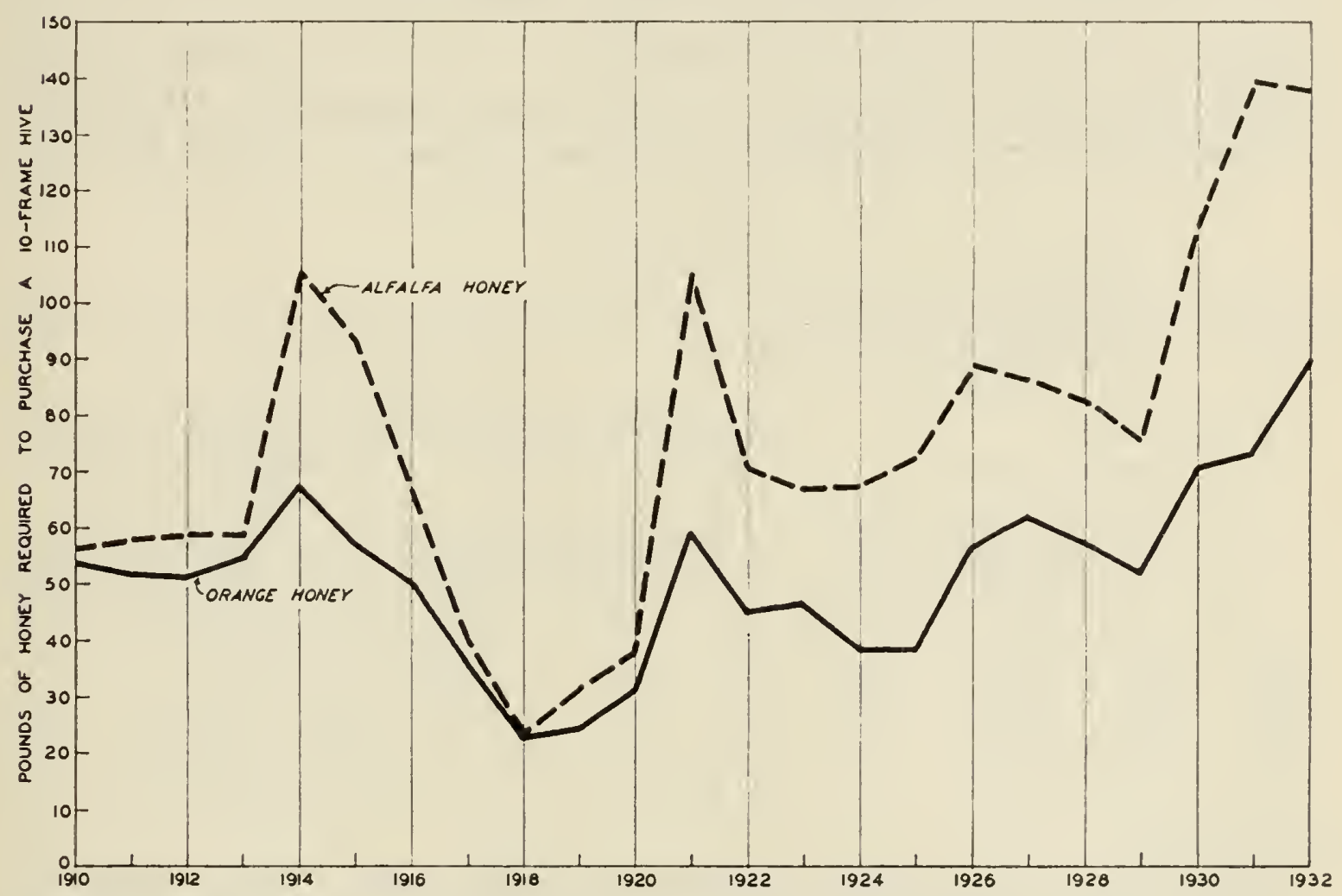

Fig. 29.-Since 1918 there has been an unfavorable trend in the relation between the prices of items purchased by the beekeeper and the prices of the product which he sells. The above graph distinctly indicates that an increasing amount of honey has been required to equal in value a 10 -frame hive. The producer of the lower-priced honeys has been in even a more unfavorable situation than the producer of high-priced honey.

plies, but, on a relative basis, remain above those of honey. ${ }^{87}$ Data from can-manufacturing companies and bee supply houses indicate that the 1932 prices were lower than those prevailing in pre-war years. However. relative honey prices also based upon pre-war years declined to a greater extent than those of tin cans in the years 1930-1932.

87 Prices of tin cans fell continuously from 1919 through 1932. Wholesale-price data furnished by two large can companies show the relative wholesale prices from 1925 through 1932 to be as follows: $1925=107 ; 1926=100 ; 1927=99$; $1928=93 ; 1929=90 ; 1930=89 ; 1931=87 ; 1932=85$. 


\section{TURNOVER IN THE BEE INDUSTRY}

Considerable interest has been manifest concerning the turnover in the personnel of the bee industry. In an examination of apiary registration statistics of 1928-1931 for San Diego, Los Angeles, Fresno, and Colusa counties ${ }^{88}$ a surprisingly large number entered and left the business. By far the larger in-and-out movement occurs among persons owning fewer than 100 colonies (table 31 ) and especially among those with less than 20 colonies. This in-and-out movement indicates that in

\section{TABLE 31}

Beekeepers Registered and Percentage Dropped and Added in Colusa, Fresno, Los Angetes, and San Diego Counties, 1928-1931

\begin{tabular}{|c|c|c|c|c|c|c|c|c|c|}
\hline \multirow{2}{*}{ Year } & \multicolumn{3}{|c|}{ Beekeepers registered } & \multicolumn{3}{|c|}{$\begin{array}{l}\text { Per cent of total number of } \\
\text { beekeepers dropped }\end{array}$} & \multicolumn{3}{|c|}{$\begin{array}{l}\text { Per cent of total number of } \\
\text { beekeepers added }\end{array}$} \\
\hline & Total & $\begin{array}{l}\text { With less } \\
\text { than } 100 \\
\text { colonies }\end{array}$ & $\begin{array}{l}\text { With } 100 \\
\text { or more } \\
\text { colonies }\end{array}$ & Total & $\begin{array}{l}\text { With less } \\
\text { than } 100 \\
\text { colonies }\end{array}$ & $\begin{array}{l}\text { With } 100 \\
\text { or more } \\
\text { colonies }\end{array}$ & Total & $\begin{array}{l}\text { With less } \\
\text { than } 100 \\
\text { colonies }\end{array}$ & $\begin{array}{l}\text { With } 100 \\
\text { or more } \\
\text { colonies }\end{array}$ \\
\hline 1928 & 2,491 & 2,248 & 243 & 19.6 & 18.8 & 0.8 & ......... & ......... & ......... \\
\hline 1929 & 2,834 & 2,605 & 229 & 28.7 & 27.9 & 0.8 & 29.3 & 28.3 & 1.0 \\
\hline 1930 & 2,619 & 2,398 & 221 & 19.1 & 18.1 & 1.0 & 22.9 & 21.9 & 1.0 \\
\hline 1931 & 2,747 & 2,516 & 231 & $\ldots \ldots .$. & ......... & ........ & 22.9 & 22.1 & 0.8 \\
\hline
\end{tabular}

Sources of data:

Compilations by George J. Brown, County Inspector of A piaries, Fresno County; Henry Perkins, County Inspector of Apiaries, Los Angeles County; Fred Hanson, County Inspector of Apiaries, San Diego County; and the authors.

far too few cases is the honey business studied carefully in advance, before embarking upon the enterprise.

The movement among the persons with over 100 colonies is from onehalf to one-third that prevailing among those with a lesser number. The former class naturally would contain those more largely dependent upon the industry for an income. Among the smaller operators will be found those largely interested in the use to which bees can be put for pollination purposes, as well as those who are starting an enterprise, together with many urban enthusiasts.

Examination of the registration statistics for the above-mentioned counties tends partially to confirm the impression held by a number of operators that there has been a decrease in total enterprises in the state over the past few years. In the years studied the actual and relative number of those with over 100 colonies leaving the industry has in-

88 The authors recoived the assistance of the following county inspectors of apiaries in making this phase of the study: Fred Hanson, San Diego County; Henry Perkins, Los Angeles County; and George J. Brown, Fresno County. 
creased while those entering has decreased. There was a slight increase in the total number of those with over 100 colonies in 19:31, which can be explained as being the number who had less than 100 colonies during one year and over 100 during the next.

The comparative stability of the bee industry in California is attested to by replies to the question "In what year did you first practice bee-

\section{TABLE 32}

A verage (Median) Number of Yhars in Bee Culture Industro as RePORTED By 212 OPERATORS

\begin{tabular}{|c|c|c|}
\hline Helt & $\begin{array}{l}\text { Number of } \\
\text { replies }\end{array}$ & $\begin{array}{l}\text { Average } \\
\text { number of } \\
\text { years in } \\
\text { business }\end{array}$ \\
\hline 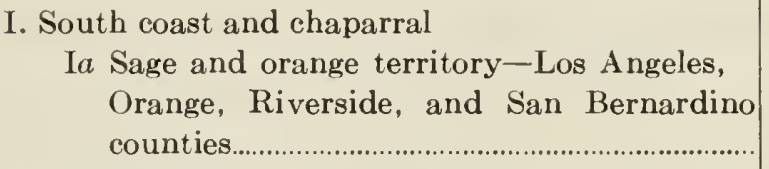 & \multirow{3}{*}{$\begin{array}{l}75 \\
45\end{array}$} & \multirow{2}{*}{$\begin{array}{l}14 \\
15\end{array}$} \\
\hline $\begin{array}{l}\text { Ib Sage-San Diego and Ventura counties....... } \\
\text { Ic Sage-Santa Barbara, San Luis Obispo, and }\end{array}$ & & \\
\hline II. Sacramento-San Joaquin & & 29 \\
\hline II $a$ San Joaquin Valley & \multirow{3}{*}{$\begin{array}{l}36 \\
32 \\
13\end{array}$} & 20 \\
\hline 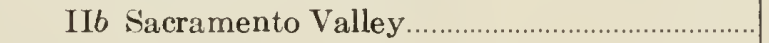 & & 21 \\
\hline III. Transmountain & & 20 \\
\hline $\begin{array}{l}\text { IV. Bay region and cut-over redwood area of the } \\
\text { Coast Range }\end{array}$ & 3 & 14 \\
\hline 'Total .. & 212 & 16 \\
\hline
\end{tabular}

Source of data:

Calculations by authors based on questionnaires returned by producers.

keeping?" The authors received 212 answers from all sections of the state. Only those records were used which definitely indicated the time during which the person had been in business in California. The average (median) number of colonies per enterprise was 135 . The length of time during which these persons had been in business was strikingly uniform in certain districts. The average (median) was slightly over sixteen years (table 32 ).

While these data do not in themselves give an exact picture of the length of time beekeepers remain in business, since a great many will continue their enterprises for years to come, they nevertheless point to the fact that a large number do make the industry part of their life work. 


\section{LOSS OF COLONIES IN CALIFORNIA}

Loss of colonies is an important consideration in the honey enterprise; it affects honey supplies, production costs, and the income of producers. Colony losses may be recouped with swarm or package bees, but when they are heavy over a considerable area, honey supplies may be affected for several seasons.

Colony losses may be classified under three general headings: spring and winter loss, disease, and miscellaneous causes. Comparison of the distribution of losses during the period 1915-1917 with that of 19291931 shows that while progress has been made in overcoming disease, losses from other causes lave changed but little (table 33 ).

TABLE 33

Percentage Distribution of Loss of Colonies in California, 1915-1917; 1929-1931

\begin{tabular}{|c|c|c|c|c|}
\hline Year & Disease & $\begin{array}{c}\text { Spring and } \\
\text { winter losses }\end{array}$ & $\begin{array}{l}\text { Unknown and } \\
\text { miscellaneous }\end{array}$ & Total \\
\hline \multicolumn{5}{|l|}{3 years 1915-1917 } \\
\hline $1915 \ldots$ & 5.7 & 2.9 & 0.9 & 9.5 \\
\hline $1916 \ldots \ldots \ldots$ & 7.0 & 5.3 & 1.0 & 13.3 \\
\hline $1917 \ldots \ldots \ldots \ldots$ & 9.8 & 61 & 0.4 & 16.3 \\
\hline \multicolumn{5}{|l|}{3 years $1929-1931$} \\
\hline $1929 \ldots \ldots \ldots \ldots \ldots$ & 2.5 & 6.9 & 18 & 112 \\
\hline 1930 & 1.5 & 46 & 1.0 & 71 \\
\hline $1931 \ldots \ldots \ldots \ldots \ldots \ldots \ldots \ldots$ & 1.4 & 6.0 & 2.5 & 9.9 \\
\hline
\end{tabular}

Sources of data:

1915-1917: Jones, S. A. Honey bees and homey production in the United States. U. S. Dept. Agr. Dept. Bul. 685: 14-20. 1918.

1929: Todd, Frank E. A piary inspection. California State Dept. Agr. Mo. Bul. 19:881. 1930

1930-1931: Unpublished data furnished through the California State Department of Agriculture.

Spring and Winter Losses. - These losses may be felt over wide areas. They are caused chiefly by starvation which results in poor honey flows, mseasonably long winter, or failure of spring honey flows. Along with other causes of losses, including robbing, weak colonies. loss or failure of queen, etc., they are largely preventable by careful management. The latter losses may entail considerable expenditure of time, effort, and expense. Winter losses in California vary considerably from year to year as indicated by the reports of the Bureau of Crop Estimates of the United States Department of Agriculture:

\begin{tabular}{|c|c|c|c|}
\hline & P'BR CWN'T & & PER CANT \\
\hline $1917-18$ & .. 11.0 & $1922-29$. & 7.0 \\
\hline $1918-19$ & 11.0 & $1923-24 \ldots$ & 18.0 \\
\hline $1919-20$ & 11.0 & $1924-25 \ldots$ & 12.0 \\
\hline $1920-21$ & 7.0 & 11 year average... & 10.0 \\
\hline $921-26$ & 10.0 & & \\
\hline
\end{tabular}


Disease.-No economic study of the honey industry in California would be complete without some reference to disease. The chief diseases of bees are American and European foulbrood, both of which kill the immature bees before they emerge from their cells. These two diseases reduce productive capacity of the colony or kill it outright. They are infectious in nature and are readily identified by experienced beekeepers from the gross symptoms ${ }^{89}$ in field examinations.

During 1910-1914 California experienced a general epidemic of European foulbrood which killed many thousands of colonies of bees. 'The general stock in California at that time was the German black race, highly susceptible to this disease. This epidemic resulted in the restocking of California with the Italian race which has proved to be more resistant to European foulbrood. While this disease is still troublesome in several localities and during certain periods weakens colonies, the resistance of Italian stock has largely prevented the killing of colonies, and the disease is not the serious factor that it once was.

'The infectious nature of American foulbrood ${ }^{90}$ is such that the beekeeper is helpless to protect his property from it if it exists in his neighborhood. In order to give this property protection most states have bee-inspection laws. California has had such laws since 1883.

Under California laws two methods of approaching the American foulbrood problem have been tried: The control method (1901-1927) consisted of separating bees from the infected material in the hive and placing them on beeswax foundation. Infected combs are then destroyed by boiling, the wax being salvaged. This method necessitated the purchase of foundation and occasioned considerable labor. Since by this method the disease is not usually eradicated from the apiary, the procedure is repeated annually. The eradication method (1927-1932) required the killing of bees and the burning of the hive contents, the hive being salvaged. From an economic standpoint, the first cost involved in the eradication method is usually the last one. Most of the beekeepers of California believe the progress made toward the elimination of disease justifies this method, which is recommended by the United States Department of Agriculture.

89 Todd, Frank E. Bee disease in California. California State Dept. Agr. Mo. Bul. 17:192-199. 1928; 18:16-34. 1929 .

Laboratory diagnosis can be obtained free from the United States Bee Culture Field Laboratory, or the California state Department of Agrieulture.

90 American foulbrood was introduced into eastern United States at a very carly date and thence into California in 1857. It is widely distributed over the country. 
The California Apiar'y Inspection $\Lambda \mathrm{ct}^{91}$ was passed in 1927 at which time approximately 10 per cent of the colonies in the state were diseased. During the five-year period 1928-1932 the percentage of diseased colonies in California was reduced from 5.0 to 1.28 while the number of infected apiaries was reduced from 40.0 to 12.6 per cent. ${ }^{92}$ These results are attributable to the application of eradication methods.

In the course of another economic survey, it was found to be the consensus of opinion among producers that they could care for double the number of colonies if they were disease free. It would seem, therefore, that the progress made towards disease eradication has increased the efficiency of California beekeepers, and reduced production costs. Those familiar with the situation believe that this disease can be practically eliminated from California by pursuing the system provided by the present law.

Miscellaneous losses are usually the result of fire (grass and forest), flood, theft, bears, skunks, mice, spray poison, or buckeye poison. Losses of this type are usually local in extent and variable from year to year. They are to a considerable extent preventable and probably have less effect on honey supplies than other causes of loss.

91 The first California bee-inspection act was passed in 1883, providing for county option in appointment of inspectors and for destroying of diseased colonies. This act was amended in 1901 to permit use of control measures and the results proved to be unsatisfactory. The 1927 act provided for eradication methods and state-wide enforcement administered by the California State Department of Agriculture.

92 See Todd, Frauk E. Apiary inspection. California State Dept. Agr. Mo. Bul. 19:892. 1930.

Krebs, H. M. California State Dept. Agr., Ann. Rept. 1931:760. 1931.

Krebs, H. M. Ann. Rept. Supervisor of apiary iuspection. California State Dept. Agr. 1932. (Mimeo.) 


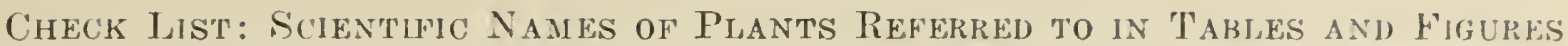

\begin{tabular}{|c|c|c|c|}
\hline Comnon name & Genus and species & Common name & Genus and species \\
\hline Agastache. & Agastache urticifolia (Benth.) & Maple, & Acer circinatum P'ursh. \\
\hline & Ktze & Melon. & Cucumis spp. \\
\hline Alfalfa & Medicago sativa I. & Mesquite, honey... & Prosopis juliflora DC. \\
\hline garc & pis juliflora DC. & & \\
\hline Alsike clover & Trifolium hybridum I. & Milkweed & Asclepias syriaca I.. \\
\hline Amelai & Amelanchier alnifolia Nutt. & Milkwort. & Polygala cornuta Kell. \\
\hline Arrow & Pluchea sericea (Nutt.) Cov. & Mistletoe.. & Phoradendron: \\
\hline Aster. & Aster spp. & Mustard & Brassica spp. \\
\hline Athel & Tamarix articulata Vahl. & Orange.... & Citrus aurantium I. \\
\hline Basswood & Tilia americana L. & Oregon maple. & Acer macrophyllum Pursh. \\
\hline Bear clover. & Chamaebatia foliolosa Benth. & Partridge pea & Cassia chamaec \\
\hline Black locust. & Robinia pseudacacia L. & Pers & Diospyros virginiana I. \\
\hline Blue o & TrichostemalanceolatumBenth. & Pois & Rhus diversiloba T. \& G. \\
\hline Blue $g$ & Eucalyptus globulus Labill. & Rabbit brush & Chrysothamnus n \\
\hline Buckeye, California & A esculus californica Nutt. & & $(\mathrm{Pa}$ \\
\hline $\mathrm{Bu}$ & & $\operatorname{Red}$ & Eucalyptus rostratu serlileclit \\
\hline ad & $\begin{array}{l}\text { Fagopurum exculentum } \\
\text { Moench. }\end{array}$ & $\begin{array}{l}\text { Red cascara .......... } \\
\text { Red clover............. }\end{array}$ & $\begin{array}{l}\text { Rhammus rubra Creene } \\
\text { Trifolium pratense L. }\end{array}$ \\
\hline Bush lima......... & Phaseolus limensis Marf. & Royal palm. Puert & \\
\hline & $r^{l}$ & & Roystonea borinquena $\mathrm{O} . \mathrm{F}$. \\
\hline to. & $\begin{array}{l}\text { Cephalanthus occidentulis: } \mathrm{I} \text {. } \\
\text { Sabal palmetto lodd. }\end{array}$ & Sage & Salin spp. \\
\hline a buckeye & Aesculus califormica Nutt. & Sage, black & Saliza mellifern Gireene \\
\hline Cam & $1 p o$ & Nis & Salvia sonomensis Greene \\
\hline Cascara & iformica Escll. & Sag & Salria lencophylla Greenc \\
\hline Catc & $i$ Gray & Sag & Salvia amiana.J \\
\hline Ceda & Libocedru & $\therefore a$ & Serenoa serrulata Hook. \\
\hline Chi & $\begin{array}{l}\text { Castanopsis sempcrirens: } \\
\text { Dudley }\end{array}$ & $\begin{array}{l}\text { Scrub palmetto } \\
\text { Service berry...... }\end{array}$ & $\begin{array}{l}\text { Sabal megacarpa Small } \\
\text { Amelanchier alnifolia Nutt. }\end{array}$ \\
\hline Chr & Photinia arbutifolia Iindl. & Snowberry & Symphoricarpos albus (1..) \\
\hline $\mathrm{Cla}$ & Clarkia spp. & & $\mathrm{BI}$ \\
\hline ry & lifornica Esch. & Soap plan & Chlorogalum pomeridianum \\
\hline $\mathrm{C}$ & Go & & \\
\hline $\mathrm{Coy}$ & osa Bentl & Sou & Oxydendrum arboreum. (L.) DC \\
\hline Dar & Tar & Spikeweed & Centromadia mungens (T. \& \\
\hline Dee & grrimus H.\&A. & & $\mathrm{G}$ \\
\hline Elm.. & Ulmu & Spanish needle & Bidens aristosa (Michx.) Brit- \\
\hline Eri & Erio & & \\
\hline Euc & Euc & Sta & Centaurea solstitialis L. \\
\hline Fig & hulariacalifo & Sul & $R h e$ \\
\hline Filare & L'Her. & er, white & Melilotus alba Desr. \\
\hline em. & m I'Her. & ver, yellow & Melilotus officinalis Jam. \\
\hline Fir & stifolium L. & Tam & Tamarix articulata Vahl. \\
\hline $\mathrm{Ga}$ & Ilex & Tar & Hemizonia spp. \\
\hline Gian & Agastache urticifolia Benth. & Titi.......... & Cliftonia monophylla Sarg. \\
\hline Golc & Solidago spp. & Toyo & Photinia arbutifolia Lindl. \\
\hline $\mathrm{He}$ & persicaria $\mathrm{L}$. & Tulip tree.. & Liriodendron tulipifera I. \\
\hline mericar & Ilex opaca Ait. & Tupelo, gu & Nyssa spp. \\
\hline Ho & Monarda $p$ & Vetch. & Vicia spp. \\
\hline Huajillo........... & Acacia berlandieri Benth. & Vine maple... & Acer circinatum Pursh. \\
\hline Jackass elover & Wislizenia refracta Engelm. & White elover & Trifolium repens $\mathrm{L}$. \\
\hline $\mathrm{Li}$ & Phaseolus limensis Macf. & Wil & Salix spp. \\
\hline Lippia. & Lippia spp. & Wild alfalfa....... & Lotus scoparius (Nutt.) Ottley \\
\hline Logwood.. & $\begin{array}{l}\text { Haematoxylon campechianum } \\
\text { L. }\end{array}$ & $\begin{array}{l}\text { Wild buckwheat } \\
\text { Wild cherry........... }\end{array}$ & $\begin{array}{l}\text { Eriogonumfasciculatum Benth. } \\
\text { Prunus spp. }\end{array}$ \\
\hline Lot & Lotus spp. & Wild onion..... & Allium spp. \\
\hline e. black & Avicennia nitida Jacq. & Wild & Prunus spp. \\
\hline Manzanita & Arctostaphylos spp. & Yerba santa.. & Eriodictyon californicum ( \\
\hline Maple... & Acer spp. & & \& A.) Greene \\
\hline Maple, Oregon & Acer macrophyllum Pursh. & & \\
\hline
\end{tabular}




\section{ACKNOWLEDGMENTS}

Credit is due to Messr's. E. L. Sechrist and G. H. Vansell, Associate Apiculturists in the Pacific States Bee Culture Field Laboratory of the United States Department of Agriculture, for their helpful advice and constructive eriticism in the conduct of this study and preparation of the manuseript.

Special acknowledgment is due to Professor A. W. Sampson, Forest Ecologist in the Agricultural Experiment Station of the University of California, for his advice and assistance in connection with the bee ranges of the Sierra Nevada Mountains.

The Bureau of Entomology of the United States Department of Agriculture, the Bureau of Agricultural Economies, and the Federal-State Market News Service assisted in obtaining the necessary information.

The County Bee Inspectors not only assisted the authors in making field contacts with individual producers, but, in addition, they furnished the essential information underlying the section on the turnover in the honey business.

Ahmost three hundred individual beekeepers in California coöperated with the authors by furnishing information, without which the publication wonld have obtained but little of interest to the industry.

'The firms handling honey and those buying and selling beeswax furnished data, which have not only served as a check on other information obtained, but, in addition, have provided information of a type not readily available.

Data and assistance in compiling the material on honey-flows in various parts of the state were liberally contributed by the following:

William Atchley, Beekeeper, San Bernardino County; C. F. Anstin, Beekeeper, Imperial County; Roy K. Bishop, Bee Inspector, Orange County; George J. Brown, Bee Inspector, Fresno County; Walter Callison, Bee Inspector, 'Tulare County; 'Thomas Chalmers, County Agricultural Commissioner, San Luis Obispo County; J. Connolly (deceased), formerly Bee Inspector, Yolo County; A. Dickenson, Beekeeper, Napa County; George T. Edwards, Beekeeper, Imperial County; L. G. Goar, Field Assistant in Agronomy, University of California, Davis; Fred Hauson, Bee Inspector, San Diego County; Cary W. Hartman, Secretary, California Beekeepers' Association; 'T. C. Hawley, formerly Bee Inspector, Madera County; R. I. Hough, Paso Robles Almond Growers' Association, Paso Robles; Leon Jaequemine, Bee Inspector, Monterey County; R. E. La Barre, Beekeeper, Shasta County; Albert Lubkin, 
Bee Inspector, Inyo County; Charles H. Manville, Beekeeper, Colusa County; R. C. Marks, Bee Inspector, Ventura County; W. C. Miles, Beekeeper, San Bernardino County; George W. Moore, formerly Bee Inspector, Contra Costa County; T. O. Nicholaysen, Beekeeper, Stanislaus County; A. Norton (deceased), formerly Bee Inspector, Monterey County; Henry Perkins, Bee Inspector, Los Angeles County; M. J. Sain, Bee Inspector, Kings County; C. R. Snyder, Beekeeper, Fresno County; R. A. Tait (deceased), formerly Bee Inspector, Siskiyou County; W. W. Thompson (deceased), formerly Bee Inspector, Merced County; George II. Vansell, Associate Apiculturist, Pacific Coast Bee Culture Laboratory, Davis; S. Van Wye, Beekeeper, Stanislaus County; William G. Watkins, Bee Inspector, El Dorado County; H. L. Weems, President. California Beekeepers' Association, Kern County; William E. Wright, Bee Inspector, Butte County; Carl Wurth, Bee Inspector, Riverside County. 
